\title{
INSECTS OF ECONOMIC IMPORTANCE
}

\section{GLENN W. HERRICK}




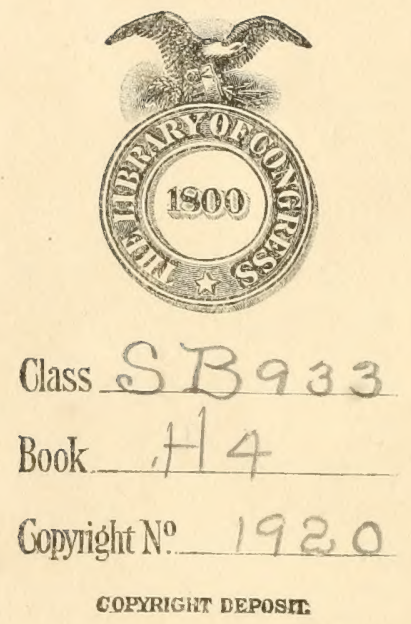




INSECTS OF ECONOMIC IMPORTANCE 


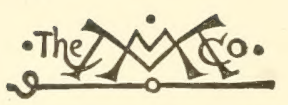

THE MACMILLAN COMPANY

NEW YORK - BOSTON - CHICAGO - DALLAS

ATLANTA - SAN FRANCISCO

MACMILLAN \& CO., Limitid

LONDON - BOMBAY - CALCUTIA

MELBOURNE

THE MACMILLAN CO. OF CANADA, LtD. TORONTO 


\title{
INSECTS OF ECONOMIC IMPORTANCE
}

\author{
Outlines of Lectures in Economic \\ Entomologv
}

\author{
BY \\ GLENN W. HERRICK \\ Professor of Economic Entomology, Cornell University
}

New and Revised Edition

NEW YORK, N. Y.

THE MACMILLAN COMPANY

1920 


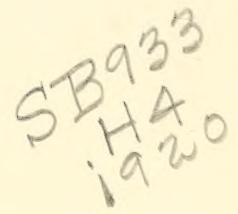

\section{COPYRIGHT 1915 AND 1920 \\ By THE MACMILLAN COMPANY}

New and Revised Edition. Published, May, 1920

\section{JUL 171920}

(C) A. A 570754 


\section{PREFACE}

Not all insects of economic importance are included in these outlines. To discuss them all, a book many times the size of this would be needed. However, the principal pests of our important fruits, vegetables, cereals, farm animals, shadetrees, and of the household are discussed. A brief summary of the life habits of each, so far as they are known, is made, and the latest methods of control are outlined. In addition, a concise discussion of insecticides is given together with formulæ and directions for making and applying them.

Since the first edition of these outlines was published important advances have been made in our knowledge of the habits and control of many insect pests. Therefore, in this new edition some changes in the text and many additions to it have been made in an attempt to bring it down to date.

As in the previous edition, references are again given to the more important sources of information regarding the insects and their control. As far as possible, references are made to bulletins available to the general student and to those publications giving faithful illustrations of the insects, together with the most approved methods of control. 



\section{CONTENTS}

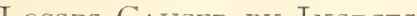

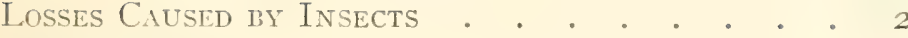
Useful Insects . . . . . . . . . . . 4 Entomological Literature . . . . . . . . 6 Natural Methods of Insect Control . . . . 8 Artificinl Methods of Insect Control . . . . io Poison Insecticides . . . . . . . . . . I I Poison Batts . . . . . . . . . . . . I7 Contact Insecticides . . . . . . . . . . . i8 Fumigating Substances . . . . . . . . 27

Miscellaneous Means of Insect Control . . . 29 D) Quarantine and Insecticide Laws . . . . 33 Insects Injurious to Orcinard Trees and Fruits • 36 Insects Injurious to Small Fruits . . . . 7 i Insects Injurious to Vegetadles . . . . . 88 Insects Injurious to Hors . . . . . . . . iog Insects Injurious to Тов $\Lambda$ CCO . . . . . . II2 Insects Injurious to Cereal Crops . . . . II4 Clover and Alfalfa Pests . . . . . . . . I23 Cotton Pests . . . . . . . . . . . . 127 Insects Injurious to Stored Griln . . . . . izo Insects Injurious to Greenhouse Plants . . . I3I Insects Injurious to Shade Trees . . . . . I37 Insects Injurious to Farm Animals . . . . I44 External Parasites of Poultry . . . . . . I53 Ixsects Injurious to time Houseitold . . . . I58 



\section{INSECTS OF ECONOMIC IMPOR'TANCE}

The science of economic entomology has made rapid progress during the last twenty years. It has advanced astonishingly in the number of persons engaged in the study of insects for the purpose of preventing their ravages, in developing and perfecting mixtures for repelling and killing insects, in devising effective apparatus for applying insecticides, and in determining more exact methods of preventing the losses caused by these persistent pests. The following outlines of lectures are intended to cover, as far as is possible in a brief, general course, the different phases of the subject of economic entomology as it exists to-day.

\section{OBJECTS OF THE COURSE}

(a) To become acquainted with the common insect pests and with their habits and life histories in order that they may be fought intelligently.

(b) To become acquainted with the modern and most practical methods of fighting insect pests.

\section{TWO PHASES OF ENTOMOLOGY}

(a) The pure science of entomology.

(b) The economic or science applied of entomology.

The pure science of entomology is a study of the kinds of insects together with their relationships to 
each other, their structure, habits, and transformations. It is a work of rescarch and pleasure and forms the basis of economic entomology.

Fconomic entomology is research on the life histories and habits of injurious insects and the determination of some method whereby their ravages may be avoided or controlled.

\section{LOSSES CAUSED BY INSECTS}

The losses catised by insects in the United States alone are estimated to aggregate more than a billion dollars annually. ${ }^{1}$

The value of the different crops and products produced in Igon in the United States is given in round numbers in the following table, the figures being taken mainly from the census of IgIo. The losses by insect pests are estimated to be at least IO $\%$ of the value of these products and in two cases at least $20 \%$.

\begin{tabular}{|c|c|}
\hline Product & Talue in 1909 \\
\hline Cereals & $2,600,000,000$ \\
\hline er grains and secds & $97,000,000$ \\
\hline and forage....... & $\mathrm{OOO}, \mathrm{COC}$ \\
\hline acco & 00,000 \\
\hline$n$ and seed & 825 \\
\hline$r$ crops. & $62,000,000$ \\
\hline$r$ crops. & 000 \\
\hline tables ....... & 00,000 \\
\hline 8 and nuts.... & $222,000,000$ \\
\hline ers and plants. & $35,000,000$ \\
\hline sery products & $21,000,000$ \\
\hline forests...$\ldots \ldots$ & $195,000,000$ \\
\hline mal products .. & $3,000,000,00$ \\
\hline $\begin{array}{l}\text { rests } \ldots . . . . . . . \\
\text { ored prodiucts .... }\end{array}$ & \\
\hline
\end{tabular}

Percentage of
loss by insects
10
I0
I0
I0
10
10
10
20
20
10
10
10
10
10
10

Total loss by insects $\$ 260,000,000$

$0,700,000$ $82,400,000$ $10,400,000$ $82,500,000$ $6,200,000$ $1,800,000$ $83,600,000$ $44,400,000$ $3,500,000$ $2,100,000$ $10,500,000$ $300,000,000$ 2 100,000.000 ${ }^{3} 200,000,000$

$\$ 1,206,100,000$ Quaintance estimates the annual loss to the de1 Marlatt-Jr. Ec. Ent., Vol. 4, p. I09.

2 Hopkins-U. S. Bu. Ent., Bull. 5\&, Pt. 5.

3 Estimated. 
ciduous fruit interests of the United States as over $\$ 66,000,000$.

The annual loss to the people of the United States from malarial diseases carried hy mosquitoes is not less than $\$ 100,000,000 . *$ The loss to agriculture and other industries as a result of malaria is enormous. ${ }^{5}$

The loss that has been caused by yellow ferer, carried only by mosquitoes, cannot now be estimated but was certainly very great.

Typhoid fever, due in large measure, at least, to its dissemination by the house-fly, causes a very great annual monetary loss.

The Mexican cotton-boll weevil costs Texas at least $\$ 25,000,000$ annually, and it is estimated that when it spreads over the whole cotton area it will cause a yearly loss of $\$ 250,000,000$.

The Hessian wheat-fly in rgoo cost the wheat grovers \$IO0,000,000.

The chinch bug during the period from $I_{5}$ o to IoOo caused a loss estimated as probably in excess of $\$ 350,000,000 .^{6}$

The codling moth causes the fruit growers of the U. S. a loss of over \$I2,000,000 and of New York, alone, more than $\$ 3,000,000$ annually.

\section{COST OF FIGH'TING INSEC'TS}

To the destruction occasioned by insects must be added the cost of fighting them.

It is estimated that it costs $\$ 4,000,000$ to spray the apple trees in the United States for the codling moth.

It is said that it costs $\$ I 0,000,000$ annually to spray for the San José scale.

${ }^{4}$ Howard-U. S. Bu. Ent., Bull. 78.

5 Herrick-Popular Science Monthly, April, 1903.

6 Weloster-U. S. Bu. Ent., Circ. II3. 
It costs $\$ 10,000,000$ to screen against the houseAy.

The New England States and the Federal Government have already spent over $\$ 10,000,000$ in fighting the gypsy and brown-tail moths and at the present time are spending fully $\$ \mathrm{I}, \mathrm{OOO}, \mathrm{OOO}$ per annum.

\section{OUR INSECT FOES ARE INCREASING}

Insect pests are coming from foreign countriesSan José scale, gypsy moth, Mexican cotton-boll weevil, and many others-unaccompanied by natural checks. ${ }^{7}$

Out of 73 of our worst pests, at least 37 or over half have been imported from foreign countries.

Insects once harmless become serious pests owing to changed conditions-Colorado potato beetle, blister-mite, redbugs, et al. ${ }^{8}$

Happily, not all insects are injurious; many of them are beneficial.

\section{USEFUL INSECT'S}

Silk-worms furnish material for clothing.

Scale insects produce a waxy material from which shellac is made. Shellac is used in paints and varnishes and in making inks, gramophone records, jewelry settings, etc. ${ }^{9}$ The pulverized bodies of certain species furnish cochineal.

The census of IOIO reports $3,445,006$ colonies of bees in the United States valued at \$10,373.615. The value of the honey and wax produced was nearly $\$ 6,000,000$. Bees also aid in the cross-pol-

7 Howard-U. S. Dept. Agri., Yearbook 1897, p. 529.

8 Herrick-Cornell Countryman, I9I0, Vol. 8, No. 2, p. 28.

${ }^{9}$ Comstock-U. S. Ent., Report for I880. 
lination of flowers. Bumblebees perform a notable service in cross-pollinating clover. ${ }^{10}$

The Blastophaga, a minute wasp-like insect, cross-pollinates the cultivated and wild fig, thus making possible the production of the Smyrna fig in California. ${ }^{11}$

\section{PREDACEOUS INSEC'TS}

Many species of insects catch and devour other species for food. These are known as predaceous insects and they are of immense value in aiding man in the fight against his insect foes. ${ }^{12}$

The ladybird beetles are probably the most important. There are several species, the two-spotted ladybird (Adalia bifunctata), the twice stabbed ladybird (Chilocorus bialuerus), the convergent ladybird (Hippodamia conzergens), and other species.

Many larva of a family of flies, the Syrphida, perform great benefit in destroying plant lice.

The ground-beetles (Carabide) are exceedingly beneficial in destroying insects that are found 1 pon or in the soil.

Other beetles, flies, wasps, and certain bugs, contribute to the good work.

\section{PARASITIC INSECTS}

There are many insects that live upon or within the eggs or bodies of other insects and derive the nourishment necessary for their growth from their living hosts. These are called parasitic insects and are among the best natural checks of insect pests. ${ }^{1.3}$

10 Waldron-Report of North Dakota Sub-Expt. Sta., at Dickinson, I908.

11 Howard-U. S. Dept. Agri., Yearbook I900, p. 79.

12 Smith-Insect Friends and Foes.

13 Webster-U. S. Dept. Agri., Yearbook for I907, p. 237. 
One of the interesting and effective groups of parasitic insects is the tachinid flies (FamilyTaclinida).

Probably the greatest number of parasites is found in the order Hymenoptera. For example, the ichnemmon-flies, braconid-flies, chalcis-flies and the proctotrypid-flies.

\section{ENTOMOLOGICAL IITERATURE}

No one volume could contain descriptions of al: insects.

Fifty thousand or more described species from N. A.

Descriptions and life histories would fill I5O volumes.

\section{OUR MAIN SOURCES OF INFORMATION}

I. Bulletins of the different state experiment stations throughout the United States.

2. Bulletins of the U. S. Bureau of Entomology, Washington, D. C.

3. Farmers' Bulletins of the U. S. Dept. Agriculture, Washington, D. C.

4. Yearbooks of the U. S. Department of Agriculture, Washington, D. C.

5. In New York State the bulletins of the State Entomologist, Education Ruilding, Allany, N. Y.; the bulletins of the State Experinent Station. Geneva, N. Y.; and the bulletins of the Cornell Unirersity Experiment Station are available sonrces of information.

\section{SOME BOOKS}

Manual of Fruit Insects, by M. V. Slingerland and C. R. Crosby, Macmillan Co. 
Insect Pests of Farm, Garden and Orchard, by E. D. Sanderson, John Wiley \& Sons.

Insects injurious to Vegetables, by F. H. Chittenden, Orange Judd Co.

Manual of Vegetable Insects, by C. R. Crosby and M. D. Leonard, Macmillan Co.

Insects and Insecticides, by C. M. Weed, Orange Judd Co.

Economic Entomology, by J. T. Smith, J. T. Lippincott Co.

Insects Injurious to the Household and Annoying to Man, by Glenn W. Herrick, Macmillan Co.

Manual for the Study of Insects, by J. H. Comstock, Comstock Pub. Co.

\section{NUMBER OF INSECTS}

Over. 350,000 now known and described. Estimated to be from two to ten millions. Over 50,000 from North America. Several thousand are being described each year.

GROLPS CONTAINING THE PRINCIPAL INJURIOUS INSECTS

I. Orthoptera-Crickets, grasshoppers, cockroaches, et al.

2. Hemiptora-aphids, scale insects, chinch bugs, et al.

3. Lepidopterab-butterflies and moths.

4. Diptera-flies.

5. Colcoptera-beetles.

6. Hymenoptera-sawflies, bees, ants, wasps, et al.

Again, all of the injurious insects may be gathered into two great groups, dependent upon the structure of their mouthparts. These are the sucking and biting insects. 
a. Sucking insects

These are represented by the aphids, bugs, and flies. The mouthparts are formed for piercing the plant and sucking out the juices.

b. Biting insects

These may be represented by the grasshoppers and beetles. The mouthparts are formed for biting off bits of the plants and chewing them.

\section{ME'THODS OF CONTROL OF INSEC'T PESTS}

Ideas and practices of ancient times and peoples.

Modern ideas and practices are based on two main methods: natural and artificial.

\section{Natural methods}

Hand-picking-tomato worms, tobacco worms, squash bugs.

Cutting out by hand-peach-tree borer, apple-tree borers.

Covering plants to protect them-cucumber beetles.

Hopper-dozers-for grasshoppers and leafhoppers.

Burlap and cotton bands-for canker-worms and codling moth.

Sticky bands-for canker-worms and gypsy moth.

Sticky shields-for leafhoppers.

Barrier method-for chinch bug and army worms.

Collecting eggs-gypsy moth and tent caterpillars.

Collecting larva-brown-tail moth.

Burning branches and trees-for shot-hole borer, bronze birch borer, twig girdler, raspberry canegirdler, et al. 
(leaning up) rubbish and weeds-for cabluase insects, cotton-boll weevil, plum curculio, et al.

Burning straw, leaves, and grass-for Hessian fly and chinch bugs.

Planting early-for cotton-boll weevil.

Planting late-for corn root-worm and Hessian fly and pea weevil.

Plowing in fall-for wire worms and for white grubs.

Rotating crops-for white grubs, for corn billbugs, and for many pests.

Resistant varieties of plants-Kieffer pear, American grape stocks, Northern Spy root-stocks.

Use of commercial fertilizers-very little if of any use directly. Of use in accelerating growth to hasten maturity and to make strong resistant plants. Phosphoric acid and cotton.

Refraining from planting badly infested crops for two or three years-chinch bugs and wheat, boll-weevil and cotton.

Isolating fields-For cotton-boll weevil, et al.

Mowing crops early-clover seed insects.

Protecting BrRDs-Birds should be protected and encouraged to make their homes on the farm and about the orchards. They help to hold the balance of nature and certainly aid greatly in holding insects in check.

One hawk after a chicken condemns the whole bird tribe; the great horned owl is a friend of man wherever mice and rabbits abound, but where these are scarce, as in thickly populated districts the owl is driven to other food; the sharp-shinned and cooper's hawk are enemies to wild birds and chickens and should he killed; other hawks and owls feed mostly on mice and insects; many species of birds are known to live almost wholly upon insects. Insects constitute $65 \%$ of the annual food supply 
of the downy woodpecker, a very large percent of the food of warblers, $95 \%$ of the food of the house wren, and $96 \%$ of the food of the flycatchers. Three hundred to five hundred insects have been found in the stomach of one bird.

The mobility of birds makes them very efficient. Forbes showed that in orchards where cankerworms were abundant birds became abnormally plentiful.

Flycatchers and swallows live upon flying insects, while rolins and meadowlarks catch ground insects. Cuckoos, orioles, warblers, and vireos devour leafeating insects while nuthatches, titmice, and creepers explore trunks of trees for small insects.

References on the work of birds:

Henshaw-U. S. Dept. Agri., yearbook i907, p. 165.

Beal-U. S. Dept. Agri., yearbook I908, p. 343. Sanderson-New Hamp. Expt. Sta., Ioth and 2oth Rpts., igos, p. 398.

Forbush-Useful Birds and their Protection.

INTRODUCTION OF PREDACEOUS INSECTS-Predaceous insects, especially ladybird beetles and certain ground beetles are sometimes introduced into a locality to prey upon injurious insects. For example, the Australian ladybird ( Tozins cardinalis), the ground beetle (Calosoma sycophanta), and the convergent ladybird (Hippodamia convergens).

INTRODUCTION OF PARASITIC INSECTS-Parasitic insects are introduced into one country from another to help in the fight against insect pests. For example, the many parasites introduced from Europe to prey upon the gypsy and brown-tail moths.

\section{Artificial methods}

Artificial methods consist mainly in the use of insecticides. 
The kind of insecticide used will depend upon the lind of mouthparts the pest has, whether liting or sucking:

It will also depend somewhat upon the life history and habits of the pest.

There are two main kinds of insecticides.-(a) Poisons for biting insects; (b) contact substances for sucking insects. Gases are also used for hoth biting and sucking insects.

\section{POISONS FOR BITING INSEC'TS}

Several forms of arsenical poisons are used for killing insects that eat the foliage of plants. Arsenate of lead, however, is more universally used in orchard work than any of the others. The following are some of the poisons employed:

I. White arsenic.

2. Paris green.

3. Arsenate of lead.

4. Arsenate of calcium.

5. Arsenite of zinc.

6. Arsenite of lime.

7. Arsenite of copper.

8. London purple.

9. Paragrene.

IO. Hellebore.

\section{Arsenic}

White arsenic $\left(\mathrm{As}_{2} \mathrm{O}_{3}\right)$ is a white heavy powder and the cheapest form of a poison insecticide. $U_{1 n-}$ fortunately, it is soluble in water and therefore will burn foliage. It can he used in combination with lime or Bordeatux mixture, howerer, if the proper precautions are taken.

In the following formulas the arsenic is combined with lime and the material is known as arsenite of lime. 


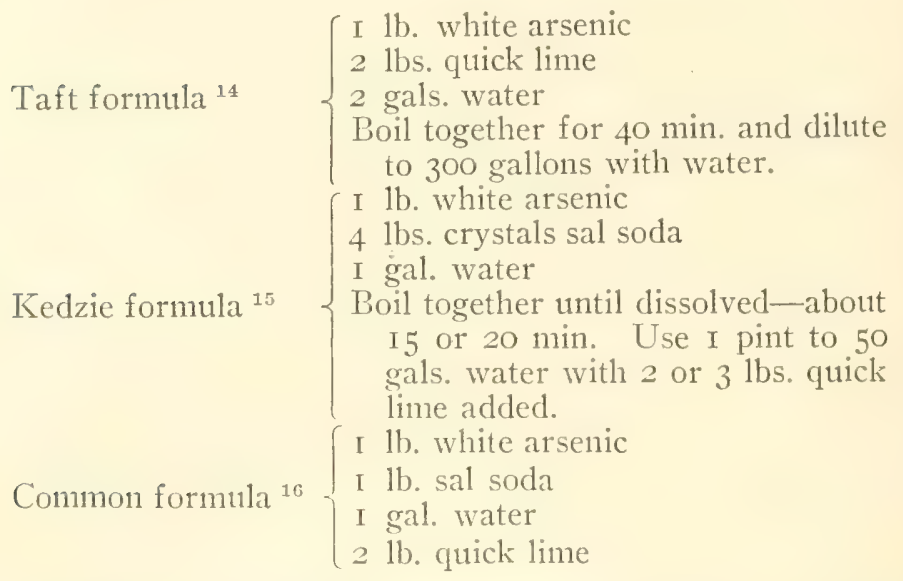

Dissolve the white arsenic and sal soda in the water by boiling all together in an iron vessel for about I 5 or 20 minutes. Use this solution while hot to slake the lime. Add enough water to make 2 gallons. Use 2 quarts of this to 50 gallons of water.

Another method of making arsenite of lime is to hoil I pound of white arsenic and + pounds of quick lime in 4 gallons of water for half an hour and then dilute to 200 gallons of water. The arsenic may not all combine with the lime thus causing burning: These combinations of arsenic and lime have not given satisfaction when used with limesulphur. ${ }^{17}$

\section{PARIS GREEN}

First used against Colorado potato beetle about I 868 ; 2000 to 3000 tons used every year ; it is com-

1; Woodworth and Colby-Calif. Expt. Stat, Bull. I26, p. 23.

15 Quaintance-U. S. Dept. Agri., Yearbook 1908, p. 275.

16 Slingerland, Herrick, Crosby-Cornell Univ. Expt. Stat., Bull. 283 , p. 476 .

17 Scott-U. S. But. Plt. Ind., Circ. 54, p. I4. 
posed of white arsenic, ${ }^{18}$ copper oxide, and acetic acid. When pure it consists of $58.65 \%$ arsenions oxide, 3I.20\%, copper oxicle, I0.06\% acetic acid. Not over $3 \frac{T}{2} \%$ should be soluble.

Paris green ${ }^{19}$ is a coarse powder and not easily held in suspension; it cannot be used on conifers; cannot be used with fungicides containing ammonia; cannot be combined with lime-sulphur with safety; does not adhere well to foliage. At least I pound of freshly slaked lime should be mixed with every pound of paris green to take up the soluble arsenic and prevent burning of the foliage or it should be combined with Pordeaux mixture.

\section{STANDARD FORMULAS}

Paris green......... oz. Paris green.......... $1 \mathrm{l}$. Outck lime.......... I 1b. Ouick lime......... Ibs. Water ..................... gals. Water........

Stewart recommends I pound of paris green per acre of potatoes whether 50 gallons or IOO gallons of Bordeaux are applied. If the poison is used in water alone then I or 2 pounds of quick lime should be slaked and added.

IMPURITIES AND TESTS FOR ${ }^{20}$-Paris green can be tested in three simple ways for impurities: I. Ammonia test. Paris green dissolves wholly in ammonia leaving no residue; 2. Glass slide test. Pure paris green jarred on a slide leaves a bright green streak. If impure the streak is whitish or pale green; 3. Microscopic test. Under the microscope the grains of paris green appear like clean round balls. The crystals of the impurities will appear angular, irregular and whitish.

18 Lodeman-Spraying of Plants, pp. 59-74.

19 Smith-New Jersey Expt. Stat., Bull. 2 I3.

20 Woodworth \& Colby-Calif. Expt. Stat., Bull. I26. 


\section{Arsenate of LeAd ${ }^{21}$}

TIIE PASTE FORM-W -Was first used in fighting insects in New England in IS93.

A compound ${ }^{22}$ of arsenic oxide and lead oxide; remains in suspension better than paris green; is white in color and leaves a mark on foliage; will not ordinarily burn foliage; sticks to plant tenaciously; several applications may injure peach foliage.

The commercial brands vary from $12 \%$ to over $20 \%$ of arsenic oxide 23 -the average being about I $5 \%$. They usually contain less than I $\%$ soluble or free arsenic.

Chemically, arsenate of lead may be (I) of the lead hydrogen, or acid, or plumbic form $\mathrm{PbHAsO}_{4} \mathrm{Or}^{\circ}(2)$ of the basic, neutral, or triplumbic form, $\mathrm{Pb}_{3}\left(\mathrm{AsO}_{4}\right)_{2}$. Ustally the commercial brands are a mixture of these two forms although the acid lead often predominates. The acid lead, when mixed with lime-sulphur for a summer spray, tends to pass through a chenical reaction and form soluble arsenic which is likely to cause burning of the foliage. At the same time the sulphur content of the solution is decreased and its fungicidal value lessened. On the other hand the basic, or neutral lead when combined with lime-sulphur does not have a tendency to form soluble arsenic and it is therefore safer on foliage although not quite so rapid in its effect as a poison. The addition of lime will largely prevent the acid lead from reacting. ${ }^{2 *}$

INJURY TO FOLIAGE BY ARSENATE OF LEAD-The water in which the arsenate of lead is suspended scems to have some determining effect mpon the in-

21 Burgess and Rogers-U. S. Bu. Ent., Bull. 87, p. 17. .

22 Smith-New Jersey Expt. Stat., Bull. 213, p. II.

23 Haywood and McDonnell-U. S. Bu. Chem., Bull. I3 г.

24 Robinson-Jr. Ec. Ent., Vol. I2, p. 429. 
jury caused. ${ }^{25}$ Distilled water with salt added causes decided injury to foliage; distilled water with sodium carbonate added causes decided injury; distilled water alone almost no injury; distilled water with lime added almost no injury. Clear sumny weather following application secms favorable to injury; dew followed by sunshine seems favorable to injury.

Soap is sometimes used as a sticker for arsenate of lead and as an agent to hold it in suspension. ${ }^{26}$

Drying and freezing of the paste and effect on its powers of suspension and adherence to foliage.

THE POWDERED FORM ${ }^{27}$ - It is a fine, white, amorphous powder, the commercial brands of which seem to be largely composed of the biplumbic form. It was first used in fighting the Mexican cotton-boll weevil. The commercial brands are high in arsenic oxid containing generally about $30 \%$. Experiments have shown that it is equal in effectiveness to the paste form when combined with a suitable carrier. Experiments have also shown that when tested on glass slips some brands do not adhere quite as well as the paste form. It can be used in combination with liquid lime-sulphur or with Bordeaux mixture or alone in water or it can be used as a dust alone or combined with dry sulphur.

\section{Arsenate of calcium}

Arsenate of calcium ${ }^{28}$ is cheaper than the lead form of arsenates and is apparently effective in poisoning power, although perhaps not quite equal to the hydrogen lead arsenate. In general the two forms (I) calcium hydrogen arsenate CaIIAsOt

25 Haywood and McDonnell-U. S. Bu. Chem., Bull. I3I.

${ }_{26}$ Cooley-Montana Expt. Stat., Bull. 86.

27 Hinds-Jr. Ec. Ent., Vol. 6, p. 477.

${ }^{28}$ Lovett and Robinson-U. S. Dept. Agr., Jr. Agr. Res., Vo1, X, p. I99. 
and (2) tricalcium arsenate $\mathrm{Ca}_{3}\left(\mathrm{AsO}_{4}\right)_{2}$ are the forms that have been used. The latter appears to be more stable and less liable to form soluble arsenic and is therefore safer to use as a spraying material.

The calcium hydrogen arsenate when combined with lime-sulphur for summer spraying is likely to give severe burning depending somewhat on weather conditions. The commercial mixtures appear to be a combination of the calcitm hydrogen arsenate and the tricalcium arsenate. When composed of pure tricalcium arsenate less injury may be expected. Calcium arsenates are high in arsenic content and when manufactured properly may prove to be of much use in spraying operations. At present they are in the experimental stage.

\section{Arsenite of ZINC}

Arsenite of zinc ${ }^{29}$ is a white powder and high in arsenic content containing about $40 \%$ of arsenious oxide. It has been used with success apparently in the Pajaro Valley, Calif., on the foliage of apple, potato and bean. In the East it has proven dangerous on apple foliage when used alone or with limesulphur. In combination with Bordeaux mixture it appears to cause no injury to apple foliage. It is of use in spraying potatoes because of its high toxic quality.

$$
\text { "SiLuG-SHOT" }
$$

This appears to be mostly composed of gypsum and not of much value as an insecticide. ${ }^{30}$

\section{Bug DEATH}

Ts another trade insecticide of little value for it is largely composed of zinc and iron oxids. ${ }^{31}$

29 Schoene-N. Y. State Expt. Stat., Tech. Bull. 28.

${ }^{30}$ Van Slyke-N. Y. State Expt. Stat., Bull. I65.

31 Smith-New Jersey Expt. Stat., Bull, 2I4, p. I4. 


\section{BLACK DEATH}

It is composed mostly of gypsum. ${ }^{32}$

\section{LONDON PURPLE ${ }^{33}$}

It is a waste product in the manufacture of aniline dyes; contains a large percent of soluble arsenic and must have lime added in liberal amounts to prevent burning. It is not used to any extent.

\section{HELLEBORE ${ }^{3+}$}

The term "hellebore" is said to be correctly applied only to Helleborts niger which grows in Europe and is not now imported commercially.

It is a whitish poisonous powder obtained from pulverizing the roots of the hellebore plants I' $\mathrm{Cra}^{-}$ trum album and Teratrum viride. The powder of the former is largely imported while that of the latter is an American product. Both seem equally valuable as insecticides. It is apt to lose its strength quickly and often difficult to obtain fresh. Can be applied to ripening fruit without fear of poisoning, hecause its strength is so rapidly lost in open air. It is valuable for the currant worm and is usually applied dry either pure or mixed with flour or lime at the rate of $\mathrm{I}$ to 3 ; may be applied wet by steeping I ounce in a quart of water and adding another quart of cold water.

\section{POISON BAITS}

A mixture of fruit juice, bran, and paris green or white arsenic for cutworms, grasshoppers, and army worms has proven very efficient. A recom-

32 Van Slyke-N. Y. Statc Expt. Stat., Bull. 165.

33 Narlatt-U. S. Dept. Agr., Far's' Bull. 127, p. 8.

${ }^{34}$ Cook, Hutchison and Scales-U. S. Bu, Ent., Bull. 245, p. 17. 
mended formula ${ }^{35}$ for cutworms is as follows: 2 pounds of paris green, 50 pounds of wheat bran and six finely chopped oranges or lemons. Bring this mixture to a stiff dough by adding cheap molasses and distribute over the field in small lumps and near each plant.

The formula ${ }^{36}$ used so successfully in Kansas for poisoning grasshoppers is as follows: I pound of paris green, 20 pounds of wheat bran, 2 quarts of syrup, the juice and pulp of 3 oranges or lemons, and $3 \frac{1}{2}$ gals. water. The bran and paris green are thoroughly mixed while dry. The juice of the oranges is squeezed into the water after which the pulp and skin are chopped fine and added to the water. The syrup is then poured into the water and this liquid mixture of fruit juice, syrup and water is used to thoroughly dampen the bran and paris green. The bait is sown broadcast in the infested fields in the early morning.

In Canada a mixture of shorts, 50 pounds; molasses, I gallon; paris green, I pound; and water, I $1 / 2$ gallons has been effective. ${ }^{37}$ The shorts do not dry out as rapidly as bran. For cutworms that feed below the surface the bait should be harrowed into the soil.

Freshly cut clover dipped in a strong arsenical solution is effective for cutworms. Renew as often as it dries.

Slices of potatoes dusted with an arsenical distributed about beds in a greenhouse are effective against sowbugs.

\section{CONTAC"T SUBSTANCES FOR SUCKING INSECTS}

I. Pyrethrum.

35 Walton and Davis-U. S. Dept. Agr., Far's' Bull. 739.

${ }^{36}$ Dean-Jr. Ec. Ent., Vol. 7, p. 67.

37 Strickland-Canad. Dept. Agr., Ent. Br., Circ. 6, 1916. 
2. Tobacco.

3. Soaps.

4. Oils.

5. Lime-sulphur.

6. Carbolic-acid emulsion.

\section{Pyrethrum}

Commonly called Persian Insect Powder, ${ }^{35}$ Dalmatian powder, and Buhach; formerly imported under -two first names; now manufactured in California under name Buhach. It is a powder made from the pulverized flower heads of Chrysanthemum cincraricfolium; contains a volatile oil and kills by contact; harmless to human beings and to plants. It is expensive and soon loses its effectiveness when exposed to the air. Buhach is most apt to be fresh. It is used chiefly in greenhouses and in the household where it is usually sifted dry on the plants or in the rooms. It may be applied wet by steeping $\mathrm{I}$ ounce in a quart of boiling water for 5 or Io minutes to which 3 quarts of cold water should be added.

\section{TOBACCO}

The insecticidal power of tobacco is due to the nicotine it contains. Is often used as a dust ${ }^{39}$ against plant and animal lice and against ticks. It is said to be useful in controlling the woolly aphis on the roots of apple trees and also acts as a good fertilizer. It is a waste product of tobacco factories and costs about I cent per pound.

Tobacco stems or leaves may be cooked or steeped in water to remove the nicotine and form a

38 Marlatt-U. S. Dept. Agr., Far's' Bull. I27, p. I6.

Coquillet-U! S. Bu. Ent., Bull. I2, o. S.

39 Smith-N. J. Expt. Stat., Bull. 2I3, p. 28. 
decoction. Unfortunately, the nicotine content of tobacco varies with the variety, soil, method of curing and other factors ${ }^{* 0}$ and it is therefore impossible, without chemical analysis, to make a standard decoction. In general, I pound of stems in a gallon of water brought to the boiling point and when drained off enough water added to make a full gallon will give a decoction of sufficient strength to kill plant lice. It is best to rely on commercial extracts whose nicotine contents are known.

COMMERCIAL TOBACCO EXTRACTS-Extracts of tobacco are now manufactured commercially and are known as nicotine sulphate. Nicotine sulphate appears to kill insects by its vapor. ${ }^{41}$ The most familiar brand is known as black-leaf-40. In this brand the nicotine is combined with an acid and hence is not easily volatile. It contains $40 \%$ nicotine and is readily miscible with water. Tt is usually used at the rate of I gallon to 800 or Iooo gallons of water. It can be combined with lime-sulphur, and arsenate of lead or with Bordeaux mixture. ${ }^{42}$ When the nicotine sulphate is used alone, soap is usually added at the rate of 4 or 5 pounds to IoO gallons of water to increase its spreading power and to liberate the nicotine. ${ }^{43}$ A precipitate is sometimes formed when nicotine sulphate is added to other mixtures especially when in a concentrated form.

\section{SoAps ${ }^{44}$}

Ordinary laundry soap, I pound to 5 or 6 gallons of water is a good insecticide for the garden, lawn,

40 Ellet and Grissom-Vir. Expt. Stat., Bull. 208.

${ }^{41}$ McIndoo-U. S. Dept. Agr., Jr. Agr. Res., Vol. VII, p. Sg.

42 Headlee-New Jersey Expt. Stat., Rept. Ent. for 19I4, p. 356.

${ }_{43}$ Moore and Graham-U. S. Dept. Agr., Jr. Agr. Res., Vol. X, 1). 47 .

${ }_{44}^{4}$ Marlatt-U. S. Dept. Agr., Far's' Bull. I27, p. I5. 
and houschold plants. Soft soap should be used twice as strong.

Whale-oil soap is more commonly used. One should always procure a potash soap. It costs 3 to 6 cents per pound. Use I pound to 5 or 6 gallons of water for summer application. In winter, for scale, use 2 pounds to I gallon. Whale-oil soaps vary greatly in their water content and are liable to contain free potash thus causing burning. Fishoil soap can he made easily and cheaply at home. The composition may be known and the free potash avoided.

Formula for home-made fish-oil soap: ${ }^{45}$

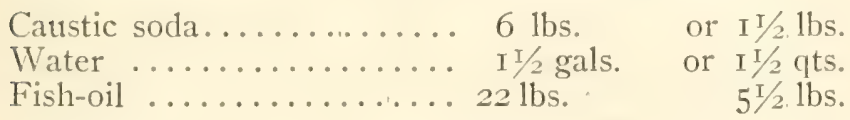

Dissolve the caustic soda in the water. After the soda is dissolved, add the fish-oil gradually, in the meantime stirring the mixture thoroughly and vigorously. Complete and thorough stirring while the oil is being slowly poured into the water and soda is absolutely necessary. L'se I pound to 6 or 7 gallons of water.

Fish-oil may be purchased of N. B. Cook Oil Co., New York.

\section{OILS}

Mineral oils are much used for contact insecticides, usually in some form of an emulsion that is miscible with water. They are particularly valuable against aphids, and scale insects.

Kerosene emulsion ${ }^{46}$-Kerosene may be emulsified with milk or soap, the latter being now most universally used.

Formula for kerosene emulsion:

45 Van Slyke \& Urner-N. Y. State Expt. Stat., Bull. 257. 
Soap ......... I lb. Soap ........ I/2,lb.

Soft water..... 2 gals. or Water ........ I gal.

Oil .......... 4 gals. Oil .......... 2 gals.

The soap is shaved fine and heated in the water until dissolved. The oil is poured in and while the mixture is hot it is briskly agitated until a white creamy mixture is formed. The following dilutions apply to first formula:

To make a ro\% solution for summer spraying add 34 gals. water.

To make a $20 \%$ solution for dormant spraying add I4 gals. water.

To make a $25 \%$ solution for dormant spraying add Io gals. water.

Crude Petroleum emulsion-It is made exactly as the kerosene emulsion. The grade of oil used is called "insecticide oil." It should have an amber color and its specific gravity should run from 43 to 45 degrees Baumé. A 20 to 25 percent solution is valuable as a winter spray.

OIL IN MECIIANICAL EMULSION WITH WATER ${ }^{47}$ It has always been tedious to make oil emulsions and to obviate the labor, pumps were designed to mix the oil mechanically with water. These pumps were supposed to throw any per cent of oil in water desired, by the regulation of a valve. The pumps proved unreliable and severe injuries often resulted from using them. They are not now in use.

Miscible orls ${ }^{48}$ - These are proprietary mixtures containing mineral oils in combination with a small quantity of vegetable oil and some alkali to make them miscible with water. They are designed especially for the control of scale insects. They mix readily with water. There are several prom-

46, ${ }^{47}$ Marlatt-U. S. Dept. Agr., Far's' Bull. I27, p. 20.

48 Marlatt-U. S. Dept. Agr., Far's' Bull. I27, p. 23. 
inent brands: "Scalecide," "Kil-O-Scale," "Target-Brand," and "Orchard Brand."

Home-made miscible oils ${ }^{49}$-Prof. C. L. Penny has developed methods of preparing miscible oil at home. There are two steps in making a miscible oil: ( I) preparing the emulsifier or soap solution, (2) mixing the mineral and vegetable oils with the emulsifier to produce the final product, miscible oil. The process is rather long and laborious.

\section{Carbolic acid emulsion}

This emulsion is formed by dissolving I pound of hard soap in I gallon of hot water. After the soap is dissolved, add I pint of crude carbolic acid. Then agitate the mixture until an emulsion is formed. For use, dilute with 30 parts of water.

\section{LIME-SULPHUR ${ }^{50}$}

It is probably the best and most universally used insecticide for scale insects. It is also practically a specific for blister-mite and of great use in controlling the pear psylla, certain fungous diseases, etc. It was used originally as a sheep dip but was first tried as an insecticide in California in 1886. It was not tried in the East until I89+ when its use did not seem to prove successful. Nothing more was done with the lime-sulphur wash in the East until I900 when it was tried again and gave promising results. The first formulae included salt. Later formulae differed somewhat in proportions, but the following is a representative one: Quicklime, 20 pounds; sulphur, I 5 pounds; water, 50 gallons.

49 Penny-Ann. Rpt. Penn. State Coll., I907-08, p. 228.

Phillips-Va. Expt. Stat., Bull. I79.

50 Quaintance-U. S. Dept. Agr., Yearbook I906, p. 429. 
Place lime in iron kettle and slake it with hot water. Add sulphur and more water and boil for one hour. Dilute to 50 gallons, strain, and use while hot if possible.

Concentrated Commercial SOlutions ${ }^{51}$ Within the past few years commercial concentrated lime-sulphur solutions have been introduced into this state and have been used by many fruit growers in combating certain insect pests and fungous diseases. In order to use one of these mixtures intelligently and effectively it becomes necessary to know its strength or, in other words, its degree of concentration. This is best found by using an instrument known as a Baumé hydrometer. In testing a lime-sulphur solution, simply pour some of the clear reddish licuicl into any deep receptacle, deeper than the hydrometer is long, and when nearly full, gently drop the instrument into the solution and wait until it comes to rest. Then read on the hydrometer the degree of concentration, which will

\begin{tabular}{|c|c|c|c|c|}
\hline \multirow{3}{*}{$\begin{array}{c}\begin{array}{c}\text { Reading of } \\
\text { hydrometer or } \\
\text { degree of } \\
\text { concentration }\end{array} \\
\text { Degrees Baumé }\end{array}$} & \multicolumn{4}{|c|}{$\begin{array}{l}\text { Amount of water to one gallon of the } \\
\text { lime-sulphur solution }\end{array}$} \\
\hline & \multicolumn{2}{|c|}{ For San José Scale } & \multicolumn{2}{|c|}{ For Blister-mite } \\
\hline & Gals. & $\begin{array}{l}\text { Gals. } \\
\text { Water }\end{array}$ & $\begin{array}{c}\text { Gals. } \\
\text { Lime-Sulphur }\end{array}$ & $\begin{array}{l}\text { Gals. } \\
\text { Water }\end{array}$ \\
\hline $\begin{array}{l}25 \\
26 \\
27 \\
28 \\
29 \\
30 \\
31 \\
32 \\
33 \\
34 \\
35\end{array}$ & $\begin{array}{ll}\text { I } \\
\text { I } \\
\text { I } \\
\text { I } \\
\text { I } \\
\text { I } \\
\text { I } \\
\text { I } \\
\text { I } \\
\text { I } \\
\text { I }\end{array}$ & $\begin{array}{l}5 \\
5^{1 / 4} \\
5^{33 / 4} \\
6 \\
6^{1 / 2} \\
63 / 4 \\
7^{1} 1 / 4 \\
7^{1 / 2} \\
8^{1 / 2} \\
8^{1 / 4} \\
83 / 4\end{array}$ & $\begin{array}{l}\text { I } \\
\text { I } \\
\text { I } \\
\text { I } \\
\text { I } \\
\text { I } \\
\text { I } \\
\text { I } \\
\text { I } \\
\text { I } \\
\text { I }\end{array}$ & $\begin{array}{l}7 \\
71 / 2 \\
8 \\
81 / 2 \\
9 \\
9^{1} / 2 \\
10 \\
10^{1} / 2 \\
\text { II } \\
\text { II } 1 / 2 \\
12\end{array}$ \\
\hline
\end{tabular}

51 Parrott \& Schoene-N. Y. State Expt. Stat., Bull. 320. 
be the one just at the surface of the licuicd. When the degree of concentration of the liquid is linown, the proper dilution may be obtained by referring to the table ${ }^{52}$ on page 24 .

HoMe-MAde CONCENTRATED SOLUTION ${ }^{53}$-The concentrated solution can be made at home with a fair degree of success. The lime used should contain not less than go/ calcium oxid and not orer $5 \%$ magnesium. The formula is as follows:

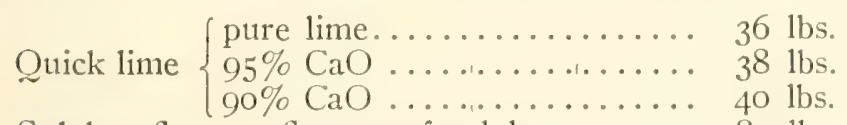

Sulphur flour or flowers of sulphur....... 80 lbs.

Water ........................... 50 gals.

Place lime in kettle and slake with Io gallons of water. While lime is slaking add the sulphu1 which has been previously mixed with water into a paste. Stir thoroughly and when lime is entirely slaked add enough water to make about 60 gallons if the boiling is over an open fire. If the boiling is with live steam add enough water to make 50 gallons. Boil the mixture vigorously for one hour.

When through, strain; store in tight containers. Usually lime-sulphur will not freeze down to 5 above ezro.

For San José scale the diluted solution should test 4.5 degrees B.; for the blister-mite about 3.5 B.; and for summer use on foliage about I degree $\vec{P}$.

The concentrated solutions of lime-sulphur have shown themselves to be useful against San José scale in the summer eren when diluted for use on foliage. ${ }^{54}$

The self Boiled Lime-Sulpitur-This has been 52 Van Slyke, Bosworth, and Hedges-N. Y. State Expt. Stat., Bu11. 329.

${ }_{53}$ Parrott and Schoene-N. Y. State Expt. Stat, Bull. 330.

54 Stewart-Ann. Rpt. Penn. State Coll. I9I0-I I, p. 268. 
found to be of use in checking San José scale ${ }^{55}$ in the summer. Place 8 pounds of quick lime in a barrel and start it slaking with a small amount of cold water. Work s pounds of sulphur through a sieve and add slowly to the slaking lime. Add enough cold water to slake the lime and stir constantly. As soon as slaking is completed ( 5 to I 5 min.) fill barrel with cold water (50 gallons). Peaches and plums can be sprayed in foliage with this and the scale checked if hit when young are hatching.

DRY SUBSTITUTES FOR LIQUID LIME-SULPHURSeveral commercial dry preparations are on the market as substitutes for the liquid lime-sulphur. Such preparations as "spra sulphur," soluble sulphur," "lry lime-sulphur" and "I'. T. S." are among those offered. Some of these are sodium-sulphur compounds, some barium-sulphur compounds, and some lime-sulphur compounds. They vary widely in the amount of sulphur contained and are valuable, other things being equal, according to the amount of sulphur each actually contains. The standard liquid lime-sulphur solution ( $33^{\circ}$ Baumé) at a dilution of $\mathrm{I}$ to 8 for scale contains 4.75 ounces of sulphur or $3.45 \%$ efficient sulphur per gallon. The summer dilution for scab at $\mathrm{I}$ to 40 contains I.Of ounces of sulphur or $.775 \%$ efficient sulphur per gallon. When the dry compounds are used they should also contain an equivalent amount of efficient sulphur in order to control the scale or scab effectively. Manufacturers are apt to recommend their dry materials at too low dilutions to make them efficient.

Moreover, arsenicals cannot be combined with safety with those dry compounds containing sodium or potassium sulphides.

${ }^{55}$ Quaintance-U. S. Dept. Agr., Yearbook 1908, p. 277. 


\section{FUMIGATING SUBSTANCES}

Several substances are used to fumigate mills, greenhouses and dwellings in order to destroy the insects that may be infesting such buildings.

Carbon Bisulpitide ${ }^{56}$ - This liquid is used as a fumigant against stored grain insects especially and sometimes against root-feeding insects, aphids, white grubs, ants, etc.

It is heavier than water; readily volatile; and when pure it has not an umpleasant odor. The gas from the lifuid is heavier than air and is suffocating. The gas is also inflammable and explosive.

Use 2 pounds of the liquid ${ }^{57}$ to Iooo cubic feet of space when temperature is between 65 and 75 degrees F. Granary must be tight. Peas, beans, seed corn, etc., can be stored in barrels and treated. Under ordinary granary conditions, I5 to 20 pounds to IOOO cu. ft. should be used.

A cheap form of carbon bisulphide under the trade name "Fuma," is sold by Edward R. Taylor, Penn Yan, N. Y.

HyDROCYANIC ACID GAS-It is a very poisonous gas used against household insects, citrus pests, stored grain insects, and for the fumigation of nursery stock.

Formula for household fumigation for IOO cubic feet space:

Water ..................... 3 fluid ozs.

Sulphuric acid .............. I fluid oz.

$98 \%$ potassium cyanide............. I oz.

Sodium cyanide has almost supplanted potassium cyanide for fumigation purposes and should be used according to the following formula for each IOO cubic feet of space:

56 Hinds-U. S. Dept. Agr., Far's' Bull. I45.

57 Chittenden and others-U. S. Bu. Ent., Bull. 96, Part III, 
Water ...................... 2 fluid ozs.

Sulphuric acid ............. I I 2 fluid ozs.

Sodium cyanide .............. I oz.

For house fumigation is all holes in rooms should be stopped and all cracks covered with strips of newspaper soaked in water.

In fumigating trees tents are used. ${ }^{59}$ In fumigating nursery stock for scale insects a special room is needed. ${ }^{60}$

Formaldemyde Gas-This is primarily a germicide. It has been shown to be practically useless as an insecticide.

TOBACCO PAPERS-Paper soaked in tobacco extract is sold for fumigation purposes in greenhouses. These papers will burn when lighted and are much more convenient to use in houses than tobacco stems.

\section{HEAT $^{61}$}

Within the last few years heat has been used to some extent in mills in the western part of the United States, at least, to kill mill insects. According to Dean and Goodwin heat is a very efficient and satisfactory agent for destroying grain insects. The temperature necessary to kill stored grain insects ranges from I $8^{\circ}$ to $\mathrm{I} 25^{\circ} \mathrm{F}$. Felt has shown that cockroaches succumb to a temperature of $\mathrm{I} 2 \mathrm{O}^{\circ} \mathrm{F}$. It is necessary to maintain the heat for several hours to allow it to penetrate all

58 Howard and Popenoe-U. S. Bu. Ent., Circ. I63.

Herrick-Can. Ent., Vol. 39, p. 34I.

59 Morrill-U. S. Bu. Ent., Buli. 76.

Woglum-U. S. Bu. Ent., Bull, 79.

Woglum--U. S. Bu. Ent., Bull. 9o, Parts I and II.

60 Britton-Conn. Expt. Stat., Bull. of Immediate Information No. 3.

61 Goodwin-Ohio Expt. Stat., Bull. 234.

Dean-Kan. Expt. Stat., Bull. I89.

Felt-27th Rept. State Ent., N. Y. 
of the infested parts of the building. There is no reason why heat conld not be utilized to kill household insects if a practicable way can be found of developing a temperature of $\mathrm{I} 25^{\circ} \mathrm{F}$. in a house.

\section{MISCELLANEOUS MEANS OF FIGHTING IN- SECTS}

Trap LANTERns-Lights and lanterns have been recommended and used for many years to catch insects active at night. One called the Hazeltine lantern has been widely advertised. Several experiments have been made to demonstrate the usefulness or uselessness of lanterns for catching insects. Perhaps the most extensive one was made at Cornell during i892. From May 20 th to Oct. Ist 13,000 insects were caught; $77 \%$ were neutral, IO $2-5 \%$ beneficial, I $23-5 \%$ often pests; of the pests, $8+$ to $93 \%$ were males; of the beneficial, So to $88 \%$ were females; nymphs and larve were not caught; as many friends as foes were caught; not one codling moth taken. ${ }^{62}$

In an all-summer experiment Dr. Riley never caught a codling moth: Prof. Stedman caught only 2 with 4 lanterns running IoO nights.

Gasoline torches-An ordinary plumber's ${ }^{63}$ torch or some modification of it has been proposed for killing insects, especially scale insects, on their food plants. Several trials by different experimenters on different insects indicate that these torches are hardly practicable. In most cases, the heat sufficient to kill the insects injured the plants.

TREE TANGLEFOOT-A sticky material manufactured by the O. IV. Thum Co., Grand Rapids, Mich., at about $30 \mathrm{oc}$ per pound is the same or similar mate-

62 Slingerland-Cornell Univ. Expt. Stat., Bt11. 202.

${ }^{63}$ Forbes-Illinois Expt. Stat., Bull. 89. 
rial used in their tanglefoot fly paper. It is useful in putting about the trunks of trees to catch cankerworm moths, caterpillars of the tussock moth, etc.

Treeleim-A substance manufactured by the Vrecland Chemical Co., which is used for the same purpose as tanglefoot and is said not to "glass" over but to remain fresh and sticky a long time.

\section{SPRAYING}

History OF SPRAYING-The current worm became injurious about I860 and the Col. Pot. beetle about 1865 . Hellebore and paris green were used for these two pests, and this suggested the use of the latter for other insects. Riley suggested its use on cotton in 1872; Le Baron suggested its use for the canker-worm in $I_{8}>2$. Cook advised spraying trees in 1876 ; E. P. Haynes, in 1878 , sprayed trees for canker-worms and killed the codling moth. These were the beginnings. Our insect foes are increasing and we must spray.

Some Principles of SPRAYING-Spray at the right time, before rains for most fungous diseases and after rains for insects alone. Watch the development of buds, blossoms, fruit and weather and spray accordingly and not by dates. Spray thoroughly. Every leaf and fruit should be coated. Use a nozzle, in general, that gives a fine spray and use at least 75 pounds pressure, but better I5O pounds.

\section{DUSTING}

Dust for control of insects and fungi may consist of lime, dry Bordeaux and some arsenical or it may consist of a mixture of sulphur and an arsenical. These dusts were introduced to lower the cost and labor of spraying. They do both but the ultimate value of them rests on their efficiency. 
Early experiments in dusting trees were made with dry Bordeatxx and an arsenical. In this mixture the copper was the essential fungicide. The following is a formula ${ }^{6+}$ (Scott's), for this dust:

4 lbs. copper sulphate in 4 gals, water

$4 \mathrm{lbs}$. lime in 4 gals, water

60 lbs. slaked lime dust

Dissolve the sulphate in the + gallons water and slake the lime in the 4 gallons. When cool pour together and allow it to settle. Decant or pour off the liquid, put the wet mass in a strong bag and squeeze out the remaining water. Then spread out and allow to dry in the sun. Pulverize this dry material and pass it through a sieve with 80 meshes to the inch and then mix with the 60 pounds of slaked lime. For Bird's formula see Mo. Bull. 6o or Cornell Bull. 2 I 6.

Comparative early experiments indicated that six applications of the dry material could be made as cheaply as four with lifuid. The dust is more easily transported about an orchard, especially if the orchard is rough. It does not appear to have any other advantage, according to early experiments.

The dust did not control fungous diseases as well as liquid Bordeaux. The dust proved irritating to workmen, getting into their lungs.

Crandall ${ }^{65}$ says the "dust spray is absolutely ineffective as a preventive of injury from prevailing orchard fungi, and that it is considerably less efficient as an insect remedy than is the liquid method of applying arsenites."

It nust be remembered that these experiments were made with a Bordeaux dust.

\footnotetext{
64 Scott-U. S. Dept. Agr., Far's' Bull. 243, p. I I.

Craig-Cornell Univ. Expt. Stat., Bulls, 216, 245.

Close-Delaware Expt. Stat., Bulls. 72 and 76.

${ }_{05}$ Crandall-Illinois Expt. Stat., Bull. I06.
} 
The first dusting experiments in which dry sulphur was used to replace lifuid lime-sulphur were made by Blodgett in I9II. ${ }^{66}$ These experiments were continued during IOI 2 and I9I3. The results were encouraging and the work was continued during IOI4 by Reddick and Crosby. ${ }^{67}$ The materials recommended were finely ground sulphur 00 pounds, and powdered arsenate of lead Io pounds, applying from $I^{1} / 2$ to 3 pounds of the mixture per tree at each dusting. Later recommendations advise 85 parts of sulphur to 55 parts of powdered arsenate of lead. ${ }^{68}$ The results for the control of chewing insects and apple scab were enconraging and further experiments are now in progress.

\section{PUMPS}

Atomizers, hand sprinklers, buckets, knapsacks, barrel, power sprayers. The essentials of a good pump are brass or bronze working parts, ball valves, and readily accessible parts.

\section{NOZZLES}

I. The first nozzles threw a nearly round solid stream, like a garden hose.

2. The second group of nozzles consisted of those in which the stream having passed the orifice proper is modified by some obstruction that breaks it or scatters it. The "climax," "Ball," and "Lewis" are examples.

3. The third and most perfect type is known as the rotary or eddy-chamber nozzle. This is represented, typically, by the Vermorel. Tater modifications are the "Friend" and "Mistry." The Vermorel is of American origin although bearing a French

66 Blodgett-Cornell Univ. Expt. Stat., Bull. 340.

${ }^{67}$ Reddick and Crosby-Cornell Univ. Expt. Stat,, Bull. 354.

68 Reddick and Crosby-Cornell Univ. Extension, Bull. I. 
name. Within recent years so-called spraty guturs have come into use.

\section{ACCESSORIES}

Tower-A tower ten or twelve feet high is a necessity for good work. It enables one to get above the tree and spray down, which is especially necessary in case of codling moth. The new Cornell tower has many advantages.

Hose-There should be plenty of hose to enable one to get all around a tree. The hose should be of a quality to withstand I50 to 200 pounds pressure.

\section{BORDEAUX MIXTURE 69}

This is a fungicide with which arsenicals are often combined:

Bordeaux mixture is made by mixing a dilute solution of copper sulfate (blue vitriol) with a dilute milk of lime. The mixture may be made of different strengths by using different amounts of the copper sulfate and lime to a given amount of water. A mixture made of 3 pounds of copper sulfate and 3 pounds of lime to 50 gallons of water is indicated by the formula $3-3-50$; one made of 4 pounds of copper sulfate and 4 pounds of lime to 50 gallons of water, by 4-4-50; one made of 5 pounds of copper sulfate and 5 pounds of lime to 50 gallons of water, by $5-5-50$.

\section{QUARANTINE ANI INSEC'TICIDE LAWS}

Nearly all of the States in the United States have passed laws ${ }^{70}$ governing the shipments of plants and plant products into their territories. These are designed, of course, to prevent the introduction of injurious insects and plant diseases. California has in some instances instituted legal restrictions gioverning shipments of plants between connties

${ }^{69}$ Cornell Univ. Expt. Stat., Bull. 283, Rev. Ed., p. 466, I9I5.

70 Burgess-U! S. Bu. Ent., Circ. 75. 
within the State. Similar restrictions have also been imposed in some of the Southern States to prevent the spread of the Mexican cotton-boll weevil from one district to another within the State. These laws of the different States are intended to meet local conditions and are not uniform which results in much confusion.

The National Quarantine Law-For many years there was in this country an agitation for a uniform, national quarantine law to govern the importation of nursery stock into the United States and to regulate the shipment of such stock among the States themselves. As a result of this demand, Congress passed such a law, ${ }^{71}$ which went into effect the first day of October, IgI2. The law has two purposes: (I) to regulate the importation of nursery stock, other plants, and plant products from foreign countries into the United States to prevent the introduction of injurious insects and plant diseases; (2) to establish quarantines against any State, territory, or district of the United States or any portion thereof to prevent the distribution throughout the Lnited States of any dangerous plant diseases or injurious insects.

To carry out the provisions of the law, a Federal Horticultural Board consisting of five members was appointed by the Secretary of Agriculture from certain Bureaus and offices in the Department of Agriculture.

The National Insecticide Law - Various States have undertaken at different times to regulate by law the composition of certain insecticides sold within their boundaries. Such laws have not been uniform and have been, on the whole, more or less unsatisfactory. In I9ro Congress passed a

71 An Act to regulate the importation of nursery stock, etc. Public Document-No. 275 . 
national insecticide law that went into effect the first day of January, I9II. Its object was to prevent the manufacture, sale, or transportation of adulterated or mishranded paris greens, lead arsenates, and other insecticides and fungicides. In this law it was decreed that paris green shall not contain less than 50 per cent arsenious oxide nor more than $3 \frac{\mathrm{T} / 2}{2}$ per cent water-soluble arsenic and that lead arsenate shall not contain more than 50 per cent water, nor less than $121 / 2$ per cent arsenic oxide $\left(\mathrm{As}_{2} \mathrm{O}_{5}\right)$ nor more than .75 per cent. watersoluble arsenic. It was also decreed that other insecticides and fungicicles should not fall below the proposed standard or quality under which they were sold. 


\section{INSECTS INJURIOUS TO ORCIIARD TREES AND FRUITS}

\section{APPLE PESTS}

\section{The CODLING moth ${ }^{1}$ (Carpocapsa pomonella) \\ Order-Lepidoptera. Manual p. 24 I}

One of the oldest and most important pests on apples; estimated that it causes a yearly loss of $\$ 12,000,000$ in the United States with an added $\$+, 000,000$ for cost of spraying trees to control it.

Eggs laid on leaves and fruit about two weeks after petals fall; caterpillars emerge in about one week and 60 to $80 \%$ enter the young fruit through the calyx end; they live in the apple from 25 to 30 days, or longer in many instances, and when fullsrown leave the fruit through a hole made in the side of the apple; they then crawl to a crevice in the bark of the large limbs or trunks or find a nook elsewhere and spin a cocoon; here, some of the larva change to pupre and issue as moths the latter part of July to form a partial second brood in New York State; a large part of the larve, however, remain under the bark until the following spring and then change to pupre from which, in about twenty days, the adult moths issue. All of the larva of the second generation remain in cocoons under the bark until spring.

Control-Spray at once after three-fourths of the petals have fallen, with I 50 pounds pressure, using $2 \frac{\mathrm{T}}{2}$ pounds of paste arsenate of lead to 50

1 Slingerland-Cornell Univ. Expt. Stat., Bull. I42.

Quaintance-U. S. Dept. Agr., Yearbook I907, P. 435. 
gallons of water; this is the most important spraying and should be done thoroughly; spray from a tower into the calyx ends of the young apples: spray again in $3 \mathrm{Or}^{\circ}+$ weeks and cover fruit and foliage with a fine misty spray; again the last week in July for second brood.

THE ROUND-HEADED BORER ${ }^{2}$ (Saperda candida)

Order-Coleoptera. Manual p. 573

Next after the codling moth the worst pest on apples in the United States; eggs laid in June and later, in incisions made in the bark; the eggs hatch in 2 or $^{\circ}$ weeks and tunnel in the sapwood; they live mostly near the surface of the ground, but often below the earth, especially in young trees; at end of the second year the larvie are quite large and are now deeper in the heartwood; the third spring the larve gnaw to the lark and there pupate; the adult beetles emerge in May and June, the insect having taken three years for its life history; in TVest Virginia and in Arkansas the life cycle may be passed in two years; the beetle is a handsome long-horned one, about an inch in length and has two conspicuous white lines the whole length of its body.

Control-Give orchards clean culture; cut out borers with a sharp instrument like a chisel and then apply some wash, for instance, concentrated lime-sulphur, or an alkaline wash made by adding caustic potash to soap and water until a thick creany mixture is formed; washes should be applied up to the lower limbs.

FLAT-HEADED BORER ${ }^{3}$ (Chrysobothris femorata)

$$
\text { Order-Coleoptera. Manual p. } 549
$$

The second thoracic segment of the larra is wide,

2 Becker-Ark. Expt. Stat., Bull. I46.

${ }^{3}$ Chittenden-U. S. Bu. Ent., Circ. 32. 
flat, and close to the head, hence the name; the larva attacks many kinds of fruit-trees, forest and shadetrees, infesting by preference those diseased or dying; it inhabits all parts of the trunk from ground to branches; eggs are laid in cracks of bark; the larva lives just beneath the bark and burrows out broad, flat, irregular channels in the wood; as it grows it may go deeper into the wood; it matures in one year and the beetles emerge in May and June; the adult beetle has short antennxe, is of a dark metallic brown color, and about one-half inch long.

Control-Same as for the round-headed borer.

\section{THE BUD-MoTH ${ }^{4}$ (Tmetocera ocellana)}

Order-Lepidoptera. Manual, p. 24I

A most important pest on the apple in New York. The tiny dark brown caterpillars appear early in the spring and begin to attack the bursting buds; they bore into the buds and when the leaves begin to unfold attack those also; they continue to eat the leares and tie them together, finally pupating within the tangled mass; the moths appear in June and lay their small inconspicunus eggs on the leaves; these hatch in about io days and the tiny caterpillars feed on the surfaces of the leaves eating the epidermis and tissues away, leaving a network of veins; the caterpillar lives mostly in a tiny silken tube built along the midrib of the leaf; in September the caterpillars migrate from the leaves to the small branches where they build snug silken cases, called hibernacula, in which to pass the winter; these hibernacula are built very often near the buds where the larve will find food close at hand in the spring. There is only one brood a year.

Control-Add arsenate of lead, $2 \mathrm{I} / 2$ pounds to 50 gallons, to the delayed dormant spray just as the

${ }^{4}$ Slingerland-Cornell Univ. Expt. Stat., Bull. 50. 
tips of the bucls begin to show green; repeat just before blossoms open; repeat again after petals fall which will also do for the first codling moth spray. Combination sprays containing nicotine sulphate and lime-sulphur may be used.

\section{Cigar CASE-BEARER ${ }^{5}$ (Coleophora fletcherella) Order-Lepidoptera}

The half-grown caterpillars migrate in August and September from the leaves to the branches, where they securely fasten their small curved cases preparatory to passing the winter; in the early spring the caterpillars in their cases become active, move to the buds and begin to attack them; later they attack the very young fruit but mostly mine in the leaves remaining all of the time in their cases; about the middle of June they pupate and the moths appear in July; the very small moths lay their eggs on the leaves; these hatch in about 2 weeks and the tiny caterpillars spend the remainder of the summer mining in the leaves.

Control-Spray with arsenate of lead, $2 \mathrm{I} / 2$ pounds to 50 gallons of water just as the tips of the buds begin to show green; again before the blossoms open; and again after petals fall. This is the same as for the bud-moth.

\section{Pistol Case-Bearer ${ }^{6}$ (Colcophora malirorclla) Order-Lepidoptera}

Its case is shaped like a pistol and its life history is very similar to that of the cigar case-bearer; the larva, however, does not mine in the leaves but eats the surfaces of them.

Control-Same as for cigar case-bearer.

5 Slingerland-Cornell Univ, Expt. Stat., Bull. 93.

6 Slingerland-Cornell Univ. Expt. Stat., Bull. I24. 


\section{TIIE APPLE-GRAIN APHID ${ }^{7}$ (Rhopalosiphum prinifoliac) \\ Order-Hemiptera}

This aphid is a European insect and has been observed on more than twenty-two plants-apple, pear, quince, plum, rye, oats, wheat, et al.; it is one of the early aphids appearing in the spring on apple buds but usually leares the apple without doing much harm; it is light green in color with a dark line down the middle of its back.

Passes winter as dark eggs on branches; these hatch in spring; may be several generations on apple leaves; the winged generation flies to grasses where many generations are produced during the summer; many live on wheat in fall; the winged females finally fly back to the apple tree in the fall and produce a generation of wingless ego-laying females which lay the winter egos on the bark.

Control-See green apple aphid.

THE ROSY APPLE APHJD ${ }^{8}$ (Aphis sorbi-A. malifoliae)

Order-Hemiptera

The rosy aphid is larger than the grain aphid and is usually of a rosy color although individuals may be tan, grey or blackish, while the body is covered with a whitish powder; the body is noticealbly globular; this aphid is often very injurious.

It winters as eggs upon the trunk and branches of the apple tree; the egs hatch in spring and probably three and perhaps more (depending on latitude) generations are produced on the apple tree; in late June winged individuals begin to leave the

${ }^{2}$ Baker and Turner-U. S. Dept. Agr., Jr. Agr. Res., Vol. I8, p. $3 \mathrm{II}$.

Davis-U. S. Bu. Ent., Bull. I I2.

8 Quaintance-U. S. Bu. Ent., Circ. SI.

Matheson-Cornell Univ. Expt. Stat, Memoir 34. 
apple tree and go to the broad-leaved and narrowleaved plantains where the summer is spent; in the fall the return migrants come back to the apple where egg-laying females are produced and the eggs are laid, thus completing the cycle.

CONTROL-See the green apple aphid.

The green apple aphin" (Aphis pomi-Aphis mali)

Order-Hemiptera

The green apple aphid resembles the grain aphid but is darker green and lacks the dark line down the back; it has not been recognized as seriously injurious in this country until of comparatively recent years; it is now considered the most injurious species; it winters as eggs on the trees and spends the whole year on the apple, not having alternate food-plants like the two preceding species; the aphids curl the leaves, stunt the new growth and often stunt and deform the apples.

CONTROL-The eges of these aphids, although there is some individual variation, those of the grain aphid hatching earliest, hatch early in the spring, about the time the flower buds begin to swell and break and the leaves show green at the tips. The young aphids cluster on the outside of the buds where they are all exposed to contact with spray material. Then is the time to kill them. Later they get in between the leaves of the buds and in rolled leaves and cannot be hit easily or not at all.

The safest and most efficient material with which to kill the aphids at this time is nicotine sulphate alone, $3 / 4$ of a pint to IOo gallons of water with 5 pounds of soap added, or combined with lime-sul-

9 Parrott, Hodgkiss, and Lathrop-N. Y. State Expt. Stat., Bulls. 415 and 43 I.

Hodgkiss-N. Y. State Expt. Stat., Bull. 46I. 
phur solution at the same rate but without the soap. Arsenate of lead may be added if desired.

In case of the green apple aphid especially it may he necessary to make later applications of the nicotine sulphate owing to repeated infestations in June and July. It has proven adrantageous at this time to add rather large quantities of quick lime or hydrated lime ${ }^{10}$ to the nicotine sulphate and water, leaving out the soap. The mixture of nicotine sulphate and lime seems to have a deterrent effect on the aphids in addition to its killing properties.

\section{THE FALL CANKER-WORM (Alsophila pometaria)}

Order-Lepidoptera. Manual, p. 276

Moths emerge in late fall and the wingless females lay their eggs in clusters on bark; eggs rest over winter and hatch in early Nay; larva which are loopers and have only 3 pairs of abdominal legs feed for a month and in June and July go into the ground to change to pupxe in dense cocoons, and remain here until fall when the moths appear again; one brood a year.

THE SPRING CANKER-WORM ${ }^{11}$ (Paleacrita vernata)

Order-Lepidoptera. Manual, p. 275

Moths emerge in March and April and lay their egcrs in small clusters in crevices of the bark; caterpillars which are loopers and have only 2 pairs of abdominal legs hatch in May and in June and July go into the ground where they remain as pupa until the next spring; one brood a year; the female is gray and wingless and bears two transverse rows of short spines on the dorsal side of each of the first seven segments of her abdomen; the spring

10 Hodgkiss-N. Y. State Expt. Stat., Bull. 46I.

11 Quaintance-U. S. Bu. Ent., Bull. 68, Pt. II. 
canker-worm is usually the common one in New York.

Contror-Caterpillars quite resistant to poisons, yet arsenate of lead, 6 to io pounds to Ioo gallons of water will control them; also bands of sticky material, like tar, tangle foot or printer's' ink to prevent the females from climbing trees to lay eggs; bands of fluffy cotton batting; will serve; apply in October for fall canker-worm and in early spring for spring canker-worm; also plow and cultivate in August or September to destroy the pupe in the soil.

The APPLE TENT-CATERPILlaR ${ }^{12}$ (Malacosoma

\section{americana)}

Order-Lepidoptera. Manual, p. 360

Passes winter as eggs laid in rings around branches; eggs hatch as buds begin to burst and larva build tents in crotches of branches; in + to 6 weeks the caterpillars become grown and make dense cocoons in secluded places; in about 2 weeks the moths appear and deposit eggs during last of June or first of July.

Control-Collect and burn egg masses; school children are often enlisted in the work of collecting and destroying the ege masses; spray infested trees with arsenate of lead $2 \mathrm{I} / 2$ pounds to 50 gallons of water just as the buds begin to open; repeat in a week if necessary; destroy wild cherry and seedling apple trees along the fence rows. Burn out with gasoline torch. Cut out tents and burn.

THE FOREST TENT-CATERPILLAR ${ }^{13}$ (Malacosoma disstria)

Order-Lepidoptera. Manual, p. 362

Life history is similar to former species; larvae do not build tent.

12 Quaintance--U. S. Bu. Ent., Circ. 98.

13 Slingerland-Cornell Univ. Expt. Stat., Bull. 170. 
Control-In addition to above, use the jarring method.

White-MARIED TUSSOCK Mothi ${ }^{14}$ (Hemerocampa leucostigma)

Order-Lepidoptera. Manual, p. 3IO

Lays eggs in July on cocoons and covers them with a white frothy substance; remain here all winter and hatch latter part of May; the caterpillar has two long pencils of hairs just back of the head, a single similar tuft on the posterior end of the body, and four tufts of short white hairs on the back; they feed on leaves and fruit for four weeks and then pupate in cocoons for Io to I4 days; the adult wingless female deposits eggs on cocoons; male is winged.

Apple, pear, quince, plum, elm, maple and other deciduous trees are attacked.

Control-Collect egg clusters; spray with arsenate of lead 3 pounds to 50 gallons; jar trees for caterpillars; band trees for larve.

\section{The apple maGgot ${ }^{15}$ (Rhagoletis pomonella) \\ Order-Diptera}

The flies begin to emerge in the latter part of June and continue through July and August. Within Io days to 2 weeks the females thrust their eges just beneath the skin of the apple, causing a dimple at each insertion. The eggs hatch in 2 to 6 days and the white maggots tunnel through the apple causing it to drop and decay. In about 30 days in soft apples the maggots become grown and then go into the soil from I to 3 inches and pupate, where they usually remain until the next spring. There may, however, be a partial second brood in

14 Schoene-N. Y. State Expt. Stat., Bull. 312.

15 Illingworth-Cornell Univ. Expt. Stat., Bull. 324.

Herrick-Cornell Univ. Expt. Stat., Bull. 402. 
some seasons, while on the other hand the puparia may remain in the soil over another winter, thus making a two-year life cycle.

Control-Spray last days of June or first week of July with arsenate of lead, 5 pounds to 100 gallons of water, and repeat in two weeks. Clean culture of orchards appears to aid in the fight.

The RIBBED COCOON MAKER ${ }^{16}$ (Bucculatrix pomifoliella)

Order-Lepidoptera. Manual, p. 253

In the middle of September larvæ creep to branches and make white, ribbed, winter cases and change to pupe: in May the moths appear and soon lay their eggs on under sides of leaves; they hatch in a week or Io days and mine into leaves; they feed for $S$ or Io days and then emerge from the leaf and make a molting cocoon, molt again in 5 or 6 days, then feed again for a week and then spin true cocoons; moths appear in from $I$ to 2 weeks and lay eggs for a second brood about the first week of August.

Control-Spray in March with lime-sulphur at scale strengths; spray in June with arsenate of lead, $2 \mathrm{I} / 2$ pounds to 50 gallons.

\section{Oyster-sield bark louse ${ }^{1 \tau}$ (Lepidosaphes ulmi)}

\section{Order-Hemiptera}

This insect passes winter as whitish eggs underneath the brown, elongated, oyster-shell like scales on the bark of the tree; eggs hatch in May and June and the young soon settle and secrete their own scale: probably one generation a year in New York.

Control-Spraying with lime-sulphur at scale 16 Slingerland-Cornell Univ. Expt. Stat., Bull. 2I4.

17 Quaintance-U. S. Bit. Ent., Circ, I2r. 
strengths ( I to 8 ) for 3 or 4 successive seasons usually holds this pest in check. Spray for young as they hatch in May or June with nicotine sulphate, $3 / 4$ pint to Ioo gallons water with 4 pounds of soap added or with IO \% kerosene emulsion.

\section{THE WOOLLy APHid ${ }^{1 \mathrm{~s}}$ (Eriosoma lanigera)}

Order-Hemiptera. Manual, p. I62

It is probably of American origin and became noticeable here about I 850 ; most serious on the apple; individuals occur on two different parts of the tree; ( I ) the branches, (2) the roots. The airliving individuals cause scars on limbs but are not considered to be seriously injurious; the root aphids are very injurious to young apple trees when present on the roots; they cause swellings on roots and the roots finally decay and trees die; both kinds of individuals secrete a white cottony secretion, hence the name, woolly aphid. This pest of the apple is more serious farther south than in New York.

The woolly aphid has a complicated life history. Some of the winged forms on apple in autumn fly to elm trees where the egg-laying females are produced, each of which lays an egg in a crevice of the bark where it passes the winter and hatches in the spring. The aphids multiply on the elm and cause the leaves to curl. Finally some of the winged forms may fly back to the apple. In the meantime the aphid has maintained its foothold on the apple tree.

Control-The trunk aphids may be controlled with kerosene emulsion is\%. The root aphids may be controlled with I5\% kerosene emulsion. The earth should be removed about each tree to the depth of 3 or + inches over a circle with a diameter of + feet; then soak the soil with the emulsion and 18 Marlatt-U. S. Bur. Ent., Circ. 20. 
hoe dirt back; do this in late spring when tree is in leaf.

DARK REDBUG ${ }^{19}$ (Heterocordylus malimus)

Light Rediug (Lygidea mendart)

Order-Hemiptera

There are two species of redbugs, the dark redbug and the light redbug, that injure the fruit by puncturing it, which causes it to fall off or become knotty: the life histories of both are quite similar; the eges of both are laid during late June or early July in the bark of smaller branches. They hatch the next spring, those of the dark redhug soon after the leaves of the fruit buds open and those of the light redhug from 7 to to days later. The nymphs pass through five stages and become mature in about one month. There is one generation a year.

Control-Spray for the nymphs with nicotine sulphate, I pint to Ioo gallons of water; the efficiency will be increased by adding + pounds of soap to every Ioo gallons; spray just before blossoms open and after they fall, especially in case of the light redbug. The tobacen may be added to limesulphur and arsenate of lead. The calyx spray of arsenate of lead, lime-sulphur and nicotine has apparently, in some instances, controlled the light redbug.

\section{ApPle-SEed CHALCis ${ }^{20}$ (Syntomaspis druparum) Order-Hymenoptera}

The adult wasp-like fly punctures the fruit to deposit her eggs in the seed and this causes the fruit to become knotty; the ege is deposited inside of an apple seed in Jume; it hatches and the grub feeds on the soft kernel until September; it then hiber-

10 Crosby-Cornell Univ. Expt. Stat., Bull. 29 I.

20 Crosby-Cornell Univ, Expt. Stat., Bull. 265. 
nates in the hollow seed shell until spring, when the adults appear; particularly in jurious to early apples.

Control-Since the grub lives over winter in the seeds, the apples under the tree should all be collected and destroyed.

\section{THE GREEN FRUIT WORMS ${ }^{21}$ (Xylina antemata)} (Xylina laticincrea)

\section{Order-Lepidoptera}

In some seasons the larva of several species of noctuid moths attack apples and eat large holes in the sides of the fruit: these larva have become known as the green fruit worms: the larve appear in great numbers in May and June and do their damage, then go into the soil to the depth of I to 3 inches where they make an earthen cell and spin a thin cocoon and change to pupx ; there they remain until September, when the moths appear and pass the winter in sheltered nooks; some of the pupa remain all winter in the soil. The moths come from their hibernating guarters or from the soil in March and April and lay their nearly globular, ridged egos singly on the apple and pear branches. The larva are not noticed until they become half grown and are then hard to kill.

CONTROL-If the trees are known to be infested they should be sprayed just as the tips of the buds show green and again just before the blossoms open with arsenate of lead, 3 pounds to 50 gallons of water or lime-sulphur.

THE PEAR-LEAF BLISTER-MITE ${ }^{22}$ (Eriophyes pyri)

Order-Acarina

This mite has become a serious pest of apple trees in New York State within the last few years; it is fully discussed under pear pests.

21 Slingerland-Cornell Univ. Expt. Stat., Bull. 123.

22 - Parrott-N. Y. State Expt. Stat., Bull. 283. 
Fruit-tree leaf-Roller ${ }^{23}$ (Archips argyrospila)

\section{Order-Lepidoptera}

Eggs laid in small patches on branches of trees in June; larve hatch next spring and attack buds and roll leaves together and eat into sides of fruit; pupate in rolled leaves with a flimsig cocoon: moths appear in June and July and lay erges in great numbers on the branches where they remain until the following spring. This insect is exceedingly injurious when once established in an orchard. It attacks apples, pears, cherries, and other fruits.

Control-Spray the trees infested with eggs just before the buds start with a miscible oil, I gallon to Is gallons of water. Follow this with arsenate of lead, 3 pounds to 50 gallons just as soon as the tips of the buds show green, and again before the blossoms open. The spraying should be done thoroughly.

\section{Apple curculio ${ }^{24}$ (Anthonomus quadrigibbus)}

\section{Order-Coleoptera}

Mainly injurious in Central States; eggs laid in fruit while small; larvæ feed on tissues of apple for three weeks: pupre formed in apple and after about one week adult beetles emerge.

Control-Spray with arsenate of lead, 3 pounds to 50 gallons just after petals fall and repeat in ten days; clean up old fences and hedgerows near orchard.

\section{Trearet teAF-MINER ".. (Tischeria malifoliella) \\ Order-Lepidoptera. Manual, p. 249}

Figgs laid on leaves; larve gnaw through egg di23 Herrick and Leiby-Cornell Univ. Expt. Stat., Bull. 367.

24 Crandall-Illinois Expt. Stat., Bull. 98.

${ }_{25}$ Quaintance-U. S. Bu. Ent., Bull. 68, Pt. III. Jarvis-Conn. (Storrs) Bull. 45. 
rectly into the leaf and begin making their trumpetshaped mines in the leaves; font generations in latitude of Vashington, probably two here: larve of last generation pass winter in mines in fallen leaves and pupate in spring.

Control_-Plow the leaves under or rake them and burn; spray infested leaves during June with nicotine sulphate, I pint to IOo gallons of water with 4 pounds of soap added.

FALL wEB-wORM ${ }^{20}$ (Hyphantria te.rtor)

Order-Lepidoptera. Manual, p. 32I

Egos laid during June or July in clusters on leaves; larva build web nests all over trees; they pupate in Septenulser in flimsy cocoons hid away in cracks and crevices; in these the pupe pass the winter, the moths appearing in May or June; farther south there are two broods.

CONTROL-Spray with arsenate of lead, 3 pounds to 50 gallons of water as soon as the young caterpillars are seen; collect cocoons during winter.

THE RED-HUMPED APPLE-WORM ${ }^{27}$ (Schizura concinna)

Order-Lepidoptera. Manual, p. 267

Eggs laid in large white clusters on leaves in June and July; larve feed in colonies on a branch: they go to the base of the tree and build parchmentlike cocoons in which they pass the winter; they change to pupa in the spring; the moths emerge in June, July and August.

Control-Burn caterpillars with rag torch or spray with arsenate of lead, 3 pounds to 50 gallons. Make the first application early in July and second about two weeks thereafter.

26 Sanderson-New Hampshire Expt. Stat., Bull. I39.

${ }_{27} 7$ Sanderson-New Hampshire Expt. Statat, Bull. I39: 
YELLOW-NECKED CATERPILLARS ${ }^{28}$ (Datana ministra)

Order-Lepidoptera. Manual, p. 265

Eggs laid in large white clusters in June and July; larva are gregarious, and often occur in large clusters on single branches; pupate in the earth in August and September, where they remain until the following spring; moths appear in June and July.

Control-Same as for the red-humped caterpillars.

THE PALMER-WORM ${ }^{29}$ (Ypsolophus ligulcllus)

\section{Order-Lepidoptera}

This is an insect that appears occasionally in injurious numbers; the larve destroy foliage and eat into fruit during June; moths appear first part of July and live over winter until following spring; eggs laid mostly on undersides of leaves.

Control-Spray with arsenate of lead, $2 \frac{\mathrm{T}}{2}$ pounds to 50 gallons when petals have three-fourths dropped and again in three weeks.

Buffalo TreE-HOPPER ${ }^{30}$ (Ceresa bubalus)

Order-Hemiptera

Eggs laid most commonly in early September in siits made in the bark of branches; characteristic oval scars are left; eggs hatch in April or early May; the nymphs feed on succulent weeds in orchard; branches of affected trees become weakened and break off.

Control-Clean culture in and about the orchard to starve nymphs; careful and judicious pruning of infested branches.

The PLUM CURCULIO-An important enemy to the apple. It causes lnotty, scarred fruit and is

28 Sanderson-New Hampshire Expt. Stat., Bull. I39.

20 Slingerland-Cornell Univ. Expt. Stat., Bull. I87.

30 Hodgkiss-N. Y. State Expt. Stat., Tech. Bull. I7. 
apparently increasing as a pest to the apple. See plum pests for full discussion.

\section{OTHER INSEC'IS INJURIOUS TO THE APPLE}

The apple weevil (Psendanthonomus cratcei).

The fringed-wing apple bud-moth (Holcocera maligemmella).

The apple bud-worm (Exartema malamm).

The oblique banded leaf-roller (Archips rosace. ana).

The leaf-crumpler (Mineola indigenclla).

The lime-tree span-worm (Eranmis tiliaria).

Bruce's measuring-worm (Rachela bruccata).

The oypsy moth (Porthctria dispar).

The brown-tail moth (Euproctis chrysorrhaca).

The apple leafhopper (Empoasca mali).

The bronze apple-tree weevil (Magdalis cnescens).

\section{PLUM PES'TS}

At least 50 species of insects may feed upon the plum tree and its fruit.

Tue plum CURCulio ${ }^{31}$ (Conotrachelus nemphar)

Order-Coleoptera. Manual, p. 593

The adults hibernate in protected places along hedgerows, fences, etc., and appear in spring; they feed upon fruit, making slallow circular feeding punctures; they som begin depositing egos in the fruit, making a crescent-shaped cut beneath each egg; eggs hatch in 4 to Io days and live in the fruit for about I4 days; the fruit usually falls to the ground and the grubs enter the soil from I to 3 inches and pupate: in July and August the adults

${ }^{31}$ Crandall--Illinois Expt. Stat., Bull. 98.

Quaintance and Jenne-U. S. Bu. Ent., Bu1l. Io3. 
appear and eat holes in the sides of apples, at least; these holes are usually surrounded by a dark ring of skin; beetles finally hibernate. This pest attacks apples, cherries, plums, pears.

Control-Remove all fences, hedgerows, stone walls, etc., along sides of orchard; sumlight is fatal to larve, hence judicious pruning of trees and clean cultivation useful; cultivate orchards in July and August to kill pupa; spray with arsenate of lead, 5 pounds to roo gallons of water just after petals fall and again ten days later.

\section{Plum scale ${ }^{32}$ (Lecanim comi) \\ Order-Hemiptera}

Eges are laid in May and June and hatch mainly in July; the young insects live on the leaves during the stimmer but migrate to the branches in the fall before the leaves drop; the young hibernate here, but in the spring usually move to the smaller branches where they complete their growth by the latter part of May.

Control-Spray young scales about July ist with ro\% kerosene emulsion or nicotine sulphate, I pint to IOo gallons of water with + pounds of soap added; spray young scales on branches just before buds burst with a miscible oil, I gallon to I 5 gallons water.

\section{THE PLUM GOUGER ${ }^{33}$ (Anthonomus scutcllaris) Order-Coleoptera}

Occurs particularly in the Northern Mississippi Talley. Adults hibernate over winter and appear in early spring, when they feed on buds and leaves: later make feeding punctures in fruit and finally deposit eggs in cavities dug in fruit; larva bore into

32 Slingerland-Cornell Univ. Expt. Stat., Bull. 83.

${ }^{33}$ Cooley-Mon. Expt. Sțat., Bull. 62. 
pit and feed on kernel; change to pupre in pits and beetles emerge in August and September; principal injury caused by punctures made by beetles in feeding and egg-laying.

Control-Probably thorough spraying with arsenate of lead will be effective. The first application should be made just before the blossoms open.

\section{OTHER INSECTS INJURIOUS TO THE PIUM}

Plum leaf-miner (Nepticula slingerlandella).

American plum-borer (Eusophera semifunerralis).

Plum web-spinning sawfly (Neurotoma inconspicua).

Plum plant-louse (Myzus mahaleb).

Rusty brown plum aphid (Aphis setarice).

Mealy plum louse (Hyalopterus armindinis).

European fruit-tree scale (Aspidiotus ostreceformis).

\section{PEAR PESTS}

The PEAR-LEAF BLISTER-Mite ${ }^{3:}$ (Erioplyyes pyri) Order-Acarina

This is an European pest originally confined to the pear but now an important pest on apple in New York; it is a small, light-colored, four-legged animal about I-I 25 of an inch in length; it hibernates in the buds beneath the bud-scales; in the spring the mites become active and go to the unfolding leaves into which they burrow and make small. brown, almost black, galls or blisters on them; the mites live inside the galls in the tissues of the leaves and lay their eggs there; the young are produced in the 34 Parrott-N. Y. State Expt. Stat., Bull. 306. 
galls but emerge later and form other blisters; affected leaves turn yellow and drop, thus injuring the tree.

Control-Spray trees in fall or spring with lime-sulphur, I gallon to Io or I2 of water.

The PEAR PSylla ${ }^{35}$ (Psylla pyricola)

Order-Hemiptera. Manual, p. I56

A very fluctuating pest introduced from Europe upon young pear trees about $I_{32} 2$; very injurious in central and western New York and along the Hudson; the orange-yellow eggs are deposited in creases in the bark mostly before the buds burst; the eggs hatch usually during the first two weeks of May; the nymphs suck juices from leaves and stems of young fruit; they secrete great quantities of honey-dew in which a fungus thrives and forms a black coating all over the branches; the nymphs mature in about one month and the adults appear; there may be four broods in a season; the adults of the last brood winter over in the crevices of the bark.

Control-Scrape rough bark from trees and spray in November or December or March or early April with nicotine sulphate, $3 / 4$ pint to Ioo gallons and 5 pounds of soap; miscible oil may also be used at the rate of I gallon to I5 of water; spray on warm days when the temperature is not freezing; spray last of April or early May as buds are bursting with lime-sulphur at winter strengths to kill eggs. Spray for nymphs with "black-leaf 40," $3 / 4$ pint to IOO gallons with 5 pounds of soap; practice clean culture.

35 Slingerland-Cornell Univ. Expt. Stat., Bull. 44.

Hodgkiss-N. Y. State Expt. Stat., Bull. 387. 


\section{The PEAR SLUG ${ }^{36}$ (Caliroa cerasi) \\ Order-Hymenoptera}

Eggs laid in June in the leaf, hatch in 2 weeks and the slugs become full-grown in + or 5 weeks, when they shed their green skin for a yellow one and go into ground to pupate; the flies emerge in about 2 weeks; two broods of the slugs, first in June and second in August; hibernate as contracted slugs in their cocoons in soil.

Control-Spray with arsenate of lead, $2^{\mathrm{T}} / 2$ pounds to 50 gallons of water, when slugs are first seen.

\section{The SAN JOSE SCALE ${ }^{37}$ (Aspidiotus perniciosus) Order-Hemiptera}

One of our worst pests on fruit trees; first established in this country at San José, Calif.; widely distributed over the United States, and infests apple, peach, pear, plum, currant, etc.; first described by Professor Comstock in I 880 : first discovered in the eastern United States in IS93; its original home is in China. (The insects pass the winter in an immature form-three-fourths grown-on the branches of infested trees under small, circular, almost black scales; young are born in the spring, in June, for first generation; often but two generations a season in New York State.

Control-Spray with lime-sulphur, I gallon to 8 of water, fall and spring; spray old rough-barked trees with one application of $25 \%$ oil emulsion; summer strengths of lime-sulphur are effective when young are hatching.

${ }^{36}$ Marlatt-U. S. Btı. Ent., Circ. 26.

${ }^{37}$ Quaintance-U. S. Bu. Ent., Circ. 124.

Britton-Conn. Expt. Stat., Bull. I65. 
THE SCURFY BARI-LOUSE ${ }^{38}$ (Chionaspis furfura) Order-Hemiptera

The female scales are large, elongated and dirty white: the male scales are small, long and narrow and have three ridges rumning lengthwise; the female matures toward fall and lays 60 to so pur= plish eggs beneath the scale which remain there until the following spring; the female gradually shrivels and dies as she lays her eggs; there is one brood a year; this pest occurs on apple as well as pear, but it is not considered seriously injurious.

Control-Spray when the eggs are hatching and the young are appearing with nicotine sulphate, I pint to IOO gallons of water with 4 pounds of soap, or with whale-oil soap, I pound in 5 gallons of water.

\section{The PEAR MIDGe ${ }^{39}$ (Contarinia pyrivora) Order-Diptera}

The adult insects which resemble miniature mos(fuitoes, and are related to the Hessian fly, appear in the spring when the buds are bursting and lay their eges through the petals and calyx on the anthers of the unopened flowers: eggs hatch in 4 or 5 days; the maggots work their way to the core of the developing pear and eat into the flesh in all directions; they cause the fruit to become misshapen; when the maggots are full-grown, about June Ist, the pears crack open and allow them to escape to the ground, where they change to pupe and remain in the ground all winter; one brood a year; now occurs in Connecticut. New York and New Jersey, being confined to the Hudson River V alley in New York.

${ }^{38}$ Quaintance and Sasscer-U. S. Bu. Ent., Circ. I2I.

39 Smith-N. J. Expt. Stat., Bull. 99. 
Control-Pick and destroy all misshapen infested fruits before May I 5 th; use kainit, one-half ton per acre.

\section{TIIE PEAR THRIPS ${ }^{40}$ (Euthrips pyri) Order-Thysanoptera}

The thrips was first discovered in California, where it has caused much injury ; it was first discorered in New York in the Hudson River Valley in ig) I, although probably had been present there for some years before: the thrips pass the fall and winter in the soil and the adults appear in the spring; they injure the opening huds and lay their esoss in the tissues of the fruit stems and leaves; the nymphs feed mainly on the young leaves; after feeding about two weeks they go into the ground but do not change to pupe until about October.

ControL-Spray swelling, partly open and fully opened buds with nicotine sulphate, $3 / 4$ pint to Ioo gallons water and 5 pounds soap; spray on successive days or every few days until probably 2 or 3 applications have been made.

\section{ThE SINUATE PEAR BORER ${ }^{* 1}$ (Agrilus simuatus) Order-Coleoptera}

First discovered in New Jersey in IS94; now seriously injurious in lower Hudson Valley; the female deposits her egos in crevices of the bark or under the bark scales; these hatch in early July and the slender whitish artuls malie winding burrows in the sapwood; the larva rests during the winter but the next year it makes larger and nore winding burrows which frequently cut off the supply of sap and kill the tree; the larva passes another winter in the tree changing to a pupa in the fullowing spring;

40 Parrott-N. Y. State Expt. Stat., Bu1l. 343.

11 Smith-I5th Ann. Rept. N. J. Agr. Expt. Station. 
the slender bronze-brown beetles emerge the last of May and during June.

Coxtron-Adults feed on leaves, which sugerests spraying with arsenate of lead after the petals fall; the spraying should be continued during successive years.

\section{The FALSE TARnished PLANT-BUG ${ }^{42}$ (Lygus} communis)

Order-Hemiptera

This insect has for years caused more or less injury to pears in New York State; the nymphs puncture the young fruit, thus causing it to become deformed and knottr: the tissue surrounding the puncture becomes hardened and gritty; the eges are deposited in the young pear branches.

The adult is about $\mathrm{T} / 4$ inch in length, very similar to the tarnished plant-hug and is light brownish in color; the winter seems to he passed in the egg stage.

Control-Spray about the time the petals are falling with nicotine sulphate, 3 - pint to $r$ oo gallons of water to which are added 3 or 4 pounds of soap. Repeat, if necessary, a few days later.

OTIIER IXSLCTS INJURIOTS TO TIIE PEAR

Pear-blight beetle (Xyleborus dispar).

Codling moth (Carpocapsa pomonella)

Green fruit-worm (Xylina antemnata). San José scale (Aspidiotus perniciosus).

Cigar case-bearer (Coleophora Actcherella).

Howard scale (Aspidiotus howardi).

Fruit-tree leaf-roller (Archips argyrospila).

\section{PEACH PESTS}

It least 25 different insects attack the peach tree. 12 Parrott and Hodgkiss-N, Y, State Expt. Stat., Bull. 368. 
The PEACH-TREE BORER ${ }^{43}$ (Samminoidea exitiosa)

Order-Lepidoptera. Manual, p. 260

This pest is found in every state where peaches are grown east of the Rocky Mountains; it is a native insect and may attack the cherry, plum, prune, apricot, almond, and nectarine.

The eggs are deposited on the bark of the trunks of trees in July and later; they hatch and the young larva find a crevice through which they gnaw their way into the inner bark; here they work in the inner bark and sapwood, usually just below the surface of the ground; they often girdle young trees; the borers become half or two-thirds grown by fall and hibernate, either in their burrows or in hibernacula until spring; they become active and complete their growth by first part of June in New York and transform to pupæ; some larvæ seem to live over another year; the larva make large cocoons at the surface of the ground and the moths emerge from latter part of June to August; the moths are clear-winged, shy and not often seen; the female has one or two orange-yellow bands on abdomen.

Control-Dig out the borers before June i 5 th of each year; Smith says, after borers are dug, spray the trunks with lime-sulphur at winter strengths with an excess of lime added and with I pound arsenate of lead to 5 sallons of the mixture. Spray with force into crevices of lark and then hill up 6 inches around base of tree; gas tar is sometimes used but some danger in it. Paradichlorobenzene is being used in an experimental way ( $U$. S. Bu. Ent., Bull. 796).

43 Slingerland-Cornell Univ. Expt. Stat., Bull. I76.

Smith-New Jersey Expt. Stat., Bull. 235. 
THe black PEACII APIIID ${ }^{44}$ (Aphis persica-niger) Order-Hemiptera

The full-grown aphicls are black but the younger ones are reddish-yellow or amber in color; the lice appear early in the season and confine their attacks to the tender bark of the twigs; later they attack the blossoms and blight them; they also attack the young peaches causing them to wilt and drop; the leaves also curl; the aphids leave the branches in the latter part of June; they are said to pass the winter on the roots of the tree reinfesting the tree again in spring; this species often gets into this state on trees from nurseries in New Jersey, Naryland, etc.

ConTRol-Repuire nursery stock to be fumigated or dip the roots after freeing them from dirt in I5\% kerosene emulsion for 2 mimutes only or in nicotine sulphate, I ounce to 5 gallons of water.

The fruit-tree bark-Beetle ${ }^{45}$ (Scolytus rugulosus)

\section{Order-Coleoptera}

Peach, cherry, plum and apple trees are often found with many small, round holes in the bark of the trunks and branches, due to the attacks of this small black beetle about one-tenth of an inch long; when trees are first attacked masses of gum exude; diseased or weakened trees are most liable to attack but healthy trees are also subject to attack; the parent beetle bores through bark and excavates a burrow beneath, along the sides of which she digs tiny niches in each of which an egg is deposited; the eggs hatch and each grulb excavates a long burrow as it grows but finally changes to a pupa and the adult emerges cutting a round hole in the bark; at least two generations a year; passes the ${ }_{44}$ Slingerland-Cornell Univ. Expt. Stat., Bull. 49, p. 325.

${ }^{45}$ Chittenden-U. S. Bu. Ent., Circ. 29. 
winter as a larva; very injurious and hard to control; also called the shot-hole borer.

Control-Maintain vigorous healthy trees by proper cultivation and fertilization; cut down and burn all trees beyond hope and cut off all badly infested branches from other trees; clean up hedgerows on the borders of orchards; apply thick coat of whitewash three times a year to protect trees, last of March, first part of July, and first of October.

\section{The PEACH-TREe BARK-BEETLE ${ }^{46}$ (Phlocotribus} liminaris)

\section{Order-Coleoptera}

This is another species very similar in appearance to the former, works in much the same way on peach trees but not so prevalent in New York; hibernates as adults in cells just beneath outer layer of bark on both healthy and unhealthy trees; in early spring they come out and migrate to trees, wood piles, brush heaps, etc., wherever they can build their brood chambers; 2 broods a year.

\section{TiIE PEACH TWIG-BORER ${ }^{47}$ (Anarsia lineatella) Order-Lepidoptera}

Apparently not a serious pest here; more serious farther" south and in California; the half-grown larva hibernate in cells just under the outer bark, mainly in crotches of the branches; in the spring the larve emerge and attack the new leaf shoots into which they burrow; there are several broods a season some of which attack the stems of the fruit and some the fruit itself; the last brood of larva go into hibernation in cells in the bark; the

46 Wilson-U. S. Bu. Ent., Bull. 68, Pt. 9.

47 Marlatt-U. S. Dept. Agr., Far's' Bull. So.

Clarke-Calif. Expt. Stat,, Bull. I44. 
moth is only a little over half an inch in expanse of wings and of a dark grey color.

Control-Lime-sulphuir I to Io and I to I I applied in the spring after the buds have begun to swell seems effective in California and Colorado; also arsenate of lead, 5 pounds to 50 gallons, applied when the majority of the blossom buds are showing their pink tips seems effective in Colorado.

\section{GreEN PEACH ApIIID ${ }^{48}$ (M j'alls persice)}

\section{Order-Hemiptera}

Described under a multitude of names; feeds on 60 different plants; most abundant peach louse; spends winter in ege stage on tree; egos hatch in early spring and young go on the buds; the third generation leaves for other plants.

Control-Spray with nicotine sulphate, $3 / 4$ pint to Ioo gallons of water with 4 pounds of soap or with whale-oil soap, I pound to 5 gallons or with IO \% kerosene emulsion.

Tine PEACH LeCANium ${ }^{* 9}$ (Lccanium nigrofasciatum $)$

Order-Hemiptera

The "Terrapin scale" affects peach, plum, apple, maple, sycamore, linden, and birch; it winters as an immature female on the branches; these mature early in spring and bring forth the young; the young go to the leaves and continue their growth slowly until fall when they hibernate; only one generation a year; this insect is apparently not abundant in New York; affected trees take on a sooty appearance due to a black fungus that flourishes in the honey-dew excreted by the insects.

Control-Lime-sulphur is not effective; kero-

48 Gillette-Colo. Expt. Stat., Bull. I33.

49 Sanders-U. S. Bu. Ent., Circ. 88. 
sene emulsion 20 to $25 \%$ applied just before buds burst will kill the hibernating females; the miscible oils I to I6 or 20 just before the buds burst are effective; ${ }^{50}$ an emulsion of linseed oil and gasoline applied at the same period of tree development as recommended for the miscible oils has been very satisfactory; the emulsion is made by dissolving 2 pounds of soap in 4 gallons of hot water and then adding 5 gallons of raw linseed oil and 3 gallons of gasoline and thoroushy emulsifying the whole; then add 88 gallons of water.

\section{ThE TARNISHED PLANT-BUG ${ }^{51}$ (Lygus pratensis)}

\section{Order-Hemiptera}

This widespread bug evidently attacks the fruit of peaches in some years puncturing the epidermis and scarring the surface of the fruits; as a result gum exudes and the peaches soon become unfit for the market; the bug evidently attacks mostly peaches on trees standing in uncultivated orchards or about the edges of orchards among grass and weeds; it is very injurious to young peach trees in the nursery row; it punctures the buds and tender growing tips thus producing a stunted straggling young tree; it also attacks apples causing dimples in them.

The adult is a dull yellowish or greenish bug mottled with reddish-brown and about one-fifth inch in length; the eggs are inserted in the tender tips or petioles and veins of leaves; the life cycle is probably about 45 days and there are probably several generations a year.

ConTRoL-Clean cultivation is the only known method of control.

50 Simanton-U. S. Bu1. Ent., Bull. 35I.

51 Crosby and Leonard-Cornell Univ, Expt. Stat., Bull. 346. 
The ORIENTAL PEACH MOTH ${ }^{52}$ (Laspeyresia molesta )

\section{Order-Lepidoptera}

The oriental peach moth has lately been discorered in this country and promises to be a serious pest. It occurs in New York, New Jersey, Maryland, Iirginia, and Connecticut. It injures plum, cherry and peach at least.

The insect passes the winter as a larva in cocoon beneath flakes of bark; these pupate in early spring and moths emerge in mid-April in Maryland: the moths lay their eggs singly on undersides of leaves and the larva attack tender shoots; the larve feed 8 to 16 days and spin cocoons in axils of twigs; the pupal stage lasts 5 to I 2 days; there are 5 generations in the vicinity of Washington, D. C.; the fourth brood larve feed on the fruit of late ripening varieties.

Control-Winter applications of lime-sulphur are useful; applications of the neutral arsenate of lead, 2 pounds to 50 gallons will aid in control; legin spraying with dropping of the bloom and make three applications about one month apart; watch effect of applications as arsenate of lead is liable to burn foliage; use extra lime or add to the self-boiled lime-sulphur.

The Plum CURCUlio ${ }^{53}$ - An important pest on peaches because it not only punctures the fruit but carries the spores of brown-rot and makes wounds through which the brown-rot enters. The selfboiled lime-sulphur for control of brown-rot with arsenate of lead added at the rate of 2 pounds to 50 gallons of the mixture has given good results in the control of this pest. The arsenate of lead combined with the self-boiled lime-sulphur does not

52 Garman-Md. Expt. Stat., Bull. 209.

53 Scott and Quaintance-U, S. Bu. Ențt., Circ. I20, 
seem to be as injurious to peaches as when used alone. The first application should be made about the time the calyces or shucks are falling and the second two or three weeks later. It is doubtful if a third application of poison is advisable.

The San Jose scale-Very injurious to peach trees; discussed under pear pests.

\section{O'THER IXGLCTS MNJUIOTS TO TIE PEACII}

Lesser peach-tree borer (Symanthedon pictipes).

White peach scale (Aulacaspis pentagona).

Fruit-tree leaf-roller (Archips argyrospila).

Apple-tree tent-caterpillar (Malacosoma amoricana).

Peach saw-fly (Pamplitius persicus).

\section{QUINCE PES'IS}

The guince CuRculio ${ }^{54}$ (Conotrachelus cratcgi) Order-Coleoptera

This insect is a native one and its natural food is the hawthorn; it also attacks pears and is widely distributed throughout the eastern, central, and extreme western portions of the United States.

The winter is passed in the grub stage in small cells 2 or 3 inches below the surface of the earth; the grubs change to pupx in the spring; the beetles appear from last week in May in some seasons to last week in July in others; the beetles feed on young fruits for some days and then deposit their egos in the frutit the larve feed on the tissues of the fuinces and when full-grown emerge through a hole and drop to the ground.

Control_— ${ }^{55}$ Spray first as soon as beetles be54 Slingerland-Cornell Univ. Expt. Stat., Bull. r48.

55 Strickland and Achilles-N. Y. State Dept. Agr., Bull. II6. 
sin to feed which will be during the first two weeks of July, usually, with Bordeaux 3-3-50 or limesulphu1 I-40 with 3 pounds of arsenate of lead added to each 50 gallons of liquid; make a second application in about a week or ten days; collect all drops and culls, take them from the orchard, and destroy them.

TIIE BUD MOTH-This is also quite a pest of quinces; discussed under apple pests.

THE PEAR SLUG-This occurs on quince trees but may be controlled as reconnmended under pear pests.

TiIE CODLING MOTH-This common apple pest is often quite a serious pest in quinces; it can doubtless be controlled as on apples.

TIE ROUND-HEADED APPLE-BORER-This is seriously injurious to quince trees but is subject to the same methods of control as on the apple.

\section{CHERRY PESTS}

As many as 46 different pests may attack the cherry tree.

TIIE BLACK CHERRY LOUSE ${ }^{56}$ (My心us cerasi)

Order-Hemiptera

This is an old European pest and has been here for at least 50 years; it is primarily a pest of sweet cherries and although in some localities it may attack sour cherries it does not seem to seriously injure them; the eggs are laid on the small branches about the buds; the young lice appear about the time the buds open on sprouts and lower limbs of trees; the lice increase all throush June until sometimes they become rery abundant; then they nearly all disappear, most of them going to the wild pepper-grass (Lepidium apctalum), only scattered

${ }^{56}$ Gillette-Canad. Ent., Vol. 50, p. 24I. 
colonies remaining here and there; in September winged forms return from the pepper-grass and the egg-laying females deposit their eggs; the cherry foliage may sometimes be blackened with these lice; the winged and wingless forms are deep shining black and the body is rather broad and flat; they curl leaves badly.

Control-Spray with nicotine sulphate, $3 / 4$ pint to IOO gallons of water with 4 pounds of soap added before the buds break; spray thoroughly.

THE CHERRY FRUIT-FLIES ${ }^{57}$ (Rhagolctis cingulata) (Rhagoletis fausta)

\section{Order-Diptera}

These flies are very similar in appearance to the apple maggot $\mathrm{fly}$; the eggs are inserted beneath the skin of the cherries a short time before they begin to redden; infested cherries do not show any effects of the egg laying or of the maggot within for some days; when cherries are left on the tree or picked a portion of each fruit will rot and sink in on the side; the maggot is yellowish-white and a little over a quarter of an inch long; it is straight while the larva of the curculio that lives in cherries is usually more or less curved; the maggots leave the fruit when full-grown and enter the sround where they change to pupe and remain until the following spring; there is only one brood a year; the insects are confined mainly to sour varieties of cherries.

Control-Spray with arsenate of lead, 5 pounds, water Ioo gallons, and 2 gallons of molasses; apply just as cherries begin to redden or when flies first appear; if it rains repeat in a week or ten days. There is evidence to show that arsenate of lead alone in water will control the insects.

57 Slingerland-Cornell Univ. Expt. Stat., Bull. 172.

Illingworth-Cornell Univ. Expt. Stat., Bull. 325. 
TIIE CIIERRY-TREE LEAF-ROLLER ${ }^{58}$ (Archips cerasivorana)

\section{Order-Lepidoptera}

This pest is often seen on choke cherries; the eggs are laid in patches on trunks or branches near the ground; they remain here unhatched until the following spring: when they hatch the green larve crawl up to the branches where they begin to draw the leaves toward each other and tie them together with silk; in this way they build large ugly nests, inside of which they live and eat the leaves; the larve pupate in these nests and the moths appear in June and July; one brood a year.

Control-Cut out nests and burn before moths appear.

Cherry leaf-Miner ${ }^{59}$ (Profemusa collaris)

\section{Order-Hymenoptera}

The larvæ mine in the leaves of cherries; interior of leaves all eaten out and leaf then turns brown and a large "blister" is formed; principal damage occurs during last week of May and early part of June; the larvæ go into ground to hibernate.

Control-Plow and cultivate ground in late fall to destroy larva; pick off the infested leaves and destroy them.

SiIOT-IIOLE borer--Discussed under peach pests. It is often a serious pest on cherries.

THE PEAR SLUG-Often a serious pest on cherries; discussed under pear pests.

The Plum Curculio-Often a serious pest on cherries; discussed under plum pests.

Control-Spray sour cherries with arsenate of lead, 3 pounds to 50 gallons just after petals fall as the young cherries are bursting through the calyces;

58 Herrick-Cornell Univ. Expt. Stat., Buil. 3I I, p. 290.

59 Parrott and Fulton-N. Y. State Expt. Stat., Bull. 4II. 
sweet cherries may need to be sprared twice, ten days apart.

\section{O'THER INSEC'TS INJURIOUS TO THE CHERRY}

Cherry fruit-sawfly (Hoplocampa cookci). Forbes' scale (Aspidiotus forbesi).

Fruit-tree leaf-roller (Archips argyrospila). Oblique banded leaf-roller (Archips rosaceana). 


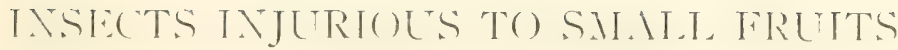

\section{GRAPE PESTS}

Over Ioo insects recorded in this country on the vine.

The grape pitylloxera ${ }^{1}$ (Phylloxera vastatrix) Order-Hemiptera

This insect has always existed in this country on wild vines but not very injurious here; very destructive in France; it exists in two forms, one on the leaves and one on the roots; the root form is much the more injurious one.

The true sexual eggs are laid in the fall on old wood and hatch the following spring; the young lice go to the leaves and form galls on the lower sides; in these galls a female may lay 500 or 600 eggs; there may be 6 or 7 generations a season on the leaves; young of later generations pass to roots and winter there; the root-forms cause galls on the roots and great injury: winged females issue from cracks in the soil in fall and go to the stems of vines where they lay 2 to 8 eggs; these eggs are of two sizes, the smaller yielding males and the larger females; the true females are small with rudimentary mouthparts and each lays a single true egg.

${ }^{1}$ Marlatt-U. S. Dept. Agr., Far's' Bull. 7o.

Quayle-Calif. Expt. Stat., Bull. I92. 
Control-In France American root-stocks are used.

The Grape ROOT-WORM ${ }^{2}$ (Fidia viticida)

\section{Order-Coleoptera}

The most serious pest of the grape in this state; probably invaded (hautauqua grape region about I899; it is an American insect and widely distributed over the northern half of the eastern United States.

The adult beetles appear last of June or first of July and begin feeding on leaves making characteristic chain-like holes; about middle of July they begin to deposit eggs in masses under the loose bark on the canes and trunks; the eggs hatch in about two weeks and the larve drop to the ground where they make their way to the roots through cracks and crevices of the soil; they live upon the roots and become nearly and sometimes full-grown by fall; in November the larvæ burrow to a depth of a foot, form cells in the soil and pass the winter; in early May they return to the roots, feed a short time and change to pupre along in the middle of June; the partly grown larve may feed longer; the pupal stage lasts about two weeks when the adults appear, thus making one generation a year.

Control-Cultivation about the roots of the vines with a horse-hoe during the first two weeks of June is of benefit in destroying the pupæ. If beetles are only moderately abundant, spray vines within one week after beetles are first seen with 6 pounds of arsenate of lead in Ioo gallons Bordeaux; if beetles abundant, use the sweetened mixture of six pounds arsenate of lead, Ioo gallons water and

2 Slingerland-Cornell Univ. Expt. Stat, Bull. I84.

Hammar-U. S. Bu. Ent., Bull. 89.

Hartzell-N. Y. State Expt. Stat., Bull. 33 I. 
2 gallons molasses; rains will wash this mixture off and it must be repeated to be effective.

THE GRAPE-YINE FLEA-BEETLE ${ }^{3}$ (I I altica chalyléa)

\section{Order-Coleoptera}

Another American pest of grapes that in many years is very serious; the first pest, usually, to appear in the spring on grapes; widely distributed over the eastern United States.

The adult steel-blue beetles appear early and attack the swelling buds which they may completely destroy; when leaves appear they feed on them; the beetles lay their eggs all through May under the bark on the canes, under the scales surrounding the buds and occasionally on the leaves; egos hatch latter part of June or early July; the larvæ then feed on foliage and attain their growth in about three weeks; they then drop to the ground and burrow downward several inches where they form cells and change to pupre; the pupal stage lasts io days to two weeks; the beetles emerge and feed upon the foliage but do little damage; they finally enter hibernation along hedgerows, borders of woods, etc., where they pass the winter.

Control-Collect adults in pans with a shallow layer of kerosene in bottom; it is as economical as spraying vines; if no rains, spray vines, when beetles begin to appear, with arsenate of lead, 6 pounds water, Ioo gallons and molasses, 2 gallons; later spray vines with arsenate of lead 3 pounds in 50 gallons of water or Bordeaux mixture.

TIIE ROSE-CIIAFER * (Macrodact ylus subspinosus)

\section{Order-Coleoptera}

This is an American insect and is injurious to

${ }^{3}$ Slingerland-Cornell Univ. Expt. Stat., Bull. I57.

Hartzell-N. Y. State Expt. Stat,, Bulls. 33I, 453.

${ }^{4}$ Hartzell-N. Y. State Expt. Stat., Bull. 33I. 
srapes, cherries, apples, raspberries, roses and other plants; a very serious pest on grapes but is liable to occur locally; the adult beetles feed on the blossoms and when these are gone, on the leaves and berries.

The adult beetles appear during the latter half of June, mate, and deposit their egos the last of June and through July; the eggs are deposited in sandy soil where they hatch and the white grubs feed on the roots of grasses; the grubs become full-grown by November and burrow down about one foot where they pass the winter; early in the spring they crawl back nearer the surface, feed for a time and change to pupx during the latter part of May; in about three weeks the beetles appear. So far as observed these insects prefer sandy soil for breeding and develop largely in grass lands especially long-standing meadows.

Control-Harrow the soil in which larva are present making three harrowings from the last week in May to the middle of June; spray vines with arsenate of lead, 8 pounds to Ioo gallons with two gallons of molasses added; apply as soon as beetles first appear on the vines; it is said that a mixture of whale oil soap, 20 pounds, water, Ioo gallons, and crude carbolic acid, I pint, will kill the beetles when hit and that this mixture will not injure apple and cherry foliage.

TiIE GRAPE LEAFHOPPER ${ }^{5}$ (Typhlocyba comes)

\section{Order-Hemiptera}

This leafhopper is often erroneously called "thrips"; it is an American insect and appears to be found wherever the grape grows; it is becoming of more importance but fluctuates in abundance

5 Hartzell-N. Y. State Expt. Stat., Bu1l. 344.

Johnson-U. S. Bu. Ent., Bull. 97, Pt. I.

Slingerland-Cornell Univ. Expt. Stat., Bull. 215. 
and injurionsness: vines injured hy the hoppers for several years have a stunted growth and bear few grapes.

The adults appear before the leaves have unfolded and feed mutil the middle of June when they begin to deposit their eges within the tissues of the leaves; the egos hatch during the first two weeles of July and the nymphs pass through five stages and many become adults by August ist; they remain on vines until the autumn when they leave to find hibernating places; srassy ditch-hanks, fence corners, hedgerows, and similar situations furnish hihermating opportunities; there is one full hroud, a partial, and sometimes a full second brood; the nymphs live mostly on the under sides of the leaves.

Control-Nicotine sulphate, I to Iooo to I600 is an efficient remedy. It must be sprayed on the under sides of the leaves to be effective. Use a large aperture in the nozzle and a pressure of I 25 to I 50 pounds.

THE GRAPE-BERRY Moth ${ }^{6}$ (Polychrosis viteana)

\section{Order-Lepidoptera}

Nearly all wormy grapes in New York are caused by the caterpillars of this moth; the moth is purplish-brown with not quite half an inch spread of wings; infested berries show a purplish spot on their green surfaces and soon crack open at this place; spores of fungi enter and cause the berries to rot.

The insect spends the winter as a pupa in cocoons attached to the fallen leares: moths begin to appear about June rst and lay their eges preferably on the young berries; the young caterpillars feed on the small berries, often slightly welbing then torether: this spring brood of larva is hardly noticed by

${ }^{6}$ Johnson and Hammar-U. S. Bu. Ent., Bull. Ir6, Pt. II, 
growers although they may destroy much setting fruit; the larva make cocoons on the leaves and some transform to moths that appear latter part of July; these moths lay eggs on the grape berries and these larve go into the berries and cause the wormy grapes; the larve mature in Sept. and make coconns on the leaves; these fall to the ground where the pupæe pass the winter.

Control-Spray with the following mixture, first just after the blossoms fall, second, about two weeks later or when the grape berries are just touching: arsenate of lead 3 pounds, resin fish-oil soap I pound, added to liordeaux $3-3-50 .^{7}$

ThE GRAPE-BLOSSOM MIDGE ${ }^{8}$ (Contarinia johnsoni) Order-Diptera

This insect has been injurious in certain vineyards in Chautauqua County for several years; it is most injurious to early varieties; the larvæ live inside of the blossom buds and injure them by feeding upon the pistil; infested buds become much swollen and blasted.

Adults emerge from soil the latter part of May and deposit their eggs within the buds by means of a long telescopic ovipositor; the larva attain their growth a few days preceding blossoming and then crawl out of the bud; they drop to the ground and burrow beneath the surface where they form cocoons and remain until the following spring when they change to pupæ.

Control-No efficient method of control known. THE GRAPE LEAF-FOLdER ${ }^{9}$ (Desmia funcralis)

\section{Order-Lepidoptera}

In midsummer and later, many grape leaves may

7 Iseley-U. S. Bu. Ent., Bull. 550.

${ }^{8}$ Hartzell-N. Y. State Expt. Stat., Bull. 33I.

9 Strauss-U. S. Bu. Ent., Bull. 4 I9. 
be found with the edges rolled or with the upper faces folded together; if opened a small active wriggling larva will be found between the folds; the leaf will also be found to be skeletonized inside of the folds.

The insect passes the winter as a pupa in the leaves; the moths appear early in the spring and there are at least two broods a season; the moth expands about one inch and has shining black wings bordered with white and with two white spots on each front one and one long white spot on each hind one.

Control-Crush larva by hand in folded leaves; spray with arsenate of lead as for the berry moth and others.

The STRIPED trEe-CRICKeT ${ }^{10}$ (Oecanthus nigricormis)

\section{Order-Orthoptera}

This species of Oecanthus often lays its eggs in canes of the grapes causing a characteristic scarring of the canes. Its injuries, however, are not serious since the nymphs do not feed on the vines.

\section{OTHER INSECTS INJURIOUS TO THE GRAPE}

Grape-leaf skeletonizer (Harrisina americana). Eight-spotted forester (Alypia octomaculata).

Grape plume-moth (O.rypitus periscelidactylus). Grape-cane borer (Amphicerus bicandatus).

(Schistocerus hamatus).

Grape-cane gall-maker (Ampeloglypter sesostris).

Cottony maple scale (Pulvinaria vitis).

Grape scale (Aspidiotus wve).

Apricot scale (Eulecanium armeniacum).

Grape curculio (Craponius incqualis).

${ }^{10}$ Parrott and Fulton-N. Y. State Expt. Stat., Bull. 388. 


\section{CURRAN'T PESTS}

TIIE mMPORTED CURRANT WORM ${ }^{11}$ (Pteroms ribesii)

Order-Hymenoptera. Manual, p. 6rз

An imported insect first found in New York about Rochester in 1857 ; it is a saw-fly with a reddish body about one-third of an inch long and four transparent wings. The adults appear soon after the leares put out and lay their egos along the veins of the undersides of the leares; ther hatch in a week or ten days; the larve have ro pairs of legs and eat voracionsly, often defoliating the bushes; when full-grown they are three-quarters of an inch long and burrow into the ground or hide beneath rubbish on the surface and spin cocoons within which they change to puper in July the adults appear and deposit their eggs for a second generation which is often more abundant than the first; the larva of this second generation remain in the ground all winter; possibly a partial third generation.

Control-Spray when larva are first seen with arsenate of lead, 3 pounds to 50 gallons of water; when berries begin to ripen use fresh white hellebore.

\section{THE CURRANT-STEM GIRDLER ${ }^{12}$ (Jamis integer)}

Order-Hymenoptera

An American insect that is widely distributed in New York State; in May, it girdles the new growth of the branches and the tips wilt and fall over; the adult insect is a saw-fly with a shining black body and transparent wings.

The winter is passed as a larva in burrows insicle the currant stems; in April it changes to a

11 Riley-Ninth Mo. Rept., p. 7.

12 Slingerland-Cornell Univ. Expt. Stat., Bu1l. 126. 
purla and in the last part of . Tay the adults appear: the female makes a hole in the tender branch with her ovipositor and then deposits her egs; she then girdles the branch about one inch above the egg; this she does in an interesting way with her ovipositor; the end of the stem wilts and falls over; the larva burrows down the stem going 6 or 8 inches by fall; it then spins a cocoon at the lower end and passes the winter.

Control-As soon as the wilted tips of the canes are seen in the spring they should be cut off 4 or 5 inches below the girdled place and burned. This will destroy all of the eggs.

\section{THE CURRANT MIOTII-BORER ${ }^{13}$ (Scsia tipuliformis) Order-Lepidoptera}

This is a beatiful clear-winged moth like the peach-tree borer; it is another imported pest and is said to be, in some localities, a serious one.

The eggs are laid on the stems in the axils of the leaves; the young larva bores into the stem and gradually tunnels out a burrow down the center as it grows; the larva become half grown by fall and pass the winter in their burrows; in spring they complete their growth and pupate; the moths appear in June. Affected stems produce small yellowish leaves and are soon broken off by the wind.

CONTROL-Infested stems should be cut off below the lowest part of the tunnel and burned.

\section{TIIE CURRANT APIIID ${ }^{14}$ (Mỹus ribis) \\ Order-Hemiptera}

The small black egos of the aphid are found on the stalks in winter and hatch just as the folliage

13 Lugger-Minn. Expt. Stat., Bu11. 43, p. I84.

14 Lowe-N. Y. State Expt. Stat., Bull. I39. 
appears: the aplids multiply and cause the foliage to curl and pucker; in the third generation winged females migrate to motherwort (Leomms) and hedgenettle (Stachy's) but some of the aphids may remain on the currants: in late October the winged migrants return to the currants and produce males and ego-laying females, the latter depositing the eggs.

Control-Spray before leaves are badly curled with nicotine sulphate, I pint to Ioo gallons of water with + pounds of soap added; spray the undersides of the leaves.

The four-Lined LeAf-BUg ${ }^{15}$ (Pocilocapsus lineatuts)

Order-Hemiptera

This is a common bug with many food plants but is often very injurious to the young foliage of currant and gooseberry; attacked leaves turn brown, curl up and become brittle.

The egos are deposited in slits cut lengthwise in the stems of the plants; they pass the winter in these situations and hatch early in the spring; the nvmphs have shining vermilion red bodies; they molt five times and become full-grown in $I 7$ to 20 days; the nymphs feed on the tenderest young foliage, causing brownish depressed spots to appear on the leaves; the adult bugs appear about the middle of June; lay their eggs, are active for about a month and then disappear.

Control--Spray the nymphs with nicotine sulphate, three-fourths pint to roo gallons of water; cut ofi tips of stems containing eggs and burn them.

${ }_{15}$ Slingerland-Cornell Univ, Expt. Stat., Bull. 58. 


\section{O'THER INSECTS INJURIOUS 'TO TIIE CURRANT}

Green currant worm (Gymnonychus appendiculatus).

Pepper-and-salt currant moth (Ll'cia cognataria).

Yellow currant fruit-fly (Epochra canadensis).

Dark currant fruit-fly (Rhagoletis ribicola).

San José scale (Aspidiotus permiciosus).

Walnut scale (Aspidiotus juglans-regia).

\section{STRAWBERRY PESTS}

\section{White GRUBS ${ }^{16}$ (Phyllophaga sp.) \\ Order-Coleoptera}

White grubs are the larvæ of May beetles or "June bugs"; there are at least eight species of these that are injurious; these insects have a prolonged life cycle, two to three years and may be longer in some cases; white grubs are liable to accumulate in old pastures and meadows and when these are broken and other crops put on the sod there is liable to be much injury; the grubs eat off roots of strawberry plants.

The eggs are laid in balls of earth in the ground where they hatch and the grubs live there until the stimmer of the second year when they change to pupæ in the soil; the pupre change to beetles in late summer but the beetles remain in their earthen cells until the following spring.

Control-Do not follow sod land with strawberries: put some other crop between; in gardens and small plantings dig grubs out by hand.

10 Forbes-Illinois Expt. Stat., Bull. I I6.

Davis-U. S. Dept. Agr., Far's' Bull. 940. 
TIIE STRAWBERry WeEvil ${ }^{17}$ (Anthonom signatus)

Order-Coleoptera

This is a small beetle about one-tenth of an inch long with a rather long proboscis; it is usually more injurious farther south and in the southeastern part of New York State.

The weevils emerge from their winter quarters early and the females deposit their egos within the buds of strawberries: the beetle then cuts off the flower-stem and the bud soon falls to the ground; the grub lives inside of the bud on the pollen and changes to a pupa from which the beetle emerges later: evidently but one brood a year.

Control-If possible plant mostly pistillate varicties with just enough staminate varieties to crossfertilize them; plant early-blooming staminate varieties as trap crops; cover beds with muslin; place beds in open ficlds away from fences, hedgerows, etc.; practice clean culture; dust plants with a mixture of sulphur 5 parts, and powdered arsenate of lead I part; begin dusting as soon as weevils are seen and make two applications one week apart.

The strawberry LeAF-Roller ${ }^{18}$ (Ancylis comp$\tan a)$

\section{Order-Lepidoptera}

Moths appear in early May in New Jersey; lay pale green eggs mostly on the undersides of leaves; these hatch in about one week; the young larva feeds a day or two on upper side of the leaf but soon folds the halves of the leaf together, tying it securely with silk and lives within fully protected from insecticides: becomes full-grown in about one

17 Chittenden-U. S. But. Ent., Circ. 21.

Headlee-N. J. Expt. Stat., Bull. 324.

18 Webster-Iowa Expt. Stat, Bull. I79. 
month and is then about $/ / 2$ inch long, yellowish to greenish-brown and head shining brown; transforms to pupa in folded leaf; in New Jersey 3 broods a year but first brood causes most injury.

Control-Make a thorough application of arsenate of lead, 5 pounds to IOO gallons of water, within a week after the first moths appear and before leaves are folded; burn over fields after crop is harvested; plow up old abandoned beds.

\section{O'THER INSECTS INJURIOUS TO THE STRAWBERRY}

Strawberry root-worm (Typophorus canellus).

Strawberry root-louse (Aplis forbesi).

Strawberry crown-moth (Sesia rutilans).

Green strawberry slug (Empria fragarice).

Obsolete banded strawberry leaf-roller (Archips obsoletana).

Strawberry root-weevil (Otiorlunnchus ovatus).

Strawberry crown-borer (Tyloderma fragaric).

\section{RASPBERTY AND BLACKBERRY PESTS}

THE RASPBERRY CANE-BORER ${ }^{19}$ (Oberea bimaculata)

Order-Coleoptera

The adult beetle is about one-half an inch in length witl a slender cylindrical body and long antenna: the prothorax is yellow, generally with two or three black spots.

The beetles appear in June and deposit their egos in the tender growth of the canes; the female then cuts two rings around the cane, one above and one below the eag; this causes the tips of the canes to wilt and fall over; the egs hatches and the young larva begins to bore downward in the center of the ${ }^{19}$ Comstock and Slingerland-Cornell Univ. Expt. Stat., Bull. 23. 
stem; it passes the first winter in its burrow not far from the egg and by the second fall reaches the root where it passes the winter, changes to a pupa in the spring and the beetle emerges in June.

Control-Cut off the wilted tips of the canes some distance below the egg as they appear in June.

\section{THE RASPBERRY SAW-FLY ${ }^{20}$ (Monophadmus rubi) Order-Hymenoptera}

A saw-fly, the larvæ of which are at times quite injurious to raspberries; it may feed also upon the blackberry and dewberry; the leaves are completely deroured, the new canes may be injured and the buds and young fruit sometimes suffer.

The adults appear the first half of May and deposit their eggs within the tissues of the leaves from the undersides; in a week to ten days they hatch; the full-grown larva is green in color with the body covered with spine-bearing tubercles; after feeding on leaves until nothing but veins are left the larvæ go into the ground two or three inches below the surface and make cocoons in which they spend the winter, changing to pupre in the spring; there is only one brood annually.

Control-The larvæ may be brushed from the plants to the ground where they will die; the plants may be sprayed with arsenate of lead, $2 \mathrm{I} / 2$ pounds to 50 gallons of water as soon as the larva are seen.

\section{THE STRIPED TREE-CRICKET ${ }^{21}$ (Oecanthus nigri- cornis ) \\ Order-Orthoptera}

This insect lays its eggs in the canes in the fall where they remain all winter; the eggs are laid in

${ }^{20}$ Lowe-N. Y. State Expt. Stat., Bull. I50.

21 Parrott and Fulton-N. Y. State Expt. Stat., Bull. 388. 
rows and cause long jagged wounds in the canes; the nymphs and adults live largely on plant-lice and other insects and must be regarded as beneficial; the wounds made by depositing the eggs injure the canes.

ConTROL-If abundant, affected canes should be cut out in the fall and winter.

TIIE RED-NECKED CANE-BORER ${ }^{22}$ (Ayrilus muficollis)

\section{Order-Coleoptera}

The stems of rasploerries sometimes bear irregular swellings or galls two or more inches in length and gradually tapering toward either end; caused by a beetle about one-third inch in length with reddish "neck" or thorax and black head; deposits egg in June in bark near base of leaf on new growth; young larva bores upward in sapwood passing around stem in a spiral manner thus girdling cane; it is a flat yellowish-white grub about $3 / 4$ inch in length; completes growth in spring and changes to pupa in cell in pith.

Control-Cut and burn infested canes during fall and winter; destroy wild berry bushes in which the beetles may breed.

\section{THE RASPBERry CANE-MAgGot ${ }^{23}$ (Phorbia rubi- vora) \\ Order-Diptera}

This is a small fly that attacks the new shoots of the raspberry in the spring; the attacked shoots wilt and droop; the tip shrinks, turns dark blue and dies.

As soon as the new shoots appear in the spring the fly deposits its eggs in the axils of the tip leaves: the white maggot burrows to the pith of the stem

22 Smith-N. J. Expt. Stat., Special Bull. N.

23 Slingerland-Cornell Univ. Expt. Stat., Bull. I26. 
and then begins to tumnel its way downward inside of the stem; after working downward a few inches it girdles the young shoot just beneath the bark which causes the tip to wilt; the maggot then tunnels farther downward until it reaches the surface of the ground; here it finally changes to a pupa in Jume and July; the pupa remains there until the following spring when the fly emerges; one brood a year.

Control-As soon as the drooping canes are seen in the spring they should be cut off several inches below the girdle and burned.

\section{TIIE RASPBERRY ROOT-BORER ${ }^{24}$ (Bembecia margi- nata) \\ Order-Lepidoptera}

The adult moths are clear-winged and closely related to the peach-tree borer; the borer or larva is yellowish-white and I to $\mathrm{I} / 2$ inches long; they attack the stems and roots of raspberries and blackberries, causing the plants to die.

The moths appear in August and September and lay their browish-red eass on the lower side of the leaves: the larve crawl down the stems and burrow beneath the bark; they may hibernate at once or if early they will feed and grow some before winter; the next summer they bore into the stems and roots sometimes girdling the stem at the crown and attacking new shoots; during the next summer the larve become full-grown and pupate, the moths appearing in August and September.

(oNTRoL-The only way of controlling this pest is to pull 11p infested plants and burn them.

24 Smith-N. J. Expt. Stat., Bull. N, p. 9.

Lawrence-Washington Expt. Stat., Bull. 63. 
O'THER INSEC'TS INJURIOUS TO 'THE RASPBERRY

Raspberry horntail (Hartigia abdominalis). Rose scale (Aulacaspis rosc).

American raspberry beetle (Byturus unicolor). Blackberry leaf-miner (Metallus rubi). Red spider (Tetranychus telarius). 


\section{INSECTS INJURIOUS TO VEGETABLES}

\section{WHITE PO'TATO}

The Colorado potato Beetle ${ }^{1}$ (I.cptinotarsa iolineata)

Order-Coleoptera. Manual, p. 576

Originally on a wild plant (Solanum) of the potato family in Colorado; gradually spread eastward to Nebraska I859, crossing the Mississippi River in I864 and reaching New York I872; moved at rate of $8 \&$ miles annually and reached the Atlantic in I874; in I 877 it reached England but was exterminated.

The beetles winter over, usually deep in the ground, occasionally under rubbish; female lays her orange-red eges in patches on the undersides of the leaves: she is capable of laying 500 to 2000 ; these hatch in 5 to 7 days: the grubs eat ravenously and mature in 2 or 3 weeks and then enter ground where they form cells and pupate; the pupal stage lasts io days to two weeks; there are two generations here, the adults of the seeond generation hibernating. The work of this beetle seems to affect quality of tubers.

ControL-Spray with paris green, I pound in $5^{\circ}$ gallons of Bordeaux mixture or arsenite of zinc, $\mathrm{I} / 2$ pounds to 50 gallons or arsenate of lead paste 4 pounds.

The POTATo FLEA-BEETLE ${ }^{2}$ (Epitrix cucumeris)

Order-Coleoptera

The potato flea-beetle is a small beetle with en-

${ }^{1}$ Chittenden-U. S. Bu. Ent., Circ. 87.

2 Johannsen-Maine Expt. Stat., Bull. 2 I I. 
larged muscular femora on the hind legs with which it jumps like fleas hence the name.

The beetles hibernate in hedgerows, along fences, etc., and appear early in the spring; they bite holes in the epidermis of leaves and eat out green tissue; later in the season they cause much injury by their persistent feeding; the engs are deposited on and in the soil around the base of the plant and the small larva feed on the underground stems and tubers; they bore straight into the tubers and cause "slivers" in the potatoes; pimple-like spots often occur over the outside of the potato where these larva are situated and cause "pimply" potatoes.

Control-Thorough spraying with Bordeaux mixture to keep the plants covered is the only satisfactory method of control. Arsenate of lead may be added or paris green for the Colorado potato beetle.

\section{Blister-BEETLE ${ }^{3}$ (Epicauta vittata) \\ Order-Coleoptera. Manual, p. 586}

This species is known as the striped blister-beetle; it is a large, slender beetle with soft, flexible elytra; these beetles pass through complicated changes in their life history; the eggs are laid in the earth and the young grulus feed upon the eggs of grasshoppers; the beetles often appear in great swarms over limited areas and are hard to control and quite destructive.

Control-Hand-pick into pans of kerosene, spray with strong poison mixture 3 pounds of arsenate of lead to 50 gallons of water.

TIIE ротато APHID ${ }^{4}$ (Macrosiphum solanifolii)

Order-Hemiptera

This aphid is widely distributed from Maine to

${ }^{3}$ Gibson-42nd Ann. Rpt. Ent. Soc. Ont.

4 Houser and Guyton-Ohio. Expt. Stat., Bull. 3 I7. 
California and during the past few years has been very destructive; it varies in color from pink to green; the black winter eggs are deposited on the rose and other plants; in the spring they hatch and the aphids infest potatoes most seriously in July and August; a generation developed about every two weeks; the potatoes wilt and finally die when badly infested; in September the aphids desert the potatoes and colonize on various weeds and particularly on the rose where the winter eggs are again laid.

Control-Clean culture with the destruction of all host plants so far as possible; spray infested plants with nicotine sulphate, $3 / 4$ of a pint to IOO gallons of water with 5 pounds of soap added.

TIIE POTATO STALK-BORER (Trichobaris trinotata) Order-Coleoptera

This pest of the potato is more injurious in the Vest apparently than here although it is often injurious in New Jersey and may become so in New York at any time.

\section{O'THER INSECTS INJURIOUS TO THE POTATO}

Egg plant flea-beetle (Epitrix fuscula).

Tobacco flea-beetle (Epitrix parvula).

Potato tuber worm (Phthorimaa operculella).

Potato-scab gnat (Pnyxia scabici).

\section{SWEET POTATO}

The sweet potato FleA-BEetle ${ }^{\overline{5}}$ (Chatocnema confinis)

Order-Coleoptera

A small bronze or brassy-brown shining beetle about one-sixteenth inch in length; hibernates over ${ }^{5}$ Smith-N. J. Expt: Stat., Rept. for 1908, p. 342. 
winter in rubbish appearing early in May in N. T.; lay their eggs at the bases of bindweed and the larva live upon the roots of these plants; adult beetles injure potato vines by eating the leaves.

(ONTROL-Dip leaves and stems of plants before setting in solution of arsenate of lead, I pound in Io gallons of water; delay setting of plants as long as possible.

The STRIPED SWEet Potato BeEtle ${ }^{6}$ (Cassida bivittata)

Order-Coleoptera

Most abundant and injurious of all the "Goldbugs"; less than $1 / 4$ inch in length and of a dull brownish-yellow color with a faint golden lustre; there are two black stripes on wing-covers; the egos laid singly on moler sides of leaves and each covered with a little black excrement; larva is dirty white and hears spines along sides of body: there are two lone spines, the anal fork, at end of abdomen; these carry the cast skins over the back; pupar brown and retains the larval skins.

Control-Dip plants as for flea-beetle and, in addition, spray in the field.

Tine sweEt POTATo WeEvil ${ }^{7}$ (Cylas formicarius) Order-Coleoptera

This weevil is an imported species found in this country in eastern Texas, southern T,ouisiana, \Tississippi, Alabama, Florida, and in part of Georgia: it passes winter as egg. larva, pupa, and adult; the weevils which are ant-like in appearance and about $1 / 4$ of an inch long are bluc-black with a red thorax and long proboscis; they lay their eges in cavities in the stems or tubers of sweet potato plants where

6 Smith-N. J. Expt. Stat., Bull. 229.

7 Chittenden-U. S. Dept. Agr., Far's' Bull. I020. 
they hatch and the larve tumnel through the tubers ruining them: the life cycle is about 5 weeks in hot weather and there are several generations each seaso11.

Control-Do not use slips or potatoes from weevil-infested localities; rotate crops and do not plant potatoes more than one year on same soil; burn or feed all infested tubers when crop is harvested; clean up all vines, culls, and rubbish in the fields; destroy volunteer sweet potato plants and morning-glory plants; spray potato plants with arsenate of lead, 5 pounds to roo gallons of water as soon as weevils appear.

\section{OTHER INSEC"TS INJURIOUS TO SWEET PO'TA'TOES}

Golden tortoise beetle (Coptocycla bicolor).

Black-legged tortoise beetle (Cassida nigripes).

Sweet potato plume-moth (Pterophorus monodactylus).

Cutworms (Several species).

\section{CABBAGE PES'TS}

The CABbage root-Maggot ${ }^{8}$ (Phorbia brassice)

() rder-Diptera

This pest is a small fly imported from Europe; it attacks cabloace, radishes, cauliflower, and other cruciferous plants; it also attacks cabbage plants in seed beds and causes much injury.

The flies appear early in the spring, first two weeks of May, and deposit their eggs in crevices in the soil close to the stem of the plant; they hatch in a week or ten days and the young maggots immediately burrow along the surfaces of the young

8 Slingerland-Cornell Univ. Expt. Stat., Bull. 78.

Schoene-N. Y. State Expt. Stat., Bulls. 301, 334, 4I9. 
roots and later into the main roots; the maggots complete their growth in 3 to 4 weeks and pupate in the soil near the cabbage plants; the pupal stage lasts from 12 to is clays and they pass the winter as pupe: probably three broods and in some seasons a partial fourth brood.

Control-For seed plants in beds, screen the beds with muslin; for plants in the field, destroy all cabbage, radish, and turnip stumps, leaves and refuse; plow in fall to destroy puparia; use tarred papers on plants in field; use carbolic acid solution and screens of muslin for radishes in garden; hellebore, I ounce to 2 gallons of water seems to control the fly on radishes.

\section{Cutworms on CABBAgES $^{9}$ (Various species)}

\section{Order-Lepidoptera}

There are many kinds of cutworms all larva of noctuid moths; these larve attack rarious kinds of plants and cause a great amount of injury; they remain in the ground mostly during the day and work mainly at night.

The spotted cutworm moths are flying from late May to October; they deposit their ribbed, hemispherical eggs singly or in clusters on the leaves of plants; the eggs hatch and each cutworm, which is ashy gray to brownish in color with two rows of black spots on the back, becomes $\mathrm{I} / 2$ inches long and feeds upon cabbage, tomato, turnip, onion, and other plants; when it becomes grown it transforms to a pupa in the ground; there are probably two generations annually and the partly grown caterpillars pass the winter completing their growth in the spring; at this time they are roracious and cause much injury.

Control-Do not follow sod with crops the cut${ }^{9}$ Gibson-Canad. Dept. Agr., Ent. Br., Bull. Io, p. 23. 
worms attack; plow land in August and allow it to lie fallow until the following spring; use poison baits of bran, arsenic, paris green, and molasses; hand-pick, etc.

The IMPorted CABbage-Worm ${ }^{10}$ (Pontia rape) Order-Lepidoptera

This is the common white cabbage butterfly present all over the United States; it was imported from Europe and first noted in Canada about I860 and in New York about I868; it feeds on nearly every cruciferous plant.

The butterflies appear in early spring and lay their eggs on the cabloage leaves; the eggs hatch in 4 to 8 days and the green velvety larva complete their growth in ten days to two weeks and change to chrysalids: this stage occupies one to two weeks in summer; the pupæ of the last brood in the fall remain over winter as such; there are three or four broods here. The insect has many parasites and diseases that aid in holding it in check.

Control-Spray the plants with a poison mixture before heading is far advanced; 5 pounds of paste arsenate of lead, 5 pounds whale-oil soap and IOO gallons of water have given good results; when plants are well headed one may use hellebore.

\section{The CABbage APHid ${ }^{11}$ (Aphis brassice)}

\section{Order-Hemiptera}

This is a plant-louse imported from Europe. It is covered with a whitish powdery secretion; it injures cabbages, cauliflower, turnips, etc.

In autumn the males and egg-laying females appear and the latter deposit their dark brown egrs in great numbers on the cabbage leaves; in the early

${ }_{10}$ Chittenden-U. S. Bu. Ent., Circ. 60.

11 Herrick and Hungate-Cornell Univ. Expt. Stat, Bull. 300. 
spring these hatch into the stem-mothers that live on the tender sprouts from the cabbage stumps; there is generation after generation of the winged and wingless aphids during the season until the sexes are produced again in the fall; this aphid has many parasitic and predaceous enemies.

Control-Destroy cablage stumps and all refuse in the fall; spray plants with whale-oil soap or nicotine sulphate, three-fourths of a pint to IOO gallons of water with 4 pounds of soap added.

The cabBage looper (Autographa brassica)

\section{Order-Lepidoptera}

A very injurious species on Long Island; it lacks some of the abdominal legs and therefore loops like a Geometrid; the white ribbed ege is depositer on the leaves; the larva at first is dark green with longitudinal white lines on sides of body; later it becomes pale green and lines become fainter; the pupa is in a thin white cocoon in fold of leaf on underside; apparently 3-brooded on Long Island: often injurious in greenhouses.

Control-Same treatment as for other cabloage caterpillars but the looper is harder to hold in check; cleaning up the fields in the fall is important in order to destroy the pupa that pass the winter among the refuse.

The harleguin CABbage BUG (Murgantia histrionica)

\section{Order-Hemiptera}

A very destructive Southern cabbage pest which has gained a foothold on Tong Island and is working northward in (Ohio: has been found as far north as Elmira, N. Y.; it lays its barrel-shaped eggs on leaves; they hatch in a few days and the nymphs complete their growth in mid-summer in probably 
about one month; propably two generations in a season in the north.

Control-Practice clean cultivation; plant early crop of mustard or radish as a trap crop and destroy the old bugs as they gather on this in the spring by spraying with pure kerosene and then by burning.

\section{OTHER INSECTS INIURIOU'S TO CABBAGE}

Imported cabbage web-worm (Hcllula undalis).

Diamond-back moth (Plutella maculipennis).

Cross-striped cabbage worm (Evergestis rimosalis).

Southern cabbage butterfly (Pontia protodice).

Flea-beetles (Various species).

Cabbage curculio (Centorhynchus rapce).

\section{ASPARAGUS PEST'S}

The Asparagus BeEtle ${ }^{12}$ (Crioceris asparagi)

\section{Order-Coleoptera}

For two hundred years asparagus had no pests; now there are two beetles that work on it, both being imported from Europe; the one here was first found in Queens County, New York, in I862, but had probably been introduced about I 856 .

The beetles hibernate under rubbish and appear in May; they lay their eggs on the stems of the asparagus where they hatch into soft grubs; these eat the plants and in ten days to two weeks attain their growth and go into the ground to pupate; in 5 to $S$ days the adult beetles appear, the whole life cycle occupying 3 to 7 weeks; 2 or 3 broods a season here.

Control-Hand-pick in small beds; cut down 12 Chittenden-U. S. Bu. Ent., Circ. I02. 
and clestroy all volunteer plants in spring to force beetle to lav eges on new shoots which are cut often; proison plants after cutting with arsenate of lead $2^{\mathrm{I}}{ }_{2}^{2}$ pounds, and soap + pounds, to 5o gallons of water; clean up rubbish.

The I2-SPOTted ASPARAGUS BeETLE ${ }^{13}$ (Crioceris duodecimpunctata)

Order-Coleoptera

This was not found until I $8 S_{\text {I }}$ and then near Baltimore; it is a less common and less injurious species than the former one but lives exclusively on asparagus; the adult beetles cause the injury.

The beetle is reddish-orange and has six black dots on each wing-corer; the elongate oral green eges are deposited on the plants in June; the es? hatches in 7 to $\mathrm{I} 2$ days and the grub at once bores into a berry and uswally enters about three berries before it becomes full-grown; when grown it pupates in the soil; there are two generations here in New Tork, the first brond of heetles appearing in late July and the second in early September.

Control-Same as for former species.

\section{The asparagus miner ${ }^{14}$ (Agromyar simpler)} Order-Diptera

The stalks of asparagus are often injured by the larva of a fly that mines beneath the epidermis; the mines are often so abundant that they have the effect of girdling the stalk.

The white eggs are stuck in the sides of the stalk just beneath the epidermis; they hatch into the small maggots that mine 11) and down beneath the epidermis: when the larve attain their growth they

${ }^{13}$ Chittenden-U. S. Bu. Ent., Bull. 66, Pt. I.

Fink-Cornell Univ. Expt. Stat., Bull. 33r.

${ }^{14}$ Fink-Cornell Univ. Expt. Stat., Bull. 33I. 
change to puparia; the puparia are attached to the stalk near the ground in slits in the epidermis; there are two generations, the winter being passed as puparia at the hases of the old stalks.

Control-Pull up infested stalks in spring and burn them; allow volunteer plants to grow as a trap crop which should be destroyed in late June.

\section{CUCUMBER PESTS}

The striped CuCuMBER BeETLE ${ }^{15}$ (Diabrotica vittata)

Order-Coleoptera

As soon as squashes, cucumbers, etc., appear above the ground in the spring they are attacked by a small yellow and black striped beetle; this beetle is distributed all over the United States east of the Rockies; it is native to this country; the beetles carry the organisms that cause bacterial wilt disease of cucurbits; the bacteria of the wilt disease pass the winter in bodies of hibernating beetles.

The beetles feed upon the leaves and blossoms and deposit their lemon-yellow eggs mostly in crevices of the soil near stem of plant; the long, slender, whitish larva attack the stems by burrowing into them. The larva pupate in ground and the beetles hibernate orer winter in sheltered places; there are two generations a season.

Control-Put in excess of seeds; protect plants with boxes or wire screen; hand-pick beetles in garden; dust plants with tobacco dust, ashes, or lime; spray with Bordeaux mixture and arsenate of lead or arsenate of lead alone; keep plants covered with this material; practice clean culture.

${ }^{15}$ Chittenden-U. S. Bu. Ent., Circ. 3I. 
The SQUASII BUG ${ }^{16}$ (Anasa tristis)

Order-Hemiptera

This is a large blackish-brown bug about three(quarters of an inch long that attacks cucurbits of all kinds; when it punctures a leaf to extract the juices it also injects a drop of liquid which has a poisonous effect on the leaf; moreover, it carries bacteria of the wilt disease from one plant to another.

The adult bugs appear in early spring and attack the plants; they lay their dark-brown eggs on the undersides of the leares in great numbers; these hatch in 8 to 13 days; the nymphs are green and black and abundant; they molt five times and complete their growth in about one month; the adult bugs hibernate under trash, there being but one generation.

Control-Trap old bugs in spring with chips or leaves placed under plants: hand-pick adults and eggs; kerosene cmulsion diluted with 7 to 9 parts water will kill nymphs but not adults.

\section{SQUASH AND MELON PESTS}

The sguasir bug-Already discussed under cucumber pests

The SQUASH-VINE BORER ${ }^{17}$ (Melittia satyriniformis)

Order-Lepidoptera

The parent moth is a beautiful clear-winged moth with a wing expanse of an inch to an inch and a half; it is distributed all over the eastern United States; it attacks squash, pumpkin, and occasionally melons, cucumbers, and gourds.

${ }_{10}$ Chittenden-U. S. Bu. Ent., Circ. 39.

17 Chittenden-U. S. Bu. Ent., Circ. 38. 
The moths appear in July and deposit their eggs (nn all parts of the plant, but chiefly along the stems; these hatch and the larva bores into the stem and then burrows along in the center of the stem causing it to rot and become severed from the vine; an affected stem wilts and dies; the larva attains a length of an inch and becomes full-grown in about four weeks; it leaves the stem and goes into the soil to pupate, the pupe remaining over until the following spring; one brood here.

Control-Insecticides or repellants of little or no avail; cut out the borers; plant the early varieties as a trap crop, or plant late varieties as late as possible; fertilize the soil well, and cover the plants at several joints where new roots can be formed; remove and burn vines as soon as crop has been secured to destroy eggs and larve; harrow soil in fall and plow deep in early spring to kill pupæ.

The melon plant-Louse ${ }^{18}$ (Aphis gossypii)

Passes winter in egg stage; breeds throughout summer like other aphids; is more injurious farther South.

Control-Spray thoroughly with nicotine sulphate being sure to hit the undersides of the leaves.

\section{OTHER INSECTS INJURIOUS TO CUCUMBERS AND MELONS}

Twelve-spotted cucumber beetle (Diabrotica I2punctata).

Squash ladybird (Epilachna borealis).

Pickle worm (Diaphania nitidalis).

Melon caterpillar (Diaphania hyalinata).

18 Chittenden-U. S. Dept. Agr., Far's' Bull. 9I4. 


\section{ONION PESTS}

Tite onion maggot ${ }^{19}$ (Hylemyia antiqua)

$$
\text { Order-Diptera }
$$

The insect passes the winter mostly as puparia 3 to 6 inches below the surface of the soil; the flies appear in May and deposit their white eggs on leaves of the plants, or on the stems near the soil, or in cracks of the soil; the egg hatches in 3 to 7 days and the maggots feed on the young onion bulb soon ruining it; they obtain their growth in If to Is days and then pupate in soil; the pupal stage lasts 2 to 3 weeks; there is evidently time for 2 or 3 generations in a season.

Control-Scallions should be planted late in September or early October; sometimes of advantage to make a small early planting in August as a trap crop; sow late, that is, in latter part of April or early May and force crops; rotate and get away from old infested fields: practice clean culture; use carbolic acid emulsion on onions in garden; use sweetened poison bait.

\section{The ONION THRIPS ${ }^{20}$ (Thrips tabaci) \\ Order-Thysanoptera}

This is a very small insect that causes a good deal of annual injury to onions in the United States; it is widely distributed all over the country and hard to control.

It passes the winter as adults and probably also as nymphs; the eggs are laid in tissues of the leaves just under the epidermis: they hatch in 3 to + days; larval stage 7 to 0 days: nymph stage + dars: whole life cycle I6 days; many overlapping broods; the ${ }^{19}$ Gibson and Treherne-Canad. Dept. Agr., Ent. Br., Bull. I2, p. 29.

${ }^{20}$ Quaintance-Florida Bull. 46. 
adults and the young ones scarify leaves of onions, cating off epidermis: leaves turn white, wilt and die; very injurious at times.

Control-Clean culture in fields and around the borders of fields; spray with the tobacco extracts, nicotine sulphate, $3 / 4$ pint to 100 gallons of water and 4 or 5 pounds of soap, preferably whale-oil soap; spray thoroughly and repeat two or three times 4 or 5 days apart; commence just as soon as thrips are seen.

\section{O'THER INSE(TS INJURIOUS TO ONIONS}

Black onion fly (Tritora flexa).

Cutworms (several species).

\section{TOMA'TO PES'IS}

\section{Cutworms (several species)}

Cutworms sometimes cut off the young plants when first set and destroy much more than they eat. A spoonful of the poison bait near each plant when first put out will aid in controlling these pests.

\section{FLEA BeEtLES}

The potato flea beetle often attacks tomatoes but max be repelled he thorough and frequent applications of Bordeaux mixture. It should be sprayed on the under sides of the leaves as much as possible.

\section{The nORTHERn tomato worm ${ }^{21}$ (Phlegethontius quinquemaculata) \\ Order-Lepidoptera}

There are two large green caterpillars very similar in appearance that attack tomatoes, one more

${ }^{21}$ Chittenden-Insects Injurious to Vegetables, p. 229. 
common in the North and the other more common in the South: the caterpillar hecomes about is inches long; the insect passes the winter in the ground as a pupa, the first moths appearing about June I; they deposit their exgs on the leaves and the caterpillars become grown in about 3 weeks when they go into the soil to pupate; the generations are sonewhat confused but there appears to be one in the North and two farther south each season.

Control-Hand pick the larve: spray with paste arsenate of lead, 5 pounds to roo gallons of water or dust with powdered arsenate of lead, $3 \frac{\mathrm{T} / 2}{2}$ to 5 pounds to the acre.

The tomato Fruit-WORM ${ }^{22}$ (Heliothis obsoleta) Order-Lepidoptera

This is the same as the corn ear-worm and bollworm of cotton. It is more abundant farther south. The larva eats into the tomatoes and often destroys large numbers of them.

Control-Plow land in fall or winter. Dust infested plants, especially the fruit, with powdered arsenate of lead.

\section{BEET AND SPINACH PESTS}

\section{BeEt LeAF-MINer ${ }^{23}$ (Pegomyia hyoscyami)} Order-Diptera

The parent insect is a fly about as large as a housefly; it passes the winter mostly as puparia in the soil; the flies appear late in April and in MIay and lay their eges on the undersides of the leares: the eggs hatch in from + to 6 days and the magrots burrow into the leaf where they make blotch-like mines; they become full-grown in 7 to $I+$ days and

22 Quaintance and Brues-U. S. Bu. Ent., Bull. 50.

23 Dickerson-N. J. Expt. Stat., Rept. for I9I I, p. 444. 
some pupate among or beneath decaying leaves, while others go into the soil; the pupal stage lasts about 3 weeks; there are probal,y 3 generations and perhaps a partial fourth.

Control-In gardens pick off and burn infested leaves; plow deep and harrow thoroughly as soon as crop is remored: with beets, use spinach as trap crop); destroy the wild food-plant (lambs-ruarters).

\section{THE SPINACH APHID ${ }^{24}$ (Myzus persice)}

\section{Order-Hemiptera}

The spinach aphid feeds on over roo plants; the adult is greenish-yellow to pinkish in color; in colder regions the aphid passes the winter as an egg on fruit trees while in warmer localities it may pass the winter as an adult on vegetables; in summer there are many gencrations on the spinach and great injury often results.

Control-No satisfactory method of control known.

\section{Spinacit Flea-BeEtle ${ }^{25}$ (Disonycha ranthomelcina) \\ Order-Coleoptera}

A shining black flea-beetle with red prothorax and about T't inch long; greatly injures sugar beets: beetles hibernate over winter; lay eggs at bases of plants; larva feed on underside of leaves and later, together with adults, eat holes in leaves; two generations at Washington, D. C.

Control-Dust plants or spray them with arsenate of lead; use Bordeaux mixture alone or with poison.

${ }^{24}$ Chittenden-Va. Truck Crop Expt. Stat., Bı11. 2.

25 Chittenden-U. S. Bu1. Ent., Bull. I9. 


\section{OTHER INSEC"TS INJURIOUS TO BEETS AND SPINACH}

Beets, especially sugar beets, when grown under field conditions, are subject to the attacks of a large number of insects, many of which (4O) are seriously injurious. The pests of garden beets are not, in the experience of the author, very numerous or very serious.

Beet aphis (Pemphigus bete).

Sugar-beet webworm (Loxostege sticticalis).

Beet army-worm (Laphygma exigua).

Striped beet caterpillar (Mamestra trifolii).

Flea beetles (several sps.).

Beet leafhopper (Eutettix tenellus).

Blister beetles (several sps.).

\section{BEAN AND PEA PESTS}

\section{Pea Weevil ${ }^{26}$ (Mylabrus pisorum) Order-Coleoptera}

Seed peas are often found with a hole in each due to the pea weevil; the weevil is about I-5 of an inch in length and marked with brown and white spots: passes winter as an adult and lays eges singly in spring on pods in field; on hatching larva bores through pod and into the pea; every pea in a pod may be infested; the larva matures inside of the pea and the life cycle lasts from 40 to 50 days, depending on season; one generation a year.

Control-Hold peas over one season, so that they will become freed of weevils; do not plant weevilly seed; plant late; fumigate seed with Cs..

${ }_{20}$ Chittenden-U. S. Dept. Agr., Yearbook 1898. 


\section{BEAN WEEVIL ${ }^{27}$ (Acanthoscelides obtectus)}

\section{Order-Coleoptera}

Adult beetle is about $\mathrm{I} / \mathrm{s}$ inch in length, with mottled wing covers; eggs inserted in the bean pod through holes made by female; life cycle from 2 I to So days; probably 5 or 6 generations annually; it also breeds in stored beans.

Control-No method of preventing injury in field: fumigate stored heans and plant clean seed.

\section{THE BEAN LEAF-BeETle ${ }^{28}$ (Cerotoma trifurcata)}

\section{Order-Coleoptera}

A small reddish black-marked beetle about I-5 inch long; adults hibernate and lay eggs in cracks of soil in spring near stem of plant; larvæ feed on roots and stems but adults eat holes in leaves; life cycle from 4 to 9 weeks; in South 2 or 3 generations, one in the North.

Control-Spray with arsenate of lead, 5 pounds to Ioo gallons of water.

\section{TIIE PEA APHID ${ }^{29}$ (Macrosiplum pisi) Order-Hemiptera}

Exceedingly injurious to peas some years in New Iork; life crcle similar to other aphids; passes winter in northern range on clover and retches; flies to peas in spring when these are available; several generations during season; goes back to clover in late season and lays eggs that pass winter; in south it passes winter as winged and wingless females.

Control-Do not plant peas near clover; no satisfactory remedy on peas sown broadcast; plant peas in rows and brush lice off and bury in soil by cultivation.

27 Chittenden-U. S. Yearbook, 1898.

28 Chittenden-U. S. Bu. Ent., Bull. 23.

29 Davis-U. S. Bu. Ent., Bull. 276. 


\section{O'TIER INSEC'TS INJIRIOUS TO PEAS}

Cow-pea weevil (Pachymerus chinensis).

Four-spotted bean-weevil (Pachymerus quadrimaculatus).

Bean ladybird (Epilachna corrupta).

Blister beetles (several sps.).

Bean aphid (Aphis rumicis).

Seed-corn maggot (Phorbia fusciceps).

Pea-moth (Semasia nigricana).

\section{CELERY PES'TS}

The celery Caterpillar ${ }^{30}$ (Papilio polynenes) Order-Lepidoptera

This caterpillar is green or yellowish and ringed with black and spotted with yellow; it becomes 2 inches long; when full-grown it changes to a chrysalis and later the parent insect, a large swallowtail butterfly, appears.

Tile CELERy LoOPER ${ }^{31}$ (Autographa falcigera)

Order-Lepidoptera

Where it occurs this insect is considered very destructive to celery; the larva is a looper and measures nearly 2 inches in length; the moth is purplish to velvety brown and has a conspicuous silvery comma-like mark on each wing.

Control-Hand pick and poison with arsenate of lead.

\section{The Carrot RUST-Fly ${ }^{32}$ (P sila rose $)$}

\section{Order-Diptera}

This insect sometimes attacks celery and causes the leaves to turn reddish and the roots to become

30 Davis-Mich. Expt. Stat., Bull. I02.

31 Chittenden-U. S. Bu. Ent., Bull. 33.

32 Chittenden-U. S. Bu. Ent., Bull. 33. 
blotched with rusty patches. The maggots also tunnel through roots of carrots. The parent insect is a small fly only about I -6 of an inch in length.

CONTROL-Late sowing and rotation of crops; celery should not follow carrots; clean cultivation and destruction of all remnants and refuse after crop is harvested.

\section{OTHER INSECTS INJURIOUS TO CELERY}

Celery leaf-tyer (Plilyctania fermgalis).

Wire worms (several species).

Tarnished plant-bug (Lygus pratensis).

\section{CARROT AND PARSNIP PESTS}

Celery caterpillar (Papilio polyrenes).

Parsnip leaf-miner (Acidia fratria).

Carrot beetle (Ligyrus gibbosus).

Parsnip webworm (Depressaria heracliana).

Carrot rust-fly (Psila rose). 


\section{INSECTS INJURIOUS TO HOPS}

\section{HOP-PLANT BORER ${ }^{1}$ (Gortyna immanis) \\ Order-Lepidoptera}

This is a native insect that is often serionsly injurious to hop vines in New York. It is distributed from Canada to Washington, D. C., on the south and westward to the Pacific Coast.

The light-brown moth appears from the middle of August to the last of September and deposits its pinkish ribbed eggs in the leaf sheaths and on the leaves and stems of grasses growing in and about the hop yards; the eggs rest over the winter and hatch during late April and through May; the larvae live for a time on the grasses but later go to the hops and some enter the heads where they cause "muffle" heads; others go to the stems and work downward to the roots where they eat out shallow grooves in the surfaces of the roots or burrow in the centers of the root; in from 9 to 12 weeks they mature and pupate in the soil, the moths appearing in August; there is one generation a year.

Control-Destroy all grass in and about the borders of the yards; pull out all extra vines before June I and remove them some distance from the yard; try paradichlorobenzene, using a few crystals in each hill and covering with dirt.

\section{The hop-PLANT LOUSE ${ }^{2}$ (Phorodon humuli)}

\section{Order-Hemiptera}

This insect is widely distributed here and in Eu1, 2 Hawley-Cornell Univ. Expt. Stat., Memoir I5. 
rope wherever the hop grows. It is often exceedingly destructive.

The egos are laid in the East in the fall on different varieties of plums; in the West the aphids are said to pass the winter on hop roots; the eggs hatch in the spring, and the winged forms of the third generation go from the plums to the hops, where they live until fall. They multiply rapidly and sometimes cover the leaves and stunt the vines. At picking time a winged generation flies back to the plums and gives birth to the true females which lay the eggs.

Control-Spray with nicotine sulphate, $3 / 4$ pint to Ioo gallons of water, with $\&$ pounds of whaleoil soap.

\section{Hop-vine SNOUT-MOTH ${ }^{3}$ (Hypena humuli) Order-Lepidoptera}

The larva of this moth are sometimes exceedingly destructive to the vines which they soon defoliate when abundant. It seems to have no other food plant than the hop and follows this plant in its distribution.

The larva are semi-loopers for they lack some of the prolegs; the pale green eggs are laid on the undersides of the leaves; the larva eat the leaves voraciously; the larva pupate in the ground, in crevices in the poles and in leaves; there are two generations a year, the last brood of moths hibernating in protected places.

Control-Spray vines with arsenate of lead, 5 pounds to roo gallons, or dust vines with powdered arsenate of lead, 4 pounds to the acre. It can be mixed with sulphur which is used for the mildew.

${ }^{3}$ Hawley-Cornell Univ. Expt. Stat., Memoir 15, p. Tgo. 
Hop merchants ${ }^{4}$ (Polygonia interrogationis) (Polygonia comma)

\section{Order-Lepidoptera}

The so-called hop merchants are simply the shining chrysalids of these two butterflies. The caterpillars of each are covered with branching spines and live upon the foliage of the plants. Both butterflies have two generations but the first generation of each is spent upon food plants other than the hop. The second generation of each is spent on the hop, the butterflies hibernating through the winter. Both butterflies show a dimorphism, the fall or winter forms differing from the summer forms.

Control-Use the powdered arsenate of lead, as for the snout-moth.

The hop RedBug ${ }^{5}$ (Paracalocoris hazuleyi)

Order-Hemiptera

The insect winters as eggs in the bark or attached to the wood of hop poles; the eggs hatch throughout most of June and the red nymphs deform and stunt the vines and produce holes in the leaves: the nymphs attain their growth in about thirty days the adults appearing in August; there is one gencration a year.

Control-Spray with nicotine sulphate, $3 / 4$ pint to Ioo gallons of water with 4 pounds of soap added.

\section{OTHER INSECTS INJURIOUS TO IIOPS}

Red Spider (Tetranychus telarins).

Hop flea-beetle (Psylliodes punctulata).

${ }^{4}$ Howard-U. S. Bu. Ent., Bull. 7.

5 Hawley-Cornell Univ. Expt. Staț., Memoir I5, p. I8z. 
Tufted looper (Ania limboda).

Leafhoppers (Typhlocyba sps.).

\section{TOBACCO PESTS}

\section{Tobacco FeA-Beetle ${ }^{6}$ (Epitrix paroula)}

\section{Order-Coleoptera}

A small yellowish-brown flea-beetle about I-20 of an inch long: it eats small cavities in undersides of leaves that finally become holes; the beetles appear in the spring and lay their eges on or near the soil; they hatch in a week; the larve feed on rootlets and attain growth in about 2 weeks: pupe are found in the soil; at least + broods in North Carolina; adult weevils pass the winter.

Control-Destroy all weeds of the potato family; in seed beds and in fields use arsenate of lead.

Southern tobacco IHORN-WORM ${ }^{7}$ (Phlegcthontius

\section{sevta) \\ Order-Lepidoptera}

Large green worms with horn on posterior end of body; they eat ravenously and do much injury: when full grown go into soil to pupate; pupa large and proboscis forms a handle-like organ; life cycle in stummer about six weeks in South; two bronds; last brood passes winter in ground as pupx; the adult moth has wing expanse of about 5 inches.

Control-Hand pick; dust tobacco with powdered arsenate of lead.

Tobacco splitworm. ${ }^{8}$ (Phthorimaa operculella) Order-Lepidoptera

Fggs laid on leaves of plant; larve mine between ${ }^{6}$ Metcalf and Underhill-N. C. Expt. Stat., Bull. 239.

7 Morgan-U. S. Bu. Ent., Circ. I23.

${ }^{8}$ Chittenden-U. S. Bu. Ent., Circ, 162. 
the surfaces of the leaves; two or more generations in a season; also works in tubers of potatoes.

Control-Clean cultivation; rotation of crops; probably arsenical sprays.

OTHER INSECTS INJURIOUS TO TOBACCO

Cut worms (several species).

False tobacco bud worm (Heliothis obsoleta).

Tobacco bud worm (Chloridea virescens).

Tobacco "suck-fly" (Dicyphus minimus).

Cigarette beetle (Lasioderma serricorne). 


\section{INSECTS INJURIOLS TO CEREMI, CROPS WHEA'T PESTS}

\section{THE HESSIAN FLY ${ }^{1}$ (Mayetiola destructor) \\ Order-Diptera}

Probably the most injurious pest on wheat in the United States; imported from Europe and first noticed on Long Island in I 550 ; attributed to the Hessian soldiers in the Revolutionary War. Passes winter as pupa or full-grown larva between blades and stalk of young winter wheat just above the roots; adults appear in spring (May) and lay eggs on upper surfaces of leares: maggots hatch and go to the bases of leaves above first and second joints; maggot stage 20 days or more; changes to a puparium and passes the summer as such in stubble; fall flies appear in August and first days of September: these lay eggs and produce puparia which pass the winter again; some flies may issue before winter.

Food PLANTs-Eggs often on grass but larvæ live only on wheat, barley and rye; so-called red wheat seems to be more exempt from injury than the white wheat (see Felt, U. S. Bu1l. 3I, p. 22); drought prolongs the flaxseed stage greatly.

Control-Burn stubble or plow under to destroy flaxseeds; destroy volunteer wheat; sow wheat late, not earlier than September 2oth to escape depositon of eggs by fall flies; sow strips of wheat early in August and then plow under or burn first week in September.

1 Webster-U. S. Bu. Ent., Circ. 70. 


\section{The wheAT MIDGE ${ }^{2}$ (Contarinia tritici)}

\section{Order-Diptera}

An old Emopean pest closely allied to the IIessian fly: the adult is bright orange colored and about one-third the size of a mosquito; the flies lay eggs in Jume hetween the chaff of wheat heads; eggs hatch in alout a week, and the reddish-yellow maggots extract the juices from the kernels causing the latter to become much shrunken and worthless either for seed or for flour; these "red-weevils" or maggots become full-grown in 3 or + weeks and some leave the heads, ustually during a rain storm; these go into the ground and remain in cocoons until spring; others remain in wheat heads and are carried into the thresher and come out in the screenings; they remain in the chaff in a dried-up condition until spring: now occurs in nearly all the states east of the Mississippi; shrivelled kernels will not grow good strong plants, nor make good flour, hence such had better be fed out; no varieties are exempt, but beardless varieties suffer more injury than the bearded.

Control-Burn or feed out screenings; after harvesting, deeply plow under the stubble; rotate the wheat to some distant field; early sown wheat may escape with less injury by the midge, but is more liable to the attack of the Hessian fly.

THE CHINCH-BUG ${ }^{3}$ (Blissus leucopterus)

\section{Order-Hemiptera}

Not often injurious in the East: has been injurious over small areas in New York several times; two broods of the insect a year; winters in the stools of grasses in the adult stage.

Control-IVestern methods of fighting the in-

2 Marlatt-U. S. Dept. Agr., Farmers' Bull. I3z.

3 Marlatt-U. S. Dept. Agr., Far's' Bull. I32. 
sect with barriers and fungus diseases ; consult bulletins and circulars from the Kansas and Illinois Experiment Stations.

\section{WIREWORMS ${ }^{4}$ (several species) Order-Coleoptera}

These pests are the larve or grubs of click-beetles of the family Elateridre; the grubs are yellowish, cylindrical, and hard like wire, hence the name wireworms; these wireworms live two and in most cases nearly three years in the soil and near the end of the third summer they change to pupe in cells in the soil and later the pupe transform to the adult beetles which remain in their cells until spring, thus taking three years to complete their life history; the beetles lay their eggs at the roots of grasses or in the soil.

Control-Difficult to control; conflicting evidence regarding coating of seeds; plowing and thorough cultivation in August and later for 2 or 3 years will kill the pupe and finally check the pests; salt will not kill wireworms unless it is applied in such large quantities that it completely unfits the soil for crowing crops, and even then is a doubtful killing agent.

\section{THE WHEAT STEM-MAGGOT ${ }^{5}$ (Meromyza americana)$$
\text { Order-Diptera }
$$

The winter is passed as a larva; the adult flies emerge in May and deposit their eggs on wheat plants; second brood of adults appears in July and deposits eggs on volunteer wheat and grasses; adults from these eggs emerge in late August to

${ }^{4}$ Comstock and Slingerland-Cornell L'niv. Expt. Stat., Bull. 33.

Hyslop-U. S. Bu. Ent., Bull. I56.

5 Marlatt-U. S. Dept. Agr., Far's' Bull. I32. 
Octoher, and deposit eggs on young fall wheat plants, where they hatch into larva and pass the winter; the larve do the injury to young plants in fall and spring.

Control-Sow late as for Hessian fly.

THE GREATER WHEAT STRAW-WORM ${ }^{6}$ (I sosoma

\section{grande)}

Order-Hymenoptera

This pest is mainly injurious west of the Mississippi, but is distributed east.

The adults always small and frefuently wingless, emerge in April from stubble and deposit eggs in stems of young plants in or just below the embryonic wheat head; the larva eats out the embryonic head of the wheat plants and usually causes a slight enlargement of the stem; adults appear from these, large and robust in June, and deposit eggs in stems just above the upper joints usually; by ()ctober the larva pupate and pass the winter in stubble.

Control-Burn stubble; rotate crops.

\section{The WHEAT JOINT-WORM ${ }^{7}$ (I sosoma tritici)}

\section{Order-Hymenoptera}

First serious outbreak in Virginia in ${ }_{1} 8_{4} 8-\mathrm{I} 8_{54}$, and reappeared in Indiana, Michigan, Ohio, Pennsylvania, Virginia, and Maryland in I0O4-Ioos.

Lives over winter either as a larva or a pupa in wheat straws; adults appear in April or May and lay eggs in stems of plants at the joints; larve form cells in stems and feed there until straw hardens and grain ripens; the larve deform the straws, galls being formed above the joints; grains remain small and shrivelled or none produced; many of the affected straws break and fall over.

6 TVebster and Reeves-U. S. Bu. Ent., Circ. Io6.

7 Webster-U. S. Bu. Ent., Circ. 66.

Houser-Ohio Expt. Stat., Bull. 226. 
Control-Strengthen fertility of soil to produce strong plants; burn stubble where not seeded or plow under deeply; rotate crops.

\section{THE ARMY WORM ${ }^{8}$ (Helioplita unipuncta) Order-Lepidoptera}

For years there have been outbreaks of this pest in various localities in the eastern United States. Outbreaks in New York State in IS6r, IS75. is So, IS90; the larva migrate in immense numbers from one field to another, destroying the vegetation in their path.

The eggs are deposited in unfolded grass leaves or into the sheath of the leaf where it clasps the stem; the larvæ attain their growth in about 30 days and go into the ground to pupate; the pupal stage lasts from I 2 days to 3 or + wecks depending on the season; the winter is passed as larva; there are evidently two broods, the July brood being the most abundant and injurious; in the south there are more generations.

Control-Usually fought by barriers in the same way as the chinch bug and by poison baits.

\section{GRASSHOPPERS ${ }^{9}$}

There are several destructive species of grasshoppers in the United States; perhaps the redlegged grasshopper (IIclanoplus fomur-rulrum), the differential grasshopper (Mclanoplus differentialis), the lesser migratory grasshopper (Mclanoplus atlanis), and the two-striped grasshopper (Mclanoplus birittatus) are the most generally distributed of any of the injurious species.

In general the eggs of grasshoppers are laid in

8 Knight-Cornell Univ. Expt. Stat., Bull. 376.

9 Herrick and Hadley-Cornell Univ. Expt. Stat., Bull. 378.

Walton-U. S. Dept. Agr., Far's' Bull. 747. 
the late summer or early fall in the ground; the eags remain here mutil the following April, May, and June, when they hatch into the young wingless grasshoppers; the young insects repuire 70 to 90 days to attain their growth; there is usually but one generation a year.

ConTrol-Destroy eggs by thoroughly disking or plowing the soil in which the eggs are deposited; catch the young grasshoppers in hopperdozers; poison them by scattering broadcast the Kansas poison bait.

\section{OTHER INSECTS INJURIOUS TO IVHEAT}

Spring grain-aphid (Toxoptera graminum).

Wheat sawfly borer (Ceplus pygmaus).

Wheat sawfly (Pachynematus extensicornis).

Wheat-louse (Nectarophora avenc).

Leather-jackets (Tipulida sps.).

\section{CORN PESTS}

\section{WireWorms (several species)}

These have been fully discussed under wheat pests. They are quite as injurious to corn as to wheat. In fact, they constitute one of the chief pests of corn in New York State.

\section{The Army worm (Heliophila mipuncta)}

The army worm is injurious to wheat, corn, oats, and many other grains. There are occasional outbreaks of this insect in New York, which are often very serious. The season of I9I + witnessed some serious injuries by this insect. It has been discussed under wheat pests. 


\section{Cutworms (several species)}

There are several species that injure corn as well as wheat. They are apt to be more abundant and severe on corn planted on sod. They have been discussed under wheat pests.

\section{White grubs (Phyllophaga sps.)}

These are injurious to many crops, notably strawberries, wheat, corn and oats. They were discussed under strawberry pests.

\section{Sod Webworms ${ }^{10}$ (Crambus sps.)}

Order-Lepidoptera

These are the larva of a family of small moths of the family Crambide; the larve are about one-half inch in length and pinkish-red or brownish; they work at first underground gnawing away the outer surface of the stem and roots; later, they burrow up the center of the stem; they also sometimes eat the leaves: usually the webworms will be found just below the surface each in a retreat formed by loosely webbing together a mass of dirt; within the mass is a silk-lined tube and within this a caterpillar; so far as known all of the species pass the winter as caterpillars not full grown; some have one generation and some two each year.

Control-Break land early in fall or as late as possible in spring to destroy larvæ.

\section{The CORN BILlbug ${ }^{11}$ (Sphonophorus callosus) Order-Coleoptera}

There are several species of snout-beetles known as "billbus" that injure corn by eating cavities in the stem close to the ground or just below the surface of the soil; the grubs also burrow inside of the

10 Forbes-23rd Rept. I11. State Ent., I905.

11 Satterthwaite-U. S. Dept. Agr., Far's' Bull. I003. 
stem near the base and in the tap root; in general the beetles are robust, reddish-brown, or black, or clay-colored, and vary from $1 / 2$ to $5 / s$ of an inch $0 r^{\circ}$ more in length; perhaps the "curlew bug" or "rice bug" is the best known.

The beetles hibernate and appear early in spring when they feed on grasses or corn; in May the beetle digs cavities in the stalks of young corn near or below the soil and lays her eggs in them; in older corn the eggs may be laid in the thick leaves; the ego hatches in about a week and the grub burrows in the tap root; in from + to 6 weeks the grub becomes mature and pupates in its burrow; the pupal stage lasts $\%$ to io days; there is but one generation a year; the small blue-grass billbug ( $S$. parz'ulus ) breeds in grasses, especially blue-grass and timothy; the clay-colored billbug ( $S$. equalis) breeds in coarse swamp grasses.

Control-Sodland suspected of infestation with billings should be plowed in the fall or planted to some crop other than corn; in the south early planted corn is least injured; rotation of crops is advantageous.

\section{THE CORN EAR-WORM ${ }^{12}$ (Heliothis obsoleta) Order-Lepidoptera}

The corn ear-worm, the cotton bollworm, and the tomato fruit-worm are all one and the same; the life history of this insect has been discussed under cotton pests; in the case of corn the moth deposits her white eggs on the corn silk; they hatch and the caterpillars enter the tip of the ear, where they gnaw and eat the kernels, sometimes burrowing down the whole length of the ear; they produce much brown excrement which lodges along their 12 Quaintance and Brues-U. S. Bu. Ent., Bull. 50. 
burrows; the injury is often severe, especially farther south.

Control-Dusting the ends of the ears with a mixture of powdered arsenate of lead, $3 / 4$ pound, and sulphur, $1 / 4$ pound, has given fair results.

The EUROPEAN CORN BORER ${ }^{13}$ (Pyrausta mulilalis) Order-Lepidoptera

This insect has lately been discovered in the United States and is now known to exist in Massachusetts, New Hampshire, Penmsylvania and New York.

The insect passes the winter as nearly full-grown caterpillars inside of cornstalks, cobs, weeds and grasses; during May the larve pupate in their burrows; this stage lasts from I4 to 20 days and the moths appear in MIay and June; they lay their eggs in batches on the undersides of the upper blades of the corn; the larvæ from these mature in about 4 weeks and on the average pupate in July; the moths from these appear the last of July or first of August and lay eggs which produce the caterpillars that pass the winter; this is the life history in eastern Nassachusetts, but in central New Jork there appears to be but one generation.

Control-Root up and burn the infested cornstalks some time during the winter.

\section{THE CORN ROOT-APHID ${ }^{14}$ (Aphis maidiradicis)}

\section{Order-Hemiptera}

This aphid is closely associated with the cornfield ant (Lasins niger, var. americanus), in fact, seems dependent on it for its existence; in the fall the exs-laying females deposit their esgs in the galleries of the ant's nests and the ants care for the

13 Vinal and Caffrey-Mass. Expt. Stat., Bull. 189.

${ }_{14}$ Davis-U! S. Dept. Agr., Far's' Bull. 89I. 
enges through the winter; during the latter part of March or first of April the eges hatch and the ants transfer the young lice to the roots of smartweed, crabgrass, or purslane along which the ants have previously made galleries; two or three generations of lice are produced here, but as soon as the young corn comes up the ants make tunnels along the roots of the corn plants and bring the lice over from the weeds; during the season there may he many generations of the lice; they suck out the juices of roots and starve the plants.

Control-Rotation of crops is of advantage, no crop other than corn heines attacked except cotton: dilute $1 / 4$ pound of oil of tansy with 2 quarts of alcohol and I quart of water and thoroughly mix this with Ioo pounds of bone meal; distribute it over an acre with a fertilizer attachment to the planter.

\section{THE CHINCH BUG (Blissus lencopterus)}

The pest often attacks corn as well as wheat and becomes very injurious where it is abundant. It has been discussed under wheat pests.

\section{OTHER INSEC'TS INJTRIOY'S TO CORN}

Stalk-borer (Papaipema nitela).

Seed-corn maggot (Phorbia fusiceps).

Northern corn root-worm (Diabrotica longicornis).

Fall armyworm (Laphygma frugiperda).

\section{CLOVER AND ALFALFA PESTS}

\section{Clover ROOT-BOrer ${ }^{15}$ (Hylastimus obscurus)}

Order-Coleoptera

A small, dark-brown beetle I-Io of an inch long

15 Folsom-Illinois Expt. Stat., Bu1l. I34.

Howard-U. S. Bu. Ent., Circ. 4. 
imported from Europe that works on second-year and older clover roots; eggs laid in May and June in cavities dug in the crown or in roots and larva bore galleries in the roots, causing plants to wilt and break off at crown; pupre form in cavities in roots and adults appear by October but remain in roots over winter, feeding when not dormant; some of the larvæe also pass the winter in the roots; attacks alfalfa, red clover, mammoth clover and alsike.

CONTROL-Plow an infested field immediately after hay gathered; never allow clover to stand more than two years if it becomes infested.

Clover leaf-Beetle ${ }^{16}$ (Hypera punctata)

\section{Order-Coleoptera}

A snout beetle which works on the leaves, mostly at night; the grubs also work in a similar manner; most of its injury is done in May and June; when full grown the grubs change to pupre in peculiar, yellowish lace-like cocoons of silk in the soil or at the bases of the plants; beetles usually hibernate but many die before spring; larva of all sizes pass the winter under débris among the plants on the ground: these complete their growth in spring and the beetles appear in June and July; they do not lay their eggs until September; there is in the North usually but one generation.

Control-A fungous disease usually kills the grulos in most localities; plow under the infested fields after second season, thus destroying the early stages of the insect.

Clover flower-Midge ${ }^{17}$ (Dasyncura

leguminicola)

Order-Diptera

This fly often prevents the formation of seed; 16, ${ }^{17}$ Folsom-Illinois Expt. Stat., Bull. I34. 
eggs are laid in green flower-heads and the mageots suck out the contents of ovary; when grown the maggots enter the ground and pupate; the insect passes the winter as a larva in the soil or in dead clover heads; there are two broods and a partial third; most damage to seed crop is done during August or first part of September; most injury occurs to second-year clover and keeps increasing as clover is allowed to stand.

Control-Cut first crop of clover as early as possible to allow seed to form early ahead of second generation of midges; pasturing the first crop does almost as well.

Clover seEd-CHALCID ${ }^{18}$ (Bruchophagus funcbris) Order-Hymenoptera

This small wasp-like insect is one of our worst clover pests; the tiny larvæ eat out the insides of the seeds leaving only a thin shell; the insects pass the winter mostly as larva in the seeds on the sround; the adults appear about May isth and thrust their eggs into the developing ovaries of the flowers of clover; second brood of flies appears in July and August; injury is greatest to the secondyear clover.

Control-Cut first crop early, as soon as the field comes into bloom; plow up clover after second crop, plow early in spring.

\section{Tiie AlFAlFA WeEvil ${ }^{19}$ (Phytonomus posticus)}

\section{Order-Coleoptera}

An European snout-weevil first found injuring alfalfa in Utah in I904; it is found in a small area in Ltah, southern Idaho and southwestern II yoning; the winter is passed as adults in the fields: in

18, 20, 21 Folsom-Illinois. Expt. Stat., Bull. I34.

19 Reeves, Miles, et a1.-U. S, Dept. Agr., Far's' Bull. 74I. 
early spring they lay eggs in the clover stems; these hatch and the larva mature in 29 to 58 days; each one spins a lace-like cocoon among leaves or rubbish on the ground; the pupal stage lasts 6 to I4 days and the weevils of the new generation begin to appear in June; these lay some eggs in the fall.

CONTROL-Spray fields as soon as the weevils begin feeding in April with arsenite of zinc, 4 pounds to Ioo gallons and put from 50 to Ioo gallons on an acre; cut first crop by middle of May; brush-drag field to kill weevils.

Clover seed-CATerpillar ${ }^{20}$ (Enarmonia interstinctana)

Order-Lepidoptera

The caterpillars of this moth eat out cavities in the heads of clover and often become very destructive; there are thrce broods a season; probably pass the winter as larva occasionally, usually as pupæ.

Control-Cut and store hay crops early in June; do not allow clover to run more than two years; pasture clover in fall of first year.

Clover hay-worm ${ }^{21}$ (Hypsopygia costalis) Order-Lepidoptera

This hay-worm works in stacked or stored clover, eating much of it and contaminating much more with webs of silk and particles of excrement, making the hay unfit for fodder.

Control-In a barn, old hay should be removed and burned if infested; a stack should be raised above the ground on old logs or rails; salt bottom of stack up two or three feet.

OTHER INSECTS INJURIOUS TO CLOVER AND ALFALFA

Clover leaf-midge (Dasyneura trifolii).

Clover stem-borer (Languria mozardi). 
Clover sitones (Sitones flarescens).

Clover-root mealy bug (Pscudococcus trifolii).

Alfalfa looper (. Aulougrapha gamma californica).

Alfalfa caterpillar (Eurymus curythome).

Clover-root curculio (Sitones hispidulus).

Alfalfa gall midge (Asphondylia miki).

Lesser clover-leaf weevil (Phytonomus nigrirostris).

\section{COTTON PESTS}

Mexican COTton BOLL-WeEvil ${ }^{22}$ (Anthonomus

\section{grandis) \\ Order-Coleoptera}

Introduced from Mexico about I892; a grayishblack snout beetle, about $\mathrm{I} / 8$ to $\mathrm{I}-3$ of an inch in length; punctures sfuares and bolls and deposits eggs in them; life cycle from I 5 to 20 days; several generations in a season and all stages passed in squares and bolls; passes winter as adults and causes millions of dollars loss each year.

Control-Plant cotton early; plant early varieties and hasten maturity by fertilization and cultivation; plant wide in rows; burn infested plants in fall to destroy all stages of weevil; rotate crops and diversify; poison with calcium arsenate.

\section{Cotton worm ${ }^{23}$ (Alabama argillacea)}

\section{Order-Lepidoptera}

The cotton moth lays its eggs on leaves of cotton; the eggs hatch in 3 to + days; young larva feeds for a time on the undersides of leaves but soon begins to devour leaves entirely; it molts five times and attains its growth in 2 or 3 weeks and then changes to a pupa in a flimsy cocoon in a leaf; life

22 Hunter-U. S. Dept. Agr., Far's' Bull. 344.

23 Hunter-U. S. Bu. Ent., Circ. I53. 
cycle about four weeks on the average; several generations during a season; passes winter as adults in tropical regions south of the United States; migrates northward in spring.

Control-Dusting cotton with powdered arsenate of lead best method; this insect is now held to be of value in controlling the boll weevil and therefore is not fought as it used to be.

\section{CotTon BOLLWOrm ${ }^{24}$ (Heliothis obsoleta)}

Order-Lepidoptera

One of the serious pests of cotton; moth deposits ribbed eggs on leaves of cotton; larva feeds for a short time on leaves but soon bores into a boll where it destroys the lint; life cycle about 30 days in summer; four generations a season; passes winter as pupa 3 to 6 inches below the surface of the soil; also attacks corn and tomatoes.

Control-Use trap crops of corn; plough land thoroughly during fall and winter; plant crop carly in spring; rotate and diversify crops.

THE PINK COTTON BOLLwORM ${ }^{25}$ (Pectinophora gossypiclla)

Order-Lepidoptera

The parent is a small grayish-brown moth which probably came from India or Africa and is now established in Brazil, Mexico, and Iawaii; first found in United States in IgI7 in Texas.

Eggs are laid singly or in groups on bolls and hatch in 4 to 12 days; the larve burrow in the bolls and become mature in 20 to 30 days; pupal stage passed inside of boll and lasts from io to 20 days : life cycle 35 to 50 days, and there are from 4 to 6 generations a year; winter is passed in larval stage.

${ }^{24}$ Quaintance and Brues-U. S. Bur. Ent., Bu11. 50.

25 Busck-U. S. Dept. Agr., Jr. Agr. Res,, Vol. IX, p. 343. 
Control-No adequate methods of control known; attempts are being made to exterminate in this country.

TIIE RED SPIDER ${ }^{26}$ (Tetranychus telarius)

\section{Order-Acarina}

The red spider has been reported on $I_{3} 3$ species of plants many of which are cultivated forms; it is a serious pest in greenhouses and one of the injurious pests of cotton.

The winter is passed in the south in the adult stage on several wild plants and especially on cultivated violets; the eggs, laid on the undersides of the leaves of cotton, hatch in about 4 days and the female mite becomes mature in about Io days; the first spring brood matures during March or early April in South Carolina and there is opportunity for from 12 to $\mathrm{I} 7$ broods.

Control-Destroy all weeds, especially pokeweed, about the fields and plow fields in fall if possible; destroy or spray cultivated violets: watch for infested cotton plants early and pull them up and destror them: finally spray cotton with potassium sulphide, I oz. to 2 gallons of water, or with lime-sulphur or flour paste, I pound flour to I gallon water made into a paste and then diluted at the rate of I part of paste to 9 parts of water.

\section{OTHER INSEC'TS INJURIOL'S TO CO'T'TON}

Cotton aphid (Aphis gossypii).

Cotton root-louse (Aphis maidiradicis).

Cotton stalk-borer (Ataxia crypta).

Cotton stainer (Dysdercus suturellus),

${ }_{26}$ McGregor-U, S. Dept. Agr., Far's' Bull, 83r. 


\section{INSECTS INJURTOUS TO STORED GR:II ${ }^{1}, 2$}

It is estimated that stored grain insects cause an annual loss in this country of at least \$200,000,000. They are more destructive in the southern United States although injury seems to be growing more common in northern latitudes. Most of the stored grain insects in this country have been introduced from foreign countries. It is said that over fifty species live habitually or occasionally in stored grains and grain products. Not more than a dozen of these are of primary importance. The more important ones are: The Angoumois grain moth (Sitotroga cercalclla), the granary weevil (Calandra granaria), the rice weevil (Calandra oryza), the saw-toothed grain beetle (Silvamus surinamensis), the Mediterranean flour moth (Ephestia kuchniclla), the Indian meal moth (Plodia intcrpunctella), the pea weevil (Mylabrus pisormm), and the bean weevil (Acanthoscelides obtectus).

Control-One of the best ways to keep seed corn, seed peas, wheat, beans, etc., is to store them in barrels or tight boxes; fill the boxes or barrels within 4 or 5 inches of the top and cover; if weevils or moths get in them pour carbon bisulphicle, at the rate of $\mathrm{x} / 2$ teacupful to a barrel of grain, into a tin dish and set this on top of the grain and cover the box or barrel with old blankets; leave covered 3 or 4 days; the liquid will evaporate and the gas

${ }^{1}$ Chittenden-U. S. Dept. Agr., Far's' Bull. 45.

2 Back and Duckett-U. S. Dept. Agr., Far's' Bull. 983. 
will settle down through the grain and hill the insects; do not go near the boxes with a light of any kind until the covers have been removed and the boxes thoroughly aired.

In general, where bins or granaries are actually air-tight or nearly so, from 3 to 5 pounds of carbon 1)isulphide to IOOO cubic feet of space should be sufficient. Under ordinary circumstances from I 5 to 20 pounds per IOOO cubic feet are necessary owing to the cracks and openings. ${ }^{3}$ Best results will be obtained when the temperature is above $75^{\circ} \mathrm{F}$.

Within the last few years heat ${ }^{4}$ has been used to exterminate stored grain insects, especially in flour mills. The radiation surface is increased until a temperature of $I I 8^{\circ}$ to $125^{\circ} \mathrm{F}$. can be maintained for several hours.

A very simple method of preventing injury to peas and beans is by the use of air-slaked lime." For small quantities use four parts of lime to one part of seeds; for quantities from a peck to three bushels use equal amounts of lime and seeds; for larger amounts use one part by weight of lime and two parts of seeds. The seeds and lime should be mixed somewhat when ready for storage.

\section{INSEC'TS INJURIOUS TO GREENHOUSE PLANTS}

The Greenhouse LeAf-Tier ${ }^{6}$ (Phlyctacnia

\section{ferrugalis) \\ Order-Lepidoptera}

The parent insect is a rusty-brown moth that lays its flat eges in groups of 2 to $\mathrm{I} 2$ on the undersides of the leares of greenhouse plants; they hatch in Io to 12 days; the caterpillars are pale greenish-white

3 Hinds-U. S. Dept. Agr., Far's' Bull. 799.

${ }^{4}$ Dean-Kan. Expt. Stat., Bull. 189.

5 Metcalf-Jr. Ec. Ent., Vol. X, p. 97. 
in color with a narow, dark-green stripe down the back and about if of an inch long when mature; they tie the leares together and feed on them, disfiguring the plants; the caterpillar becomes grown in from I 5 to 20 days and pupates between two leaves or in a folded leaf; in abont one week the moth appears; in greenhouses it breeds all the year and attacks chrysanthemums, geranium, cinerarias, sweet peas and other plants.

Control-Spray with arsenate of lead, $2 \mathrm{~T} / 2$ pounds to 50 gallons of water, as soon as the caterpillars appear and hit the undersides of the leaves; hand-pick the caterpillars.

\section{Tite GREenhouse White-FLy ${ }^{7}$ (Trialeurodes vaporariorum ) \\ Order-Hemiptera}

The adult insect has four pure white wings and is about I-I 6 of an inch in length; the young insects are oval, flat, and whitish and cling closely to the undersides of the leaves where they suck out the juices.

The small greenish egos attached to the undersides of the leares hatch in about eleven days and the young insects attain their growth in from 3 to 4 weeks; there are several generations each year, and the injury often becomes very severe.

Control-An all-night fumigation with hydrocyanic acid gas, I ounce of cyanide to 3500 cubic feet of space, has given good results; it is necessary to fumigate at intervals of ten days to two weeks. Spraying with soap, I pound in 6 gallons of water is of adrantage, but if the solution is applied frequently the soap should be washed from the plants occasionally by spraying with clear water, 
Tite obligue-banded leaf-Rollek ${ }^{8}$ (Archips rosaceana)

Order-Lepidoptera

The light-brown moth has three, more or less, dark-brown, broad oblipue bands on each wing; she deposits her yellowish-green eggs in patches on the leaves; they hatch in 8 to 12 days and the wreen caterpillars eat the leaves and petals and buds of the rose and become grown in 3 to 6 weeks; each caterpillar pupates for two weeks in a folded leaf; there are at least two generations a season.

Control-Hand-pick larve; spraying with arsenate of lead, 2 pounds to 50 gallons of water, has given good results where the plants were not too crowded.

\section{The rose Midge ${ }^{9}$ (Dasyncura rhodophaga) Order-Diptera}

The mosquito-like midge lays its eggs just under the sepals of the flower buds or between the leaves of the leaf buds; they hatch in 2 days and the maggots suck the sap from the petals and leaves and become grown in from 5 to 7 days; they then go into the ground and pupate in tiny silken cocoons; the whole life cycle is passed in I2 to I6 days.

Control-In latter part of October cover ground all over in rose benches with tobacco dust $\mathrm{I} / 4$ to $\mathrm{I} / 2$ inch in depth; this will kill the maggots as they try to enter ground; fumigate house every night for two weeks and then every other night for a week with nicotine paper or nico-fume; spray dirt walks with $5 \%$ kerosene emulsion.

6, 7, 8 Davis-27th Rept. I11. State Ent., p. 98.

${ }^{3}$ Sasscer and Borden-U. S. Bu. Ent., Bull. 778. 
Tine CIIRysantilemum Midge ${ }^{10}$ (Diarthromyia lıурояaca)

Order-Diptera

The chrysanthemum midge is a late comer to America and is already causing considerable injury; the small mosquito-like adult fly lays its tiny eags anong the hairs on a leaf where it hatches in about 24 hours; the maggots cause galls on the leaves, petioles, or buds; the galls may be so abundant as to cause malformation of plants, check growth, and prevent blooming:

Control-A majority of the adult flies seem to issue after midnight; therefore fumigation with nicotine should be commenced at midnight and carried on every other night for 2 or 3 weeks; spraying with nicotine sulphate, I pint to 500 pints of water with an ounce of soap to each gallon, has proven effective; an application should be made every fourth or fifth day for a month.

\section{SCAlE INSECTS AND MEALY BUGS ${ }^{11}$}

There are many species of scale insects that are injurious in greenhouses. The soft scale (Coccus hesperidum) that infests palms, croton, ficus, et al.; the hemispherical scale (Saissctia hemispherica) that occurs on palms, orchids, croton and other plants; the oleander scale (. Aspidiotus hedere), the fern scale (Hemichionaspis aspidistre) and the white pineapple scale (Diaspis bromcllice) are some of the more common ones. There are also two common species of mealy bugs that occur in greenhouses on palms, coleus, umbrella plants, et al. These are Pscudococcus adonidum and Pseudoccus citri.

Control, of scale insects-Whale-oil soap, I I0 Guyton-Jr. Ec. Ent., Vol, I2, p. I62.

11 Davis-27th Rept. III. State Ent., p. I22. 
pound to I gallon of warm water, is efficient for those species on palms, ficus and similar plants; it is unsafe on ferns; fir-tree oil, I part to 20 parts of water, is useful for the species on ferns; funigation with hydrocyanic acid gas is most effective for the mealy buss; one should consult Farmers' Bulletin SSo of the U. S. Dept. Agr.

THE RED SPIDER ${ }^{12}$ (Tetranychus telarius) Order-Acarina

This pest has been discussed at length under pests of cotton; in greenhouses it attacks the rose, violet, carnation, clematis, salvia, phlox, and other plants.

Control-Washing plants with clear water under pressure is one of the best methods of control; ivory soap, $I / 2$ pound dissolved in 6 gallons of water, is very satisfactory; nicotine sulphate plus soap is also effective; fumigation with tobacco and painting pipes with sulphur are not effective.

THE GREENHOUSE THRIPS ${ }^{13}$ (Heliothrips hamorrhoidalis)

\section{Order-Thysanoptera}

The adult is a tiny, dark-brown insect only I-24 of an inch in length; the young are whitish at first but become reddish later; they extract the juices from the leares and the leares become spotted and covered with drops of a reddish fluid excreted by the insects; the eags stuck in the leaves hatch in 8 days and the young become mature in It to 26 days.

CoNTROL-Fumigation with nicotine papers or with volatile nicotine extracts is effective if carried on at night and repeated every week or ten days; fumisation with hydrocyanic acid gas, I ounce sodium cyanide to IOOO cu. ft., for carnations for I hour at a temperature of $54^{\circ}$, has been successful;

12 Ewing-Oregon Expt. Stat, Bull. I21.

13 Russell-U. S. Bu. Ent., Circ. I5I. 
in general, I/2 ounce sodium cyanide to Iooo cu. $\mathrm{ft}$ for I hour repeated in ten days is satisfactory. SOME GREENHOUSE APHIDS ${ }^{14}$

There are two aphids, the "black-fly" (Macrosiphum sanborni) and the green aphid (Aphis rufomaculata) that are sometimes present on chrysanthemums in large numbers and are decidedly injurious; so far as known these two aphids feed only on this plant and they often occur intermixed on the same plant.

The rose is subject to the attacks of two species of plant lice, Macrosiphum rosc, and Myzus rosarmm; both of them are greenish in color and sometimes the tender terminal shoots of the plants are covered with them.

There are also two aphids that injure violets sometimes seriously; one of these, known as the "l)lack-fly" (Rhopalosiphum riole), is often abundant about the crowns of the plants; the other, known as the "green-fly" (Rhopalosiphum persi$c c)$, frequents all parts of the plant.

The carnation is often badly injured by the common green aphid (Myzus persica) which is so abundant on greenhouse plants and many outdoor plants.

Control of Greenhouse ApHids-For some aphids ivory soap, I pound to 6 gallons of water, is a simple, safe remedy: for others, nicotine sulphate, I teaspoonful to a gallon of water, with about an ounce of soap added, is efficient; fumigation with nicotine papers or some of the volatile nicotine solutions is satisfactor:y if care is taken to use the right amount for a given space and the house is tight: fumigation with hydrocyanic gas is effective if correctly done.

14 Davis-27th Rept., I11. State Ent., p. II6. 


\section{INSECTS INJURIOUS TO SHADE TREES}

\section{The elm Leaf-Beetle ${ }^{1}$ (Galerucella luteola)}

\section{Order-Coleoptera}

Introduced from Europe and first found here in I $83+$ in Baltimore; the beetle is about one-fourth of an inch long, brownish-yellow in color with a dark line along each side of its back; the adults and larvæ eat the leaves and defoliate the trees.

The full-grown beetles hibernate in cracks and crevices, especially in attics of houses, and appear in spring as the leaves are putting out; they lay their orange-colored eggs on the undersides of the leaves; these hatch in 5 or 6 days; the grulss eat the leaves and mature in I 5 to 20 days and pupate at the bases of the trees on top of the ground; in 6 to Io days the adults appear and in New York there is a second generation.

Control-Spray with arsenate of lead as trees come in full leaf for the beetles and again about 3 weeks later for the grubs; use 3 to + pounds to 50 gallons of water; the Gypsy-moth Commission sprays but once and uses 5 pounds to 50 gallons; they spray as soon as trees come into good leafage.

\section{The ELM LEAF-MINer ${ }^{2}$ (Kaliosysphinga ulmi) \\ Order-Hymenoptera}

The leaf-miner is another European insect but it works on Scotch and English elms; it is a savfly and the larve "blister" and kill the leaves; the adults are small, shining black sawflies, about oneeighth of an inch long.

1 Herrick-Cornell Univ. Expt. Stat., Bull. 333.

Felt-Bull. 20 of the N. Y. State Museum.

2 Slingerland-Cornell Univ. Expt. Stat., Bull. 233.

Herrick-Cornell Univ. Expt. Stat., Bull. 333. 
The eggs are laid in May beneath the epidermis of the leaves and the larva mine in the tissues of the leaf making large irregular mines or "blisters" in the leaves; they become mature in July and go into the ground where they make thin papery cocoons and remain in them until next spring; they then change to pupe and the flies appear in May; only one generation.

Control-Spray the leaves just as the mines begin to show, about first of June, with nicotine sulphate, I pint to Ioo gallons of water with 5 pounds of soap.

The wilte-Marked TUssock-Moth ${ }^{3}$ (Hemerocampa lencostigma)

Order-Lepidoptera. Manual, p. 3 Iо

The tussock moth is a native insect that is very injurious at times to shade-trees and fruit-trees; the larva is very striking in appearance; it is two inches long and bears four tufts or tussocks of creamy white hairs on its back with two long pencils of hairs on its head and a third on the posterior end of the abdomen.

The moth lays its eggs in whitish masses in summer on the trees; they remain here until the following spring and then hatch into the caterpillars that strip the trees of foliage; these caterpillars often migrate from tree to tree; when full-grown they make cocoons on the trees and change to pupæ; one brood a season except in extreme southeastern part of State.

Control-C Collect egg masses during fall and winter; spray trees with arsenate of lead, 3 pounds to 50 gallons; band trees with cotton in June, July, and August.

3 Howard-U. S. Dept. Agr., Far's' Bull. 99. 


\section{The fall web-worm ${ }^{4}$ (Hyphantria textor)}

\section{Order-Lepidoptera. Manual, p. 32 I}

This is a typical American species and found from Canada to Texas; it has been recorded as feeding upon I2O species of trees; the moths are white or spotted with black and conspicuous; the larve make ugly silken nests all over affected trees.

The moths lay 400 to 500 eggs in clusters on the leaves; the caterpillars feed in masses and spin webs enclosing leaves; they pupate in cocoons just below the surface of the soil or on ground under trash or about trunks of trees; farther south there are two broods, but only one in central and northern New York; the pupæ pass the winter in cocoons.

Control-Cut out nests of larvæ; spray with arsenate of lead around the nests of the larvæ.

\section{Bronze BIRCH-BORER ${ }^{5}$ (Agrilus anxins) Order-Coleoptera}

This is a small olive-bronze colored beetle about one-half an inch long that is killing so many of the white birches in New York State. It attacks the top branches first but gradually spreads to all parts of the tree. The larve bore through the sap-ivood just beneath the bark and sometimes deeper into the solid wood. The larvie pupate in cells beneath the bark and in Nay or early June the beetles make half-round exit holes in the bark and emerge. through these.

CONTROL-The only way of arresting the spread of the pest and stopping the death of healthy trees is to cut down and burn the infested ones before May first.

${ }^{4}$ Felt-Insects Affecting Park and Woodland Trees, Vol. I, p. I42.

5 Slingerland-Cornell Univ. Expt. Stat., Bull. 234. 


\section{WILLOW AND POPLAR BORER ${ }^{6}$ (Cryptorhynchus lapathi) \\ Order-Coleoptera}

This is a beetle somewhat resembling the plum curculio, but much larger, that is becoming a serious menace to poplar and willow trees both in the nursery and on the lawn. The larva bore through the wood finally causing the death of the tree. The presence of the larva is indicated by the appearance of sawdust and particles of excrement thrown outside; the yellowish eggs are laid, each in a cavity divg in the bark; it hatches in 2 or 3 weeks and the partly grown grub passes the winter just beneath the outer bark and completes its growth the next spring, the adult beetles appearing during the latter part of July; there is one generation.

Control-Apply an emulsion of carbolineum avenarius to the trunks of trees to a height of 4 or 5 feet from ground; to make emulsion, dissolve I pound of sodium carbonate in I quart of hot water and add I quart of the carbolineum; stir vigorously and take I part to 2 parts of water.

\section{HICKORY BARK-BORER ${ }^{7}$ (Scolytus quadrispinosus) Order-Coleoptera}

The adult is a small brown or black beetle about one-fifth of an inch long; the leaves wilt and twigs die in midsummer and the bark will be found full of small shotlike holes through which the beetles have emerged; it is a serious pest to hickory trees.

The beetles appear last of June to last of July; they bore in young twigs, terminal buds and green nuts; females make galleries just under bark in sapwood and lay eggs in niches along the sides; lar-

6 Matheson-Cornell Univ. Expt. Stat., Bull. $388^{\circ}$

7 Felt-Insects Affecting Park and Woodland Trecs, Vol. I, p. 275. 
vae tunnel through sapwood and kill trees; srubs pass winter nearly full grown in galleries under bark.

Control-Cut out badly infested trees and affected portions of others and burn before Jume.

THE SNOW-WHITE LINDEN MOTH ${ }^{8}$ (Ennomos subsignarius)

Order-Lepidoptera

Half a century ago this insect was a pest of shade-trees in Brooklyn and Philadelphia; became abundant again in I007, and then was injurious in forests of New York for four years; the moths are pure white and have the habit of appearing in enormous numbers around lights in cities where their appearance has been compared to snowstorms.

Eggs are laid on branches in masses of 20 to IOO or more in June and July; hatch the next spring in April and May; caterpillars strip leaves and mature in June and July and pupate in loose cocoons on leaves; moths appear from middle of June to last of July and soon deposit eggs; one brood a year.

Control-On fruit trees spray with arsenate of lead, $2 \mathrm{~T} / 2$ pounds to 50 gallons of water; no control for forest trees known.

THE BROWN-TAIL MOTH ${ }^{9}$ (Euproctis chrysorhoca) Order-Lepidoptera

Probably introduced from Holland on shipments of roses by nursery in Somerville, Mass., about I89.3; now in Massachusetts, Rhode Island, Connecticut, New Hampshire and Maine; the larve feed on pear, apple, cherry, peach, and other fruittrees and on forest-trees; the moths are pure white with a tuft of brown hairs on end of abdomen, hence name, "brown-tail" moths; the hairs of 8 Herrick-Cornell Univ. Expt. Stat., Bull. 286. 
the larve are brittle and barbed and when they strike the skin cause a nettle or rash quite serious to some people.

Eggs laid in July in masses of 200 to 400 on leaves and covered with brown hair from body of female; they hatch and the larva feed in groups on leaves until fall when they go into hibernation in hibernacula made by webbing many leaves together, at the ends of branches; in the spring they eat leaves again and become full-grown latter part of June; pupate in cocoons in crevices of bark and other nooks; moths appear in July; one generation a season.

Control-Spray with arsenate of lead for caterpillars 3 to 5 pounds to 50 gallons of water; cut out nests of larvæ during dormant period of tree.

\section{The gypsy moth ${ }^{10}$ (Porthetria dispar) \\ Order-Lepidoptera}

The gypsy moth gained a foothold by the escape of larve or eggs from breeding cages at Medford, Mass., about I869; now found in Connecticut, Rhode Island, Massachusetts, New Hampshire, and Maine; the female moth has light buff wings marked with dark, wavy lines while the male is light brown in color.

Eggs laid in clusters of 300 to 400 in July and covered with hair; they are deposited in crevices of bark, brush piles, stone-walls, etc., and hatch the next spring in May; larvæ mature last of June and first of July and pupate in various places in thin network of silk; the moths appear in July and deposit eges; only one generation a year; the food plants are almost all trees, especially apple, oak, and willows.

9,10 Rogers and Burgess-U. S. Bu. Ent., Bull. 87. 
Control-Spray trees with arsenate of lead, 3 to 5 pounds to 50 gallons of water; burlap trees for hiding places for larve and then kill the caterpillars; tanglefoot of use in catching larve; treat eggclusters with crude coal-tar creosote blackened with lampblack to tell what ones have been treated.

\section{O'THER INSEC'TS INJURIOUS TO SHADE TREES}

Pigeon horn-tail (Tremex columba).

Maple borer (Plagionotus speciosus).

Elm borer (Saperda tridentata).

Maple scale (Pulvinaria vitis).

Leopard moth (Zeuzera pyrina).

Locust borer (Cyllene robinice).

Forest-tent-caterpillar (Malacosoma disstria).

European elm scale (Gossyparia spuria).

Evergreen bagworm (Thyridoptery.x ephemeraformis).

Spruce gall louse (Chermes abietis). 


\section{INSECTS INJURIOUS TO FARM ANIMALS}

\section{SHEEP PESTS}

SHEEP BOTFLy OR HEAD MAGGoT ${ }^{1}$ (Estrus ovis)

Order-Diptera. Manual, p. 478

The adult insect is a two-winged fly that deposits living maggots in the nostrils of sheep: the maggots pass upward into the nasal sinuses; accounts record the presence of the mageots in the brain; the maggots attach themselves to the delicate membranes by means of two hooks and feed upon the mucous secretions, causing catarh and stagerers: when fullgrown the mageots are sneezed out through the nostrils and go into the ground to undergo their transformations; the flies are most active in June and July; the maggots live in the nose about ten months; the adults have no functional mouth-parts and do not feed.

Control-Plow a piece of land in pasture and harrow until fine and dusty for sheep to stand on; smear noses often in summer with equal parts of tar and grease: bore holes in a log and put salt in them after which smear edges of holes with tar and grease; no medicine will reach grubs; do not use a wire in nostrils.

$\mathrm{ITCH}_{\mathrm{OR}} \mathrm{SCAB}^{2}$ (Psoroptes communis var. ovis) Order-Acarina

Sheep scab is strictly a contagious disease and is responsible for much loss among western sheep growers, through death of animals and damage to

1 Osborn-U. S. Bu. Ent., Bull. 5, p. I02.

2 Salmon and Stiles-U. S. Bu. An. Ind., Bull. 2 I.

Imes-U. S. Dept. Agr, Far's' Bull. 7I3. 
wool; also exporters suffer loss because American live stock are prohibited from Europe.

Scab is caused by small mites that work in the skin causing the wool to fall off and producing large scabs over the body; there are four varieties of mites that work on sheep and cause scab-the mite causing the common or "body scab"; the mite causing the "head scab"; the mite causing the "foot scab"; and the mite causing the "follicular scab" affecting the eyelids.

The common or body scab is a severe itching disease and occurs most often on the backs and sides where the wool is longest; it is the worst form of the disease in this country; the mites multiply with wonderful rapidity; one female lays I 5 to 24 eggs which hatch in a few days, and in I 5 days the young become adults; in a few months a single female can produce an enormous number of progeny.

Control-When far advanced, soften the scab with some kind of grease or oil, and then apply some of the common "sheep dips"; the active ingredients in most "dips" are tobacco, arsenic and carbolic acid; each sheep will require from a puart to a gallon: use the dip at a temperature of roo degrees in summer and ro degrees warmer in winter; a simple method of treating a few sheep is to turn them on their back and pour the dip along the middle line of the venter; where large numbers are to be dipped, special tanks are made; a kerosene emulsion is also a good sheep "dip"; a second or third dipping may be necessary, as the dips do not often kill the eggs, and another brood may appear later.

$$
\begin{aligned}
& \text { THE SHEEP "TICK" } 3 \text { (Melophagus ovimus) } \\
& \text { Order-Diptera. Manual, p. } 488
\end{aligned}
$$

A curious, degraded, wingless insect belonging 3 Imes-U. S. Dept. Agr., Far's' Bull. 798. 
to the same order as the gad-flies and the common housefly; it is thus not a true tick; very common on sheep, hut seldom causes serious injury to old sheep; lambs are often worried and hindered from acquiring fat; the "ticks" cling very tenaciously to the skin and suck the blood; the egos are hatched within the body of the flies, and the magsot is nourished there until it is nearly full-grown, and is not born until it is nearly ready to change to a pupa: it is stuck to the fihers of wool; each fly produces from two to fifteen of these brown puparia, one-third as large as the mother fly; they are laid in the wool to which they adhere, and they give out the adult fly in about three weeks; the "ticks" are most numerous in the spring, cause much irritation, and hinder young lambs from making their normal growth; their whole life is spent on the sheep.

Control-Keep the pen clean; after shearing, apply any of the standard "dips" or kerosene emulsions.

THE SHEEP LOUSE (Trichodectes sphcrocephalus)

A biting louse that works at the base of the wool; not often abundant.

\section{CATTLE PESTS}

The ox warble, or BotFly ${ }^{4}$ (Hypoderma lineata) Order-Diptera. Manual, p. 478

The ox botfly is widely distributed in this country and Europe; it is found on the buffalo (Bison) here; it causes much loss by affecting the general health of animals and also hy its perforations of hides, thus lowering their value; there is a second species in this country, the European botfly (Hypoderma bovis) which is very similar in appearance and habits.

4 Hadwen-Canad. Dept. Agr., Sc. Ser., Bull. 2 I.

Hadwen and Bruce-Canad. Dept. Agr., Sc. Ser., Bu1l. 22, 
The adult flies are about one-half inch in length and bee-like in appearance; the egres are laid on the hair around the heel and on the lower part of the les, and on other parts of the body; they hatch in + to 7 days and the larve bore directly down a hair follicle and get beneath the skin; they work their way along beneath the skin to the cesophagus; from here they work down to the diaphragm, up a ril, and finally to the back beneath the skin; there the larve produce swellings or warbles and after completing their growth wriggle out and go into the ground in the spring; here they change to pupie and finally the adult fly appears; the flies seen to annoy cattle very much although they do not bite or sting; $50 \%$ of the cattle in the Mississippi Valley are affected.

Control-Apply kerosene or grease to the "warbles" in the winter, or as soon as noticed; this will close up the breathing holes of the maggots and cause their death; remove by squeezing or otherwise, the maggots from the "warbles."

\section{The HORN-FLY ${ }^{5}$ (Hamatobia serrata $=$ Lyperosia irritans)}

\section{Order-Diptera}

The horn-fly is another importation from Europe; it came to America in 1885 and landed near Philadelphia apparently; it is now distributed all over the country; the adults are alout half as large as the house-fly; they annoy cattle very much and cause a large loss to the milk supply.

The flies lay their eggs in fresh cow droppings; the maggots attain their growth there in a few days and burrow just beneath the surface of the earth and change to pulpe; the adults soon appear; the whole life cycle may be gone through in two

5 Osborn-U. S. Bu. Ent., Bull. 5, p. II4. 
weeks and there are four or five broods in a season. The adults have a habit of gathering on the bases of the horns but cause no injury at this place; the flies are common from May until frosts of autumn.

Control-Almost any greasy substance, like axle grease, fish oil, kerosene emulsion, crude petroleum, etc., applied to the afficted parts will keep the flies away for several days; where sores are formed, add a little carbolic acid to the grease or oil; tobacco powder will kill the flies if it is dusted on them; spread out or mix lime with the fresh cow droppings; spray cows with crude petroleum. Also see repellant mixtures, p. I52.

\section{SuCKING CATTLE LICE ${ }^{6}$ (Hamatopinus eury- sternus) \\ (Linognathus vituli) \\ Order-Hemiptera}

There are two species of sucking lice, the shortnosed ox louse and the long-nosed ox louse; they are apt to be abundant especially on calves and on poorly cared for and ill-fed cattle; on these they may cause injury.

The egors are attached to the hairs of the animal and the roung lice gradually develop to the adults.

Control-An infusion of stavesacre seeds seems to be the most accepted remedy. Four ounces stavesacre (Delphinium) seeds, I ounce white hellebore boiled in I gallon of water until only 2 quarts remain and applied with a brush where lice are seen; kerosene emulsion, I $5 \%$, or crude petroleum rubbed in among the hairs; 2 or 3 applications of either at an interval of one week; raw linseed oil has been recommended; it is applied with a brush but one must not rub too vigorously.

6 Imes-U. S. Dept. Agr., Far's' Bull. 909.

Lamson-Conn. (Storrs) Expt. Stat., Bull. 97. 
TIIE BITING CATTLE Louse ${ }^{\top}$ (Trichodectes scalaris) Order-Mallophaga

This species of louse is common the world over and is often very abundant; they do not seem to he as injurious as the sucking lice attributable to the fact, probably, that they do not suck l)lood; they are smaller than the sucking lice; they are generally found in more abundance in the spring of the year; at this time egos and adults are easily found.

Control-Same as for the sucking lice.

\section{SOUtherN CATtLE TICK ${ }^{8}$ (Boophilus ammulatus)}

\section{Order-Acarina}

One of the ticks, thus not a true insect. It is the carrier of Texas fever, a blood disease caused by a minute protozoan parasite working in the red blood corpuscles; the ticks drop from the cattle when full grown and lay eges, sometimes as many as 3000 among the grass; the young ticks which hatch must find their way to the cattle to live, and these young ticks will introduce the disease to healthy stock; infested Southern cattle often introduce the disease into Northern herds, but as our cold winters kill the ticks, the disease disappears unless reintroduced in Southern ticks brought north the next season.

Control-Thoroughbred Northern cattle are now taken south and there inoculated and only a mild form of the disease produced: the ticlis are now being gradually exterminated from the country by dipping infested cattle in an arsenical solution at certain intervals throughout the season.

7 Osborn-U. S. Bu. Ent., Bu11. 5, D. 209.

8 Mohler-U. S. Bu. An. Ind., Bull. 78.

Ellenberger and Chapin-U. S. Dept. Agr., Far's' Bull. I057. 


\section{PESTS OF HORSES}

BotFly ${ }^{9}$ (Gastropliilus intestinalis)

Order-Diptera. Manual, p. 477

The adults are about three-fourths of an inch long and rather light brown in color; the fly does not bite or sting yet many horses are much worried by its presence; authorities differ as to injury by the bots; they may irritate the stomach; may absorb much nutriment from the stomach contents, and cause irritation in the intestines.

The fly attaches its eggs to the hairs on the legs and shoulders of horse; eggs licked off by horse and carried to stomach where the mag"gots or "bots" attach themselves to the walls of this organ; they usually spend several months in the digestive organs; probably not more than one maggot in fifty ever reach stomach; they live in the dung during May or June, go into ground and pupate.

CONTROL-Shave off the eggs with a sharp knife or razor once in two weeks at least; kill eggs by running over them lightly with carbolic acid, 2 percent phenol.

THE THROAT BOTFLy ${ }^{10}$ (Gastrophilus masalis)

Attaches its eggs to the hairs of the lips and nostrils and to the hairs of the throat.

Control_-Same as foregoing species.

\section{HoRSEFLY OR GADFLY ${ }^{11}$ (Tabamus atratus)}

\section{Order-Diptera}

A large black fly that flies swiftly, bites fiercely and is a persistent eneny of horses and cattle; eggs have been found attached to leaves overhanging water; larvæ live in marshy ground and along

9, 10 Dove-U. S. Bu. Ent., Bull. 597.

ii Garman-Ken. Expt. Stat., Bull. I5 I. 
streams; these flies often becone abundint and injurious to cattle and horses but they do not produce "warbles" or bots.

Control-Success has been obtained by putting kerosene oil on pools of water frequented by these flies. They are killed by coming in contact with the oil. Certain repellant mixtures may be put on cattle but difficult among large herds. Nets on horses are a protection.

\section{A PEST OF HOGS}

Tine HOG LOUSE ${ }^{12}$ (Hamatopinus urius)

\section{Order-Hemiptera}

Occasionally this species appears in great numbers on swine; a full-grown louse measures onefourth inch or more in length; it is gray in color and has sucking mouthparts.

Control-Washes of dilute carbolic acid ( I to 30) or the tobacco extracts or kerosene emulsion will control these lice; a wallowing trough of cement with a film of oil on top is a very good method of control.

\section{O'THER INSECTS IXJTRIOUS TO LIVE STOCK} ale).

Turkey gnat (black-fly) (Simulium meridion-

Buffalo gnat (black-fly) (Simulium pecuarum).

Brown gad-fly (Tabanus exul).

Ear-fly (Chrysops vittatus).

Stable fly (Stomoxys calcitrans).

Screw-worm fly (Paralucilia macellaria).

Lone star tick (Amblyomma mipuncta).

REPELlANTS FOR FLIES ON LIVE STOCK

Many mixtures have been recommended for ap12 Lewis-Oklahoma Expt. Stat,, Bu1l. 72. 
plication to horses and cattle to protect them from the attacks of flies. No one of these repellants has proved entirely satisfactory because of the trouble of application, the transitory effectiveness of the material, and the possibility of injury to the animal to which the mixture has been applied.

The following mixtures are simple compounds and perhaps as effective as any in present use:

${ }^{13}$ Fish oil.................... roo parts

Oil of tar.................... 50 parts

Crude carbolic acid.............. I part

Apply with hand spray pump or with a brush.

${ }^{14}$ Fish oil .................... I gallon

Oil of $\operatorname{tar} . . \ldots \ldots \ldots \ldots \ldots \ldots \ldots \ldots, 2$ ounces

Oil of pennyroyal............... 2 ounces Kerosene ................... 1/2. pint

Apply lightly with a brush.

${ }^{15}$ Crude cotton-seed oil.............. 2 parts Pine $\operatorname{tar} \ldots \ldots \ldots \ldots \ldots \ldots \ldots$ I part

Apply at milking time with a brush.

13 Moore-South Dakota Bull. 8I, pp. 4I-42.

14 Bishop-U: S. Dept. Agr., Far's' Bull. 540.

15 Weed-Miss. Expt. Stat., Bull. 28. 


\section{EXTERNAL PARASITES OF POUITRY}

The external parasites of poultry are many in number, at least is different kinds of mites and 9 or Io different kinds of lice are parasitic on poultry. One tick and two fleas are also found as pests on domestic fowls.

\section{Chicken Mite ${ }^{1}$ (Dermanyssus gallina)}

\section{Order-Acarina}

The chicken mite can be found in almost any poultry house and often exceedingly abundant in some, especially unclean ones; it has a marked effect on egg production; will prevent hens from fattening and will drive sitting hens from nests; it causes a high mortality among young chicks and is a pernicious pest; the mouth parts are fitted for piercing and sucking and the mites suck the blood of their hosts; they are usually found on fowls only at night, for they remain hidden during the day in cracks and crevices of the perches and houses.

The mite varies in color from pale yellowish to red; it deposits small white eggs in cracks and crevices of the perches and nest boxes; these hatch in 3 or 4 davs into almost white six-legged mites that gradually grow by casting their skins until they become adults with 8 legs; the life cycle may be passed through in 9 or Io days; they increase enormously.

Control-Poultry houses should be built so that every part of them is well lighted and aired; the houses should be kept scrupulously clean; the houses

1 Herrick-Mississippi Expt. Stat, Bull. 78.

Repp-Iowa Expt. Stat., Bull. 69. 
should be built so that the perches, nest boxes, etc., may be readily removed leaving only four bare walls; spray the inside of houses with one part crude carbolic acid and three parts kerosene; sitting hens should be isolated from laying hens; a dust bath should be provided for the fowls.

HEN LICE ${ }^{2}$ (Menopon pallidum and other species) Order-Mallophaga

There are 9 or Io species of lice that infest fowls; they have biting mouth-parts and live upon scales of cast-off skin and on bits of feathers-do not suck blood; they irritate the fowls, however, by their presence and interfere with growth and egg production and are fatal to young chicks; these lice are permanent parasites and each leg ends in two sharp claws.

The lice deposit their whitish eggs or "nits" at the bases of the feathers; here they hatch and the young lice gradually grow into adults.

Control- - T'se the same measures as for the mites: dips have been recommended but they are objectionable: one of the best is made by mixing $\mathrm{I} / 2$ ounces of pure carbolic acid with $\mathrm{I}$ gallon of hot water: when cool immerse the fowl in it one minute: creolin at the rate of $2 \mathrm{I} / 2$ ounces to the gallon may be used instead; the Cornell powder is good for dusting fowls; it is made of I part crude carbolic acid, 3 parts gasoline, and enough plaster of Paris to take up the liquid; $1 / 4$ pint of acid, $3 / 4$ pint of gasoline and about $2 \mathrm{~T} / 2$ pounds of plaster will form about the right proportions. Apply the powder with a sifter or with the fingers and work it in among the feathers; sodium fluoride has

2 Herrick-Cornell Univ. Expt. Stat., Bull. 359.

Lamson and Manter-Conn. (Storrs) Expt. Stat., Bull. 86.

Bishopp and Wood-U. S. Dept. Agr., Far's' Bull. 80 . 
proven to be a very simple and effective remedy; put a "pinch" on head, one or two on back and beneath each wing and below the vent.

\section{SCALY-LEG ${ }^{3}$ (Cnemidocoptes mutans) \\ Order-Acarina}

Scaly-leg among fowls is caused by a very small mite; the discase is contagious and fatal if not controlled; the leos become covered with hard greyish crusts, the fowl becomes lame and finally malsle to walk when it will eventually die.

These minute mites live beneath the scales of the legs where a white powdery substance is formed which together with the serum forms the crust.

Control - The disease is contagious and the affected fow must he isolated; disinfect house with hot water and carbolic acid and then whitewash it; soak leg of fowl in warm water to soften the scales; then scrape them off carefully; coat with caraway oil I part and 5 parts white vaseline or with Balsam of Peru once a day.

\section{Depluming SCABies ${ }^{4}$ (Cnemidocoptes gallinc) Order-Acarina}

Fowls often pluck out their own feathers or those of their mates: the feathers often fall out of themselves, that is, they break off at the bases; the bases of the quills become filled with a white powdery substance among which the mites live; here they set up an irritation that causes the fowl to pull out its own feathers; the disease usually commences at the rump) and gradtually spreads; the head and neck often become serionsly affected; the mites are most abunclant in spring and summer; as many as ten or twelve may be found at each feather.

3 Pearl, Surface, and Curtis-Poultry Diseases and Treatment, Me. Expt. Stat., I9II. 
Control-The disease is contagious and the affected fowl should be isolated; dust the fowl with fresh Buhach; use the caraway oil, I part, and white vaseline 5 parts; Theobald rubs oil of cloves over the affected area.

\section{Pulmonary mite ${ }^{5}$ (Cytodites mudus) \\ Order-Acarina}

These mites inhabit the bronchial tubes even reaching the cavities in the pneumatic bones; the mite is readily seen with the eye; it is only when they are abundant that they cause trouble; they sometimes occur in such numbers that they close up the tubes and produce asphyxia; this mite is of consideralble size and readily seen with the naked eye; it is white and globular in form.

\section{HeN FLEA ${ }^{6}$ (Ceratophyllus gallina) \\ Order-Siphonaptera}

This hen flea is evidently not abundant in America having been found here but twice so far; it has sucking mouthparts and lives upon the blood of its host; fleas are not permanent parasites; they get on the hens to feed and when through leave them.

The female lays her white eggs in the nests chiefly, but sometimes on the floor among the droppings; the egos hatch into long slender white wormlike larve that live on the organic matter found among the cracks and crevices of the house; in about two weeks they make a silken cocoon and change to the pupa : in two to three weeks the adults appear.

Control-Same methods as advised for the control of the mites and lice.

${ }^{4}, 5$ Pearl, Surface, and Curtis-Poultry Diseases and Treatment, Me. Expt. Stat., I9I I.

${ }^{6}$ Theobald-Parasitic Diseases of Poultry. 
THe Cuban men Fuea ${ }^{\top}$ (Echidnophaga gallinaceus)

\section{Order-Siphonaptera}

The flea occurs in the Southern States and at times becomes abundant and very irritating especially to sitting hens; they attach themselves to the face, to the wattles, coml), etc., and suck the blood; they finally drop off when mature and lay their eggs among the debris in the nest.

Control-Same as for hen flea.

ChICKen TiCK ${ }^{8}$ (Argus miniatus)

Order-Acarina

Occurs in Texas in injurious numbers.

CHICKEN OR FOWT-BUG (Hamatosiphon inodorus) Order-Hemiptera

This is a bug closely allied to the bedlutg and it sometimes attacks sitting hens while on their nests.

Control-Dust fowls with fresh Buhach.

Common bedBug (Cimex lectularius)

Order-Hemiptera

Sometimes a pest in poultry houses.

${ }^{7}$ Herrick-Jour. Ec. Ent., Vol. I, p. 355.

8 Bishopp-U. S. Dept. Agr., Far's' Bull. rozo. 


\section{INSECTS INJURIOUS TO THE HOUSE- HOLD}

There are many insect pests that injure the foodstuffs, clothing, carpets, rus's, etc, of the household, and the agoregate loss caused by these insects is very large. Moreover, many of these pests are now known to be the disseminators of certain human diseases, so that they have become important from more than one point of view; the more important of these household pests are discussed in the following pages.

\section{House-Fly ( Musca domestica) \\ Order-Diptera. Manual, p. 482}

The house-fly lays its white eggs in manure, decaying vegetable material and other garbage; they hatch in 12 to 24 hours into the whitish maggots: the maggots reach maturity in 5 or 6 days and change to pupe which are enclosed in dark-brown pupraria; these rest quicty about 5 days and then the adult comes forth; the adults carry typhoid fever, cholera, tuberculosis, dysentery, and other enteric diseases.

Control-Draw out stable manure twice a week or put it in a dark closet; treat manure piles with hellebore or borax; put $1 / 2$ pound of hellebore in Io gallons of water and sprinkle it over 8 bushels ( Io cu. ft.) of manure or sprinkle ro ounces of powdered borax over 8 bushels of the manure and then wet down with 2 or 3 gallons of water; build a modern fly-tight toilet; screen whole house espe${ }_{158}$ 
cially back porch; use tanglefort paper and formaldehyde, 2 tablespoonfuls in a pint of water; use fresh Buhach.

\section{Mosouttoes (Culcr and Anopheles)}

Order-Diptera. Manual, p. 4.37

All mosquitoes lay their eggs on or in water or where water will eventually be; the common house mosefuito deposits its exos in hoat-shaped masses on water where they hatch in 24 hours; the "wigoletails" attain their growth in 6 to Io days and then transform to active pupe; the pupal stage lasts 4 to 6 days; the life cycle may be passed in two weeks in hot weather.

The malarial mosquito, Anopheles quadrimaculatus, lays its eggs singly on top of the water; they hatch in 3 days and the larve lie in a horizontal position just beneath the surface film for about if days; the life cycle lasts about 24 days.

There are four mosquitoes in the United States that carry malaria and they all belong to the genus, Anopheles.

There is also one that carries the cansative organism of yellow fever; it is found in all of the Gulf States and may occur along the Atlantic Coast as far north as New York City; the species is commonly known as Stegomvia fasciata but is now placed under the name Ä̈des argentens.

Control-Use oil on water; drain all pools of water; put fish in ponds that cannot be drained or oiled; screen houses; kill adults with Buhach; use bednets.

\section{Ants (several species)}

Order-Hymenoptera. Manual, p. 633

The little red ant, the black carpenter ant, the pavement ant, and the small black ant, are the 
species most prevalent in houses in the North. In Lotisiana, Mississippi, Texas and California, the Argentine ant is becoming a great and serions pest.

Some ants make their nests on the lawns, in the walls of the houses, etc., while others make them in old logs, decaying beams, and stumps, others under stones in the pavement, etc.

Control-Isolate food products; use sponges soaked in sweetened water; locate nests and use carbon bisulphicle: squirt lierosene in entrance holes and plug with cotton; use ant tape; use a mixture of tartar emetic I part, sugar Io parts and water to moisten well.

\section{Clothes motis (three species) \\ Order-Lepidoptera. Manual, p. 257}

There are three species of these moths in the United States but only two are common in the North; the larva of these often do serious injury hy eating holes in woolen garments and by damaging furs.

Control-Air and shake clothes frequently; use moth balls; put woolens away in tight paper sacks; use a fumigation box.

\section{Carpet beetles (two species)}

Order-Coleoptera. Manual, p. 539

There are two species of carpet beetles, the socalled "Buffalo bug" and the black carpet beetle; they deposit their eges about the edges of the carpet where they are feeding; these hatch and the hairy larva feed on the carpet.

Control-Use rugs and finished floors; trap larve with woolen cloths; spray carpets with benzine, whip and hang in the sunlight; wash floors with strong soapsuds. 


\section{FLEAS (several species)}

\section{Order-Siphonaptera. Manual, p. 490}

There are two or three species of fleas that trouble household inmates, the human flea and the cat and dog fleas; the latter are the common ones and are the ones usually causing the trouble; the human flea is more or less common in California; the cat and dog fleas lay their white eggs while the flea is on its host but the eggs drop to the floor where they hatch into long worm-like larva; these larvie live on the material found in the dirt along the cracks of the floor and about the baseboards; certain fleas disseminate disease, especially the plague.

Control-Get rid of dog or cat or wash them often in a solution of creolin 4 teaspoonfuls to a quart of water for the dog, and 3 teaspoonfuls to a quart for the cat; use rugs and finished floors; wash floors with soapsuds and spray with benzine; use flake napthaline.

\section{Cockroaches (several species)}

Order-Orthoptera. Manual, p. Io6

There are four species that cause trouble in the United States; the croton bug, the oriental roach, the American roach, and the Australian roach; they lay their eggs in a mass in a sort of brown bean-like case; they live upon all kinds of food, but often contaminate with a roachy odor more than they eat; they injure books seriously at times.

Control-Trap them; use Buhach; use borax; fumigate rooms with hydrocyanic acid gas; use insectoline; use sodium fluoride.

\section{Bedbug (Cimex lectularius)}

Order-Hemiptera. Manual, p. I40

These insects go into houses in visitors' baggage, in laundry brought in from the washerwoman's; by 
migrating from another adjoining house; they lay their eggs in the cracks of beds and multiply in great numbers; they are suspected of carrying disease germs.

Control-Use iron bedsteads; paint cracks in beds with gasoline, kerosene, or benzine: pour boiling water on the beds if not afraid of injuring varnish; fumigate with sulphur, 2 pounds to IOOO cubic feet; fumigate with hydrocyanic acid gas.

Circ. 36, Clothes Moths. U. S. Dept. Agr., Bu. of Ent.

Circ. 7I, Housefly. U. S. Dept. Agr., Bu. of Ent.

Circ. ro8, House fleas. U. S. Dept. Agr., Bu. of Ent.

Circ. 5, Carpet Beetles, U. S. Dept. Agr., Bu. of Ent.

Circ. 34, Ants. U. S. Dept. Agr., Bu. of Ent.

Circ. I3, Mosquitoes. U. S. Dept. Agr., Bu. of Ent.

Bull. 4, Household Insects. U. S. Dept. Agr., Bu. of Ent.

Far's' Bull. 679, Houseflies. U. S. Dept. Agr., Bu. of Ent.

Took, Insects Injurious to the Houschold and Annoying to Man, Glenn W. Herrick.

\section{SPRAYING SCHEDULE FOR APPLES}

\section{Dormant spray.-As the buds begin to show green}

Lime-sulphur ( $32^{\circ}$ Baumé) diluted I to 8 , for San José scale, oyster-shell scale, and blister mite. If aphids are present this application should be delayed until just as the buds are bursting; at that time the young lice are clustering on the opening buds.

"Black leaf 40" tobacco extract should be added, 3/4 pint to IOO gallons of lime-sulphur solution.

\section{Summer sprays}

(A) As the buds begin to shore pink

Lime-sulphur ( $32^{\circ}$ Baumé) diluted I to 40 , for apple scab; from 4 to 6 pounds of arsenate of lead should be added to Ioo gallons of lime-sulphur, for bud moth and case-bearers.

(B) As the last of the petals are falling

Lime-sulphur ( $32^{\circ}$ Baumé) diluted I to 40 , for apple scab; from 4 to 6 pounds of arsenate of lead should be added to IOO gallons of lime-sulphur, for codling moth. This is the most important spray for the control of the codling moth.

(C) Three weeks after the petals fall

Lime-sulphur ( $32^{\circ}$ Batmé) diluted i to 40 , for apple scab; 
from 4 to 6 pounds of arsenate of lead should be added to Ioo gallons of lime-sulphur, for codling moth.

(D) The last weck in July

Lime-sulphur $\left(32^{\circ}\right.$ Baumé) diluted i to fo, for apple scal); from 4 to 6 pounds of arsenate of lead should be added to Ioo gallons of lime-sulphur for the second brood of codling moth.

\section{SPRAYING SCIIEDULE FOR PEACHES}

Dormant spray.-Before the leaf buds szell

Lime-sulphur ( $32^{\circ}$ Batmé) diluted I-8, for San José scale and peach leaf curl. If San José scale is not to be combated, lime-sulphur ( $32^{\circ}$ Baumé) diluted I to I5, or Bordeaux 4-4-50, should be used.

\section{Summer sprays}

(A) About the time when the caly.tes, or shucks, are dropping from the young fruit

(a) Self-boiled lime-sulphur 8-8-50, with arsenate of lead, 2 pounds to 50 gallons, for scab.

As this is rather early for scab and rot, the self-boiled lime-sulphur may be omitted, using merely

(b) Arsenate of lead, 2 pounds to 50 gallons of water, for curctilio.

If the self-boiled lime-sulphur is onitted, milk of lime, made by slaking from 2 to 3 pounds of good stone lime, should be added to each 50 gallons of water. This will tend to counteract any caustic action of the arsenate of lead.

(B) Two or three weeks later, or about one month after the petals fall

(a) Self-boiled lime-sulphur 8-8-50, for scab and brown rot.

(b) Two pounds of arsenate of lead added to the preceding, for curculio.

(C) About one month before the fruit ripens

Self-boiled lime-sulphur 8-8-50, for brown rot. Arsenate of lead must not be added. 



\section{INDEX}

Acanthoscelicles obtectus... .................. 106, 130

Acilia fratria............ Ios

Adalia bipunctata........ 5

Aëdes argentet1s.......... I59

Agrilus anxius........58, I39

Agrilus ruficollis......... 85

Agrilus sinuatus.......... 58

Agromyza simplex....... 97

Alabama argillacea....... I27

Alfalfa pests............. 123

Alfalfa leaf-weevil........ I25

Alsophila pometaria....... 42

Alypia octomaculata...... 77

Amblyomma unipuncta.... I5I

Ampeloglypter sesostris ... 77

Amphicera bicandatus $=$

Schistocerus hamatus .... 77

Anarsia lineatella........ 62

Anasa tristis ........... 99

Ancylis comptana........ 82

Ania limboda........... Itz

Anopheles quadrimaculatus. I59

Anthonomus grandis...... I27

Anthonomus scutellaris.... 53

Anthonomus signatus..... 8. 8

Anthonomus quadrigibbus.. 49

Ants ................. I 50

Aplid, apple-grain ....... 40

Aphid, black ............ I36

Aphid, cabbage .......... 94

Aphid, cherry .......... 67

Aphicl, currant .......... 79

Aphid, green ............ 4T

Aphid, pea ............... I06

Aphid, peach ........... 6

Aphicl, potato .......... 8o

Aphid, rosy apple ........ to

Aphid, woolly ........... 46

Aphis avenæ $=$ Rhophalosiphum prunifolix ....... 40

Aphis brassice ........... 04

Aphis forbesi ........... $8_{3}$

Aphis gossypii ......... I00, I29

Aphis maidiradicis .... I22, I29

Aphis mali ............. 4I

Aphis malifolize......... 40

Aphis persicæ-niger ...... $6 \mathrm{I}$
Aphis pomi ........... 4I

Aphis rufomaculata ....... I36

Aphis rumicis ........... I07

Aphis setaria ........... 54

Aphis sorbi ........... 40

Apple bud-worm ........ 52

Apple curculio ........... 49

Apple leaf-roller ......... 49

Apple leafhopper ........ 52

Apple maggot .......... 44

Apple pests ............ 36

Apple seed-chalcis ....... 47

Apple tree borers ........ \& 8

Apple weevil ........... 52

Archips argyrospila $49,59,66,70$

Archips cerasivorana ..... 69

Archips obsoletana ....... $8_{3}$

Archips rosaceana

........... 52, 70, I33

Argas miniatus = Argas per-

sicus ............... 157

Argas persicts .......... I57

Argopsvilla gallinacea $=$

Echidnophaga gallinaceus. I57 Army worm ........8, II8, II9

Arsenate of lead .......II, I4

Arsenate of calcium .......II, I5

Arsenic, white .......... I I

Arsenite of lime ......... I I

Arsenite of copper ........ II

Arsenite of zinc .........II, I6

Asparagus beetles .......96, 97

Asparagus miner ........ 97

Asparagus pests ......... 96

Asphondylia miki ........ I27

Aspidiotus forbesi ....... 70

Aspidiotus hederæ ....... I.34

Aspidiotus howardi ...... 59

Aspidiotus juglans-regix.... 8I

Aspidiotus ostreaformis.... 54

Aspidiotus perniciosus

$\cdots \ldots \ldots .25,34,56,59,8$ r

Aspidiotus nvae ......... 77

Ataxia crypta .......... I29

Aulacaspis pentagona ..... 66

Atrlacaspis rosi ......... S7

Autographa brassicæ ..... 95

Autographa falcigera...... I07 
Autographa gamma-californica ............ I27

Baits, poison .......... I7

Barium stulphur ......... 2x

Bean pests ............ I0

Bean leaf-beetle .......... Ion

Bean weevil ............ rof

Bedbug .............. I I I

Bees ................ 4

Beet leaf-miner ......... I0,3

Beet pests ............ IO?

Bembecia marginata ...... $\xi_{i_{1}}$

Billbugs ............. I 20

Birch borer ........... I $3^{(1)}$

Birds ............... "1)

Biting insects ......... s

Blackberry pests ........ $\$_{3}$

Black death ............ it

Black-leaf-40 ......... 20

Blastophaga ...........

Blister beetle ........... ing, in

Blister-mite ......25,48, 54

Blissus leticopterus .... II5, I23

lioll-weeril ............ 4, т 27

Bollworm, cotton ........ i i...

Bollworm, pink cotton .... I 2

Books .................

Boophilus annulatus ...... I f

Bordeaux mixture ....... 3.3

Borer, flat-headed ........ it

Borer, round-headed ...... 3.

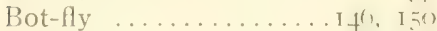

Braconids .............. (1

Bronze birch-borer ....... I, I, in

Brown-tail moth ...4, 8, 52, If I

Bruces measuring-worm ... s:

Bruchophagus funcbris.... I 25

Bruchus chinensis ....... 107

Bruchus obtectus ......... Io'

Bruchus pisorum = Mylabrus pisorum ........... 10

Bruchus quadrimaculatus... In

"IB.T.S." ............ 26

Incculatrix pomifoliella ... t5

Pud moth ............. 3e

Buffalo tree-hopper ...... 5

Bug death ............ if

Bumblehees ........... 5

Pyturus nuicolor ........ s s

Cabhage aphid .......... nt

Caluhase hut........... 05

Cabbage looper ......... of

Cabbage insects ........ 02
Cabbage root-maggot $\ldots . .992$

Cabbage worm, imported .. 94

Calandra granaria ....... I30

Calandra oryzæ......... I30

Calendar, spray ........ 62,163

Caliroa cerasi............ 56

Calosoma sycophanta ..... Io

(ankir-lkorm, fitl .....8, 42

Canker-worm, spring .....8, 42

Carabidx ............. 5

Carbolic acid emulsion ... I9, 23

Carbon bisulphide ........ 27

Carpet heetles ........... I60

Carpocapsa pomonella ...36, 59

Carrot pests ........... I08

Carrot rust-fly ........... 107

Case-bearers ........... 39

Cassida bivittata ......... 9I

Cassida nigripes ......... 92

Cattle lice ............. I 48

Cattle pests ............. I46

Cattle tick ............. I49

Vecidomyia destructor $=\mathrm{Ma}$ -

yetiola destructor ........ I I 4

Celery pests ........... 107

Cephus pygmxus ......... II9

Ceratophyllus gallina .... I56

Cereal insects ............ II 4

Ceresa bubalus .......... 5 I

Cerotonia trifurcata ...... I05

Centorlinnchus rapae ..... 96

Chretocnema confinis ..... 90

Chalcis-flies ........... 6

Chermes abietis ......... It3

Cherry fruit-flies ....... 68

Cherry leaf-miner ....... 69

Cherry leaf-roller ........ 69

Cherry louse, black ...... 67

Cherry insects ..........67 67

Chicken bug ........... I57

Chicken lice ........... I5t

Chicken mite ............ I5.3

Chicken tick ............ I57

Chilocorus bivulnerus ..... 5

Chinch bug …3. 8, 9, II5, 123

Chionaspis furfura ...... 57

Chloridia virescens ....... II 3

Chrysanthemum midge .... I I34

Chrysobothris femorata ... 37

Chrysops vittatus ......... I5I

Cimex lectularius ...... I57, I6I

Cigar case-bearer ......... 39

Clothes moths ........... I60

Clover flower-midge ....... I24

Clover hay-worm ........ I26 
Clover leaf-beetle ......... I24

Clover pests ..........9, I23

Clover root-borer ......... I2,

Clover seed-chalcis ........ I25

Clover seed-caterpillar ..... 126

Cnemidocoptes gallina .... I55

Cnemidocoptes mutans .... I55

Coccus hesperidum ....... I34

Cochineal ............. 4

Cockroaches ........... I6

Codling moth ..3, 8, 36, 59, 67

Coleophora fletcherella .... 39

Coleophora malivorella .... 39

Colcoptera ............ 7

Colorado potato beetle .... 88

Conotrachelus cratregi ..... 66

Conotrachelus nenuphar .... 52

Contact substances ...... I9

Contarinia johnsoni ...... 76

Contarinia pyrivora ...... 57

Contarinia tritici ......... II 5

Control, artificial methods of io

Control, natural methods of 9

Coptocycla bicolor ....... 92

Corn pests ...........9, II9

Cornborer, European ..... I22

Corn root-aphid ......... I22

Cotton-boll weevil .......9, 12-

Cutton pests .......... I 27

(rambus sps .......... 120

Craponius inequalis ..... 77

Crioceris aswarasi ....... of

Crioceris duodecimpunctata. 97

Cryptorhynchus lapathi .... I I0

Cucumber beetle ........8, 98

Cucumber pests ......... 98

Culex pipiens ........... I50

Curculio, apple ......... 49

Curculio, plum ......... 52

Currant aphid ............. 79

Currant moth-borer ...... 79

Currant pests ........... 78

Currant stem-girdler ..... 78

Currant worm, imported ... 78

Cutworms ......92, 93, I02, I20

Cylas formicarius ........ 91

Cyanide, sodium ........ 27

Cyllene robinia .......... I43

Cytodites nudus .......... I56

Dasynettra legtminicola .... I 24

Dasyneura rhodophaga .... I I33

Dasyneura trifolii ........ I26

1)atana ministra ....... 5 I

Depluming scabies ...... I55
Depressaria lieracliana ..... I

Dermanyssus gallina ..... 153

Desmia funeralis ........ ji

Diabrotica longicornis ..... 1 1-3

Diabrotica 12-punctata .... $1(x)$

Diabrotica vittata ......... 心

Diaphania hyalinata...... I00

Diaphania nitidalis ......

Diarthromyia hypogra....$\quad$ I.3.

Diaspsis bromalliæe........ I, 3 -

Dicyphus minimus ....... 11,3

Diplosis pyrivora $=$ Contarinia pyrivia ......... 5

Diplosis tritici $=$ Contarinia tritici ............. I15

l)iptera ............

Disonycha xanthomelana .. Iot

1) usting ............ 30

Dysdercus suturellus ...... 1

Eccoptogaster rugulosus =

Scolytus rugulosus ..... 6

Echidnophaga gallinaceus... I57

Elm leaf-beetle ........... I.37

Elm leaf-miner ......... 1.37

Empoasca mali ..........

Fimpria frasaric ....... \$3

Emulsions of oils .........

Enarmonia interstinctana . . I

Ennomos subsignarius .... If I

Entomology ............ I

Ephestia kuchniella ...... I,30

Ficalla vittata ......... S sis

Epilachna borealis ....... Iou

Epilachna corrupta ....... I07

fipitrix cucumeris ....... हs

Fpitrix fuscula ......... ()

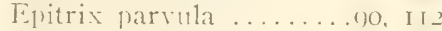

Epochra canadensis ....... SI

Erannis tiliaria ........... 52

Eriophyes pyri ........48, it

Eriosoma lanigera ........ ti

Eulecanium armeniacum ... is

Euproctis chrysorrhoea ..52, I4 I

Euryms eurytheme ...... I I27

Entettix tenella ......... no

Euthrips pyri .......... $5 x^{2}$

Euzophera semifuneralis ... 54

Evergestis rimosalis ...... ix

Exartema malanım ...... 고

Fall web-worm .......5.50, I.37

Fertilizers, commercial .... ()

Fever, typhoid ......... I 5 
Fever, yellow ......... I59

Fidia viticida ........... 72

Fig, Smyrna .......... 5

Flat-headed borer ....... 37

Fleas ................ I6r

Fleas, hen .......... I56, I57

Flea-beetles ..........96, 102

Flycatchers ............. IO

Formaldehyde.......... 28

Fruit-tree bark-beetle ..... 6I

Fruit-tree leaf-roller ..... 49

Fruit worms, green ...... 48

Fumigating substances .... 27

Gad-fly ............... I50

Galerucella luteola ....... I37

Gasoline torch ......... 29

Gastrophilus intestinalis ... I50

Gastrophilus nasalis ...... I50

Gortyna immanis ......... ro9

Gossyparia spuria ......... I43

Grain insects............ I30

Grape berry-moth ....... 75

Grape blossom-midge ..... 76

Grape insects .......... 7

Grape leaf hopper....... 74

Grape leaf-folder ........ 76

Grape phylloxera ......... 7 r

Grape root-worm ........ 72

Grape-vine flea-bectle ..... 73

Grasshoppers ........8, i Is

Green aphid ............ 4I

Green fruit worms........ 48

Greenhouse pests ......... I3I

Gymnonychus appendiculatus 81

Gypsy-moth ......4, 8, 52, I42

Hrematobia serrata ....... I47

Hrematopinus eurysternus . I48

Hamatopints urius ....... I5 I

Hæmatopinus vituli ........ I48

Hamatosiphon inodorus ... I57

IJaltica chalybea ......... 73

Harrisina americana ...... 77

Hartigia abdominalis ..... 87

llawks ................ 9

Heat ................ 28

Heliophila tnipuncta ... I I8, I I9

Ifeliothis olsoleta.........

...........103, I13, I2I, I28

Heliothrips hæmorrhoidalis. I35

Hellebore ........... II, I7

Hellula undalis ......... 96

Hemerocampa leucostigma
Hemichionaspis aspidistræ.. I34

Hemiptera ............ 7

Hen flea ............. 156, I57

Hessian fly...........3, 9, II4

Heterocordylus malinus .... 47

Hickory bark-borer ....... 140

Hippodamia convergens....5, I0

Hog louse ............ I5I

Holcocera maligemmella... 52

Honey .............. 4

Hop merchants .......... I I I

Hop-plant borer........... Iog

Hop-plant louse.......... Io9

Hop-vine snout-moth....... I Io

Hoplocampa cookei...... 70

Horn-fly .............. I.47

Horse pests ........... I50

Hose ............... 33

House-fly ............. 158

Household insects ........ I58

Hyalopterus arundinis ..... 54

Hydrocyanic acid gas ..... 27

Hylastinus obscurus ...... I23

Hylemyia antiqua ........ IOI

Hymenoptera ..........6, 7

Hypena humuli ......... I Io

Hypera punctata $=$ Phytono-

mus punctata ........... I24

Hyphantria textor ......50, I39

Hypoderma lineata ....... I46

Hypsopygia costalis ...... I 26

Ichneumon flies ........ 6

Insect parasites ......... 5

Insects, number of........ 7

Insecticides, contact ....... I8, I9

Insecticides, poison ....... I I

Isosoma grande ......... II7

Isosoma tritici ........... II7

Itch, sheep ........... I44

Janus integer .......... 78

Kaliosysphinga ulmi ...... I I37

Kerosene emulsion ....... 22

I.achnosterna sps ........ si

Ladybird beetles ......... 5

Languria mozardi ........ I 26

Lanterns ............ 29

Laphygma exigua ........ I05

Laphygma frugiperda ..... 123

Lasioderma serricorne ..... II 3

Laspeyresia molesta...... $6_{5}$ 
Laws, insecticide and quarantine ................

Leaf-bug, 4 -lined .........

Leaf-crumpler .......... 52

Leafhoppers ........... 8

Leaf-roller ..........49, 52

Leaf-roller, oblique-banded. 133

Leaf-tier, greenhouse ..... I3I

Lecanium corni ........ 53

Lecanium nigrofasciatum... 63

Lepidoptera ........... 7

Lepidosaphes ulmi ........ 45

Leptinotarsa io-lineata ..... 88

Leucania unipuncta - Heliophila umipuncta ....II8, IIS

Lice, cattle .............. I48

Lice, poultry ............. I54

Ligyrus gibbosus ......... I08

Lime-sulphur......... I9, 23, 25

Lime-tree span-worm...... 52

Linden moth............ I4I

Linognathus vituli ....... I48

Literature ............. 6

London purple ...........II, I7

Losses by insects.........2, 3

Loxostege sticticalis ...... IO5

Lycia cognataria .......... 81

Lygidea mendax ......... 47

Lygus communis........ 59

Lygus pratensis .......64, I08

Lyperosia irritans - Hæmatobia serrata ......... I47

Macrodactylus subspinosus . 73

Macrosiphum pisi ........ I06

Macrosiphum rosæ........ I36

Macrosiphum sanborni ..... I36

Macrosiphum solanifolii ... 89

Magdalis anescens ....... 52

Malacosoma americana ...43, 66

Malacosoma disstria ....43, I43

Malaria ............. 3

Mamestra trifolii ......... I05

Mayetiola destructor $=$ Cecidomyia destructor........ II4

Mealy bugs............. I34

Melanoplus atlanis........ I I8

Melanoplus bivittatus ....... I I8

Melanoplus differentialis.... I I 8

Melanoplus femur-rubrum.. II 8

Melittia satyriniformis..... 99

Melon pests ............ 99

Melon louse ............. I00

Melophagus ovinus ....... I45

Menopon pallidum ....... 154
Meromyza americana ...... II6

Metallus rubi.......... 87

Mineola indigenella ...... 52

Miscible oils ............. 22

Monophadnus rubi ........ St

Mosquitoes ............3, I59

Moth, clothes .......... I60

Musca domestica ......... 158

Murgantia histrionica ..... 95

Mylabrus (Bruchus) piso-

rum ............. 105, 130

Myzus cerasi ........... 67

Myzus mahaleb ......... 54

Myzus persica...6.63, 104, I36

Myzus ribis ........... 79

Myzus rosarum ......... 136

Nectarophora avenæ..... I I9

Nepticula slingerlandella ... 54

Neurotoma inconspicua.... 54

Novius cardinalis .......... ro

Nozzles ............. 32

Nuthatches ............ IO

Oberea bimaculata ........ 83

Oecanthus nigricornis ...77, 84

Oestrus ovis ............ I 4

Oils ................ I9, 2I

Onion maggot .......... ror

Onion thrips ........... IOI

Orioles ................ I0

Orthoptera ........... 7

Otiorhynchus ovatus ..... 83

Owl ............... 9

Ox-warble .............. It6

Oxyptilus periscelidactylus.. 77

Oyster-shell bark-louse.... 45

Pachymerus chinensis ..... 107

Pachymerus quadrimaculatus I07

Pachynematus extensicornis II9

Paleacrita vernata ....... 42

Palmer-worm ........... 5I

Pamphilius persicus....... 66

Papaipema nitela ......... I2.3

Papilio polyxenes ...... I07, I08

Paracalocoris hawleyi ..... I I

Paragrene ............ II

Paralucilia macellaria $=$

Compsomyia macellaria .. I5I

Parasitic insects ......... 5, Io

Paris green .........II, I2, I3

Parsnip pests ............ 108

Pea aphid ............ 106

Pea weevil ...........9, 105 
Peach aphid, black ....... 6I

Peach aphid, green ...... 63

Peach insects ........... 59

Peach lecanitum .......... 63

Peach moth, oriental...... 65

Peach-tree bark-beetle..... 62

Peach-tree borer ........8, 60

Peach twig-borer.......... 62

Pear blight beetle........ 59

Pear borer, sinuate........ 58

Pear insects ............ 5t

Pear-leaf blister-mite....48, 54

Pear midge............ 57

Pear psylla ............ 55

Pear slug ............ 56

Pear thrips ............ 58

Pectinophora gossypiella... I 28

Pegomya hyoscyami ....... I03

Pemphigus betæ ......... I05

Phlegethontius quinquemaculata ............... I02

Phlegethontius sexta ...... II 2

Phlœotribus liminaris ..... 62

Phorbia brassica......... 92

Phorbia fusiceps ....... I07, I23

Phorbia rubivora ........ 85

Phoroclon humuli ......... rog

Phthorimea operculella..g0, II

Phylctienia ferrugalis... I08, I3I

Phyllophaga .........8 I, I20

Phylloxera vastatrix....... 7 $\mathrm{I}$

Phytonomus posticus ...... 125

Pistol case-bearer ....... 39

Phytonomus nigrirostris.... I27

Plagionotus speciosus..... I I 43

Plodia interpunctella ...... I, 30

Plum curculio .....9.9, 51, 52, 65

Plum gouger ........... 53

Plum insects .......... 52

Plum scale ............. 53

Plutella maculipennis ..... 96

Pocilocapsus lineatus .... 80

Poisinns ............... II

Polychrosis vitcana ...... 75

Polygonia comma ........ III

Polygonia interrogationis... II I

Pontia protodice .......... 96

Pontia rapæe............ 94

Poplar borer ........... I40

Porthetria dispar ......52, I42

Potato aphid .......... 89

Potato flea-beetle........... 8s

Potato insects ........... 88

Potato stalk-borer........ 90

Pot1ltry pests ........... I53
Predaceous insects ........ I0

Proctotrypid-flies ......... 6

Profenusa collaris ....... 69

Pseudanthonomus cratagi.. 52

Pseudococcus adonidum .... I34

Pseudococcus citri ....... I34

Psendococcus trifolii ...... I27

Psila rosae ............. I07

Psoroptes communis ...... I44

Psylla pyricola .......... 55

Psylliodes punctulata ...... I I I

Pteronus ribesii ......... 78

Pterophorus monodactylus.. 92

Pulmonary mite .......... I56

Pulvinaria vitis ........77, I43

Pumps .............. 32

Pyrausta nubilalis ........ I22

Pyrethrum ............ 18, 19

Quince curculio ......... 66

Rachela bruceata ........ 52

Raspberry cane-borer .....8, 83

Rasplerry cane-maggot.... 85

Paspberry root-borer ..... 86

Raspberry saw-fly ........ 84

Redbugs. apple ......... 47

Redbug, hop ............ III

Red-humped apple-worm... 50

Red-necked cane-borer .... 85

Red spider.....87, I I I, I 29, I35

Repellants for stock........ I5 I

Rhagoletis cingulata ...... 68

Rhagoletis fausta ........ 68

Rlagoletis ribicola ......... SI

Rhagoletis pomonella ..... 44

Rhopalosiphum persicx..... I36

Phopalosiphum prunifolix.. 40

Rhopalosiphum violæ ...... I36

Ribbed cocoon-maker ..... 45

Rose chafer........... 73

Rose midge ............ I33

Round-headed borer .... 37

San José scale

$\ldots \ldots \ldots 3,4,25,56,59,66$

Sanninoidea exitiosa ..... 60

Saperda candida ......... 37

Saperda tridentata ....... I 43

Saissetia hemispherica .... I I34

Scab, sheep ........... It+

Scale insects, greenhouse... I34

Scaly-leg ............. I55

Schistocerus hamatus $=\mathrm{Am}-$ phicerus bicaudatus...... 77 
S.hizura concinna ....... 50

Scolytus quadrispinosus.... I40

Scolytus rugulosus $=$ Eccoptogaster rugulosus ...... 6r

Scurfy bark-louse........ 57

Semasia nigricana ........ I07

Sesia rutilans ........... 83

Sesia tipuliformis ........ 79

Shade-tree pests ......... 137

Sheep louse ............ I46

Sheep pests ............ I44

Sheep tick ............. I 45

Shellac................ 4

Shot-hole borer........... 8

Silk-worms ........... 4

Silvanus surinamensis...... I30

Simulium meridionale..... I5I

Simulium pecuarum ...... I5I

Sitones flavescens ........ I27

Sitones hispidulus ....... 127

Sitotroga cerealella ....... I30

Slug-shot ............. I6

Soaps ...............19, 20

Sodium sulphur ......... 26

Soluble sulphur .......... 26

Sphenophorus callosus .... I20

Sphenophorus æqualis ..... I2I

Sphenophorus parvulus .... I2I

Spinach flea-beetle......... I04

Spinach pests ............ I03

Spraying, history of...... 30

Spraying schedules......162, I63

Spray-sulphur .......... 26

Squash bug ........... 99

Squash-vine borer........ 99

Stegomyia fasciata........ I59

Stock, repellants for........ I5I

Stomoxys calcitrans ....... I5 I

Stored grain pests......... I30

Strawberry insects ....... 8I

Strawberry leaf-roller..... 82

Strawberry weevil ....... 82

Sucking insects ......... 8

Sulphur, soluble........ 26

Swallows .............. Io

Sweet potato flea-beetle ... 90

Synanthedon picipes ...... 66

Syntomaspis druparum..... 47

Syrphidze ............ 5

Tahanus atratus ......... I50

Tahanus exul ............ I5 I

Tachinide ............. 6

Tanglefoot ........... 29
Tarnished plant-bug ...... 64

Tarnished plant-bug, false.. 59

Tent caterpillars.........8; 43

Tetranychus telarius ......

..........87, III, I29, I35

Thrips tabaci ........... IOI

Thrips, greenhouse ....... 135

Thyridopteryx ephemeraformis

Tipuli............... I43

Tipnida .............. I I9

Tischeria malifoliella ..... 49

Titmice .............. I0

Tmetocera ocellana ........ 38

Tobacco flea-beetle ....... II 2

Tobacco pests............ I I 2

Tobacco .............. I9

Tobacco paper............ 28

Tomato pests...........8, 102

Torch, gasoline.......... 29

Tower ............... 33

Toxoptera graminum ...... II

Trap lanterns ........... 29

Tree-cricket, striped ...... 84

Treeleim .............. 30

Tremex columba......... I 43

Trialeurodes vaporariorum. 132

Trichobaris trinotata ..... 90

Trichodectes scalaris ...... I 49

Trichodectes spherocephalus I 46

Tritoxa flexa ............ I0 2

Trumpet leaf-miner...... 49

Tussock moth.........44, 138

Twig girdler.. ......... 8

Tyloderma fragariae ...... 83

Typhlocyba comes ....... 74

Typhoid .............. 2

Typophorus canellus ...... 83

Vireos ............... I0

Warblers ............. то

Wax ............... 4

Webworm sod ........... I20

Wheat insects ............ II4

Wheat joint-worm......... II7

Wheat midge ............. II

Wheat-stem maggot ....... II6

Wheat straw-worm........ II7

White-fly ............. I32

White grubs ........9, 8 i, 120

Willow-horer ........... I40

Wire worms.......... i if, I I0

Woodpeckers ........... no

Woolly-aphid ............ 46

Wren .............. in 
Xyleborus dispar ......... 59 Yellow-necked caterpillars... 5I Xylina antennata ........48, 59 Ypsolophus ligulellus ...... 51

Xylina laticinerea ......... 48 Zetuzera pyrina $\ldots \ldots \ldots$..... I 43 



LIBRARY OF CONGRESS

|||||||||||||||||||||||||||||||||||||||||||||||

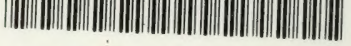

00008880104 